\title{
Properties of High-Temperature
}

\section{Ceramics and Cermets}

Elasticity and Density at Room Temperature

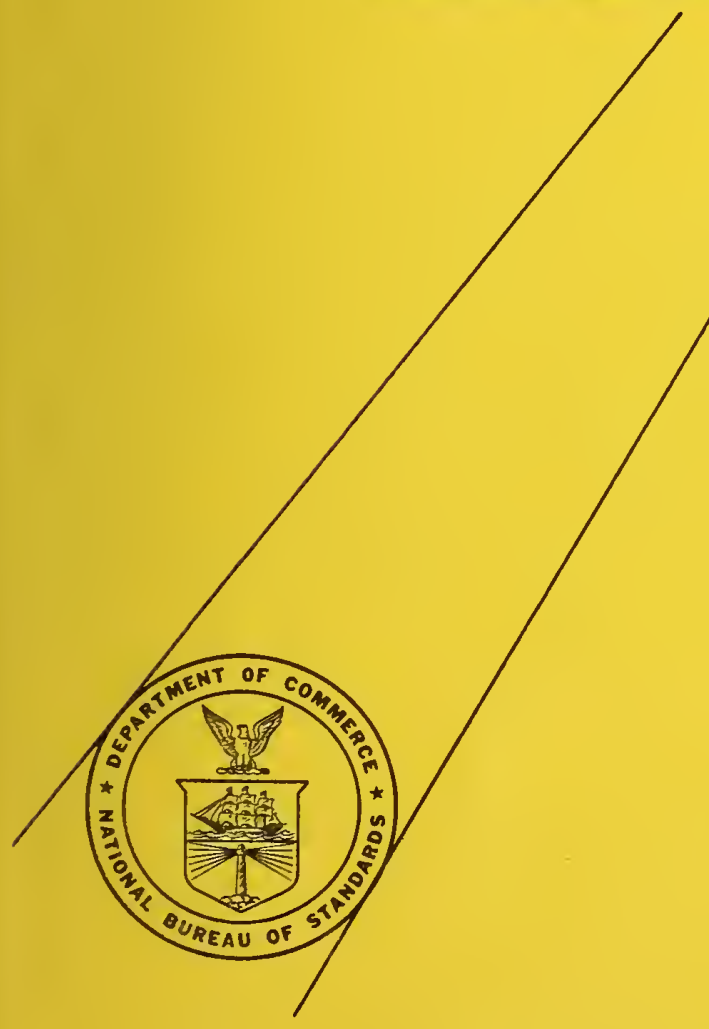

\section{U.S. DEPARTMENT OF COMMERCE NATIONAL BUREAU OF STANDARDS}




\section{THE NATIONAL BUREAU OF STANDARDS}

\section{Functions and Activities}

The functions of the National Bureau of Standards are set forth in the Act of Congress, March 3, 1901, as amended by Congress in Public Law 619, 1950. These include the development and maintenance of the national standards of measurement and the provision of means and methods for making measurements consistent with these standards; the determination of physical constants and properties of materials; the development of methods and instruments for testing materials devices, and structures; advisory services to government agencies on scientific and technical problems; invention and development of devices to serve special nceds of the Government; and the development of standard practices, codes, and specifications. The work includes basic and applied research, development, engineering, instrumentation, testing, evaluation, calibration services, and various consultation and information services. Research projects are also performed for other government agencies when the work relates to and supplements the basic program of the Bureau or when the Bureau's unique competence is required. The scope of activities is suggested by the listing of divisions and sections on the inside of the back cover.

\section{Publications}

The results of the Bureau's work take the form of either actual equipment and devices or published papers. These papers appear either in the Bureau's own series of publications or in the journals of professional and scientific societies. The Bureau itself publishes three periodicals available from the Government Printing Office: The Journal of Research, published in four separate sections, presents complete scientific and technical papers; the Technical News Bulletin presents summary and preliminary reports on work in progress; and Basic Radio Propagation Predictions provides data for determining the best frequencies to use for radio communications throughout the world. There are also five series of nonperiodical publications: Monographs, Applied Mathematics Series, Handbooks, Miscellaneous Publications, and Technical Notes.

Information on the Bureau's publications can be found in NBS Circular 460, Publications of the National Bureau of Standards (\$1.25) and its Supplement (\$1.50), available from the Superintendent of Documents, Government Printing Office, Washington 25, D.C. 
UNITED STATES DEPARTMENT OF COMMERCE • Frederick H. Mueller, Secretary

NATIONAL BUREAU OF STANDARDS - A. v. Astin, Director

\section{Properties of High-Temperature Ceramics and Cermets}

\section{Elasticity and Density at Room Temperature}

S. M. Lang

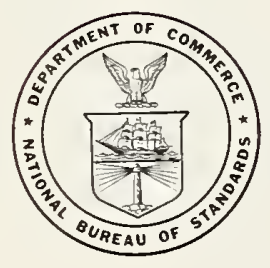

National Bureau of Standards Monograph 6

Issued March 1, 1960 


\section{Contents}

1. Introduction .........

2. Materials and procedure

2.1. Materials

2.2. Preparation of specimens

2.3. Elastic moduli

2.4. Density

2.5. Precision

2.6. Statistical treatment

3. Results and discussion

3.1. Presentation of data

3.2. Results for different materials

a. Aluminum oxide $-\mathrm{Al}_{2} \mathrm{O}_{3} \ldots \ldots$

b. Ruby alumina $-\mathrm{Al}_{2} \mathrm{O}_{3}+\mathrm{Cr}_{2} \mathrm{O}_{3}$

c. Magnesium oxide- $\mathrm{MgO}$.

d. Mullite $-3 \mathrm{Al}_{2} \mathrm{O}_{3} \cdot 2 \mathrm{SiO}_{2}$

e. Mullite $+\mathrm{ZrO}_{2}$

f. Spinel- $\mathrm{MgO} \cdot \mathrm{Al}_{2} \mathrm{O}_{3}$

g. Thorium dioxide $-\mathrm{ThO}_{2}$

h. Uranium dioxide-- $\mathrm{UO}_{2}$

i. Stabilized zirconia- $-\mathrm{ZrO}_{2}+\mathrm{CaO}$

j. Alumina + chromium- $\mathrm{Al}_{2} \mathrm{O}_{3}+\mathrm{Cr}$ -

$\mathrm{k}$. Ni-bonded titanium carbide- $\mathrm{TiC}+\mathrm{Ni}$

l. Boron carbide $-\mathrm{B}_{4} \mathrm{C}$

m. Boron carbide + titanium diboride $-\mathrm{B}_{4} \mathrm{C}+\mathrm{TiB}_{2 \ldots} \ldots$

11. Silicon carbide $\mathrm{SiC}_{\ldots} \ldots \ldots$

o. Silicon carbide + boron carbide $-\mathrm{SiC}+\mathrm{B}_{4} \mathrm{C}_{\ldots}$

p. Zirconium carbide-ZrC

q. Zirconium diboride $\mathrm{ZrB}_{2 \ldots}$

r. Molybdenum disilicide-MoSi $-\ldots$

s. Nickel aluminide-NiAl

3.3. Discussion

Appendix I. Statistical treatment of data $\ldots$

Appendix II. Tabular information 16

4. References ................................................. 45 


\title{
Properties of High-Temperature Ceramics and Cermets
}

\author{
Elasticity and Density at Room Temperature ${ }^{1}$
}

\begin{abstract}
S. M. Lang ${ }^{2}$
In order to provide some of the basic data necessary for the effective utilization of ceramies and cermets in various high-temperature applications, a specimen "bank" of such materials, mainly commercially fabricated, was established for the measurement of physical properties and constants. This Monograph describes: (1) The materials and some of their fabrication data; (2) bulk densities; (3) theoretical densities; and (4) the dynamic roomtemperature elastic constants. Data are given for 46 sets of specimens, representing 20 different materials; these include oxides, carbides, borides, cermets, and an intermetallic compound. A statistical evaluation was used for analyzing the data.

Results of the room-temperature measurements show that: (1) Significant variations are common both in the specimens of one group and from group to group of specimens prepared of the same material; (2) the largest variations occur for specimens formed by hotpressing, although average values are higher for hot-pressed specimens; and (3) measurements of the dynamic elastic constants by the sonic method are more sensitive as indicators of homogeneity and group uniformity than bulk-density measurements.
\end{abstract}

\section{Introduction}

Recent outstanding advances in the field of jet, rocket, and atomic-powered heat engines have strongly stimulated an accompanying development in high-temperature ceramic and cermet materials to withstand the high temperatures and corrosive atmospheres involved. The new ceramics have been well described by E. J. Runck $[1]^{3}$ who states that they are commercially produced by "radical departure from orthodox processes and materials", being "ceramic bodies . . . that possess no silica or clay in their structure. The coarse nonplastic portions of these new refractories have high purity and are processed at high temperatures, even up to fusion . ... The mixtures are compacted and fired ... usually above $1,600^{\circ} \mathrm{C}$. In firing, these materials do not form glassy bonds, but sinter or recrystallize by solid reactions."

Designers have been severely handicapped by a lack of sufficient data for the high-temperature ceramics and, in addition, the available data have not always been consistent [2]. This lack of consistency could result from differences in experimental conditions, or could be a real variation of properties of nominally the same material caused by uncontrolled differences in fabrication or batch composition. To fill the critical need for more complete and reliable engineering data for these ceramic materials, a "bank" of these products

\footnotetext{
1 Financial support for this investigation was supplied by the Division of Research of the U.S. Atomic Energy Commissicn.

${ }^{2}$ Present address, Owens-Illinois Technical Center. Toledo, Ohio. Since Mr. Lang's departure from NBS, this paper has heen revised by M. D. Burdick and S. Spinner.

Figures in brackets indicate the literature references at the end of this Monograph.
}

has been established. This bank contains samples from the leading manufacturers as well as some fabricated at the National Bureau of Standards. Also included are a number of cermets. These are metal-ceramic combinations designed for use at elevated temperatures.

The long-range goal of the investigation is to supply reliable engineering data for these new classes of materials. The properties to be investigated include mechanical strength, elastic and anelastic characteristics, the temperature dependence of these properties, and thermal properties generally. Since all these properties will be determined on the same set of specimens by the same test procedure, valid comparisons will then be possible.

The particular purposes of the present investigation were: (1) To determine the room-temperature elastic properties by a dynamic (sonic) method; (2) to determine both the bulk and theoretical densities; (3) to evaluate from a statistical treatment of the data the variability of fabrication of the different types of materials, using the above-determined elastic and bulkdensity data; and (4) to compare measurements of the elastic properties and densities for their usefulness as indicators of significant variations in fabrication.

Density and elastic properties were determined first because, in addition to being important properties in themselves, the experimental method for their determination is nondestructive. It thus becomes possible to perform further measurements of other properties without diminishing the number of available specimens. 
The present paper contains detailed descriptions of the methods used in calculating both the elastic constants and the statistical parameters. These detailed descriptions have been included for two reasons: (1) To leave no doubt as to the exact procedure, and (2) to act as a guide to other workers who might wish to make similar determinations.

\section{Materials and Procedure}

\subsection{Materials}

A complete list of the materials along with pertinent fabrication data is given in table 1 (appendix II). Most of these materials are commercially available; some are experimental (at the time of this investigation) including all those from source G. Some additional information concerning these materials that could not be listed in table 1 conveniently is included under results.

\subsection{Preparation of Specimens}

A convenient size and shape of specimen for the elastic modulus measurements, and one that was used whenever possible, was a rectangular prism 6 in. by $1 / 2$ in. by $1 / 4$ in. However, all of the specimens that were fabricated by the hot-pressing technique were supplied as approximately 3-in. long by 1/2-in. wide by 1/4-in. thick bars, rather than 6-in. long bars, because the shorter specimens could be made denser and with greater uniformity. In order to achieve this with available equipment, the blanks were hot-pressed perpendicular rather than parallel to the length. Pressing parallel to the length would have produced a low-density zone near the center of the specimens.

All specimens were finish ground to the final dimensions. For the harder specimens, such as $\mathrm{B}_{4} \mathrm{C}, \mathrm{B}_{4} \mathrm{C}+\mathrm{TiB}_{2}$, and $\mathrm{SiC}+\mathrm{B}_{4} \mathrm{C}$, the machining operation was slow and tedious, even with diamond tools.

\subsection{Elastic Moduli}

\section{a. Method}

The equipment and technique for determining the elastic moduli by the sonic method were the same as those reported by Spinner [3], and previously described by Hornibrook [4]. The method consists of inducing the mechanical resonant frequency of the specimen, usually by means of a tweeter-type speaker, driven by an audio oscillator. 'The resultant oscillations are detected by means of a crystal pickup which, together with the signal from the audio oscillator, produces a Lissajou pattern on a cathode ray oscilloscope.

One of the basic characteristics of the dynamic method is that the elastic moduli are determined at very low-stress levels. Thus, the possibility of the occurrence of creep, elastic hysteresis, plastic flow, or similar effects is reduced to a minimum [5].

Whenever possible, the fundamental resonant frequency of four types of vibration was determined for each specimen. These were the longitudinal, $F_{l}$; flexural vibrating flatwise, $F_{f w}$; flexural vibrating edgewise, $F_{s e}$; and torsional $F_{\imath}$. The first three types of vibration were used to determine Young's modulus, whereas the torsional mode yielded the shear modulus. The reason for determining two elastic moduli is that all the elastic constants for isotropic materials are interrelated by well-known equations in such a way that, if any two are known, the others may be calculated. In this investigation, Poisson's ratio, $\mu$, and the bulk modulus, $K$, were calculated after Young's and the shear moduli had been obtained.

For some specimens, usually the shorter ones, the longitudinal resonant frequency was too high to be detected with the equipment used. In these cases, only the flexural and torsional resonance frequencies were determined.

In three instances, Code $44\left(\mathrm{~B}_{4} \mathrm{C}\right)$, Code 43 $\left(\mathrm{B}_{4} \mathrm{C}+\mathrm{TiB}_{2}\right)$, and Code $37\left(\mathrm{SiC}+\mathrm{B}_{4} \mathrm{C}\right)$ the combination of size and density were such that the resonant frequency of the test specimens could not be detected either in the longitudinal or in the torsional modes. One specimen of each of these materials was reshaped so that the resonant torsional frequency could be obtained. The remainder of the specimens in the group were not reshaped because (1) the grinding and polishing operations were difficult and time consuming due to the extreme hardness of the $\mathrm{B}_{4} \mathrm{C}$ constituent, and (2) the reshaping operation made the specimens unsuitable for other testing.

The shear moduli and values of Poisson's ratio were calculated for each of these reshaped specimens. These values of Poisson's ratio were then assumed to be representative of the entire group of specimens of that mixture and were used to calculate the shear and bulk moduli for the remainder of the specimens. Because only one specimen was measured in shear, the data for these groups were not treated statistically.

It may be noted that it is usually possible to obtain adequate responses even when frequencies are considerably higher than what is usually regarded as the upper limit of the audiofrequency range $(20 \mathrm{kc})$. This is because the frequency response of a driver or pickup is usually higher than its rated value. The upper frequency limit for a good crystal pickup is ordinarily given as around 10 to $11 \mathrm{kc}$. Although this is the frequency above which the response falls off from being flat, it does not drop immediately to zero. There continues to be a reduced response at much higher frequencies. With the apparatus used, frequencies well above $20 \mathrm{kc}$ could usually be detected. The actual upper limit of frequency response was between 25 to $30 \mathrm{kc}$. 


\section{b. Calculations}

All of the following equations for calculating the elastic constants from the various resonant frequencies are based on the assumption that the specimens are isotropic and homogeneous. Although the individual crystals comprising the specimens are elastically anisotropic, their distribution and orientation within the specimen are random so that the assumption of isotropy would appear to be valid. However, as will be seen later, certain differences in Young's modulus, when calculated from flexural and longitudinal frequencies, indicate that either or both of these conditions (isotropy and homogeneity) were not completely satisfied in all cases.

The following well-known equations were used to calculate the speed of sound, $V_{c}$, and Young's modulus, $E_{l}$, from the longitudinal resonant frequency, $F_{l}$

$$
V_{c}=2 l F_{l},
$$

where $l=$ length in $\mathrm{cm}, F_{l}$ is in cps, and $V_{c}$ is in $\mathrm{cm} / \mathrm{sec}$, and

$$
E_{l}=V_{c}^{2} \rho,
$$

where $\rho=$ density in $\mathrm{g} / \mathrm{cm}^{3}$. If $V_{c}$ is in $\mathrm{cm} / \mathrm{sec}$, then $E_{l}$ will be in dynes $/ \mathrm{cm}^{2}$. All elastic moduli are given in kilobars where

$$
10^{9} \text { dynes } / \mathrm{cm}^{2}=1 \text { kilobar. }{ }^{4} \text {. }
$$

Correction for cross-sectional effect was neglected as too small to be significant. The following equation from Giebe and Scheibe [6] gives the amount by which the fundamental longitudinal frequency, $F_{l}$, of a prism of given rectangular cross section is less than that of an infinitely thin rod of the same length

$$
F_{l} \approx \frac{F_{m}}{1+\frac{\pi^{2} \mu^{2}\left(w^{2}-e^{2}\right)}{24 l^{2}}},
$$

where $F_{m}=$ longitudinal resonant frequency of an infinitely thin rod,

$$
\begin{aligned}
& \mu=\text { Poisson's ratio, } \\
& w=\text { width, } \\
& e=\text { edge or thickness, } \\
& l=\text { length of the specimen. }
\end{aligned}
$$

- The cgs system is used throughout as being a more desirahle form in which to develop the equations and present the fnal data. However, for the convenience of those who are more familiar with the English system of units, the final data, in appendix 11, are presented in the English as well as the metric

Kystohars may be converted to psi by means of the following equation,
Kilohing

$$
\text { Kilobars } \times 14,503.8=\text { psi. }
$$

(This conversion factor assumes a value for the acceleration of gravity, $g=$ $980.1 \mathrm{~cm} / \mathrm{sec}^{2}$.)
Substituting the dimensions for the long (6 in.) specimen and, assuming a $\mu$ value of $1 / 4$

$$
F_{m}=1.0002 F_{l}
$$

or, the resonant longitudinal frequencies of bars of the dimensions used here are 2 parts in 10,000 less than for an infinitely thin rod of the same length. This is a higher order of precision than the resonant frequency determination itself (1 part in $3,000)$, and therefore may be neglected. Since the entire lateral correction is neglible and, since Poisson's ratio is only one of the factors entering into the correction, the value of $E_{l}$ is, within the precision used here, independent of Poisson's ratio.

To calculate Young's modulus from the flexural frequencies and the shear modulus from the torsional frequency, the relations developed by Pickett [7] were used. These equations have been modified to conform to the $\mathrm{cgs}$ system.

The following pair of equations relate Young's modulus to the flatwise and edgewise flexural frequencies,

$$
\begin{aligned}
& E_{f w}=9.464 \times 10^{-10}\left(\frac{l}{e}\right)^{3} \frac{T_{1}}{w} m F_{f w}{ }^{2} \\
& E_{f e}=9.464 \times 10^{-10}\left(\frac{l}{w}\right)^{3} \frac{T_{1}}{e} m F_{f e}{ }^{2}
\end{aligned}
$$

$E_{f w}=$ Young's modulus as determined from flatwise flexural vibration, $F_{f w} ; E_{f e}=$ Young's modulus as determined from edgewise flexural vibration, $F_{f e}$; and $m=$ mass of specimen in grams. 'The numerical constant in eqs (5) and (6) is chosen so that Young's modulus will be in kilobars. The factor, $T_{1}$, depends upon $r / l$, the ratio of the radius of gyration of the cross-sectional area in the direction of vibration $(=0.288675 \times e$ or 0.288 $675 \times w$, depending on whether the vibration is flatwise or edgewise) to the length of the specimen. Pickett gives algebraic relations, graphs based on these relations, and also a table of selected numerical values from which $T_{1}$ can be determined as a function of Poisson's ratio for values of $0,1 / 6$, and $1 / 3$. Subsequently, the following equation has been offered [8] from which $T_{1}$ can be evaluated for Poisson's ratio values other than those given by Pickett,

$$
T_{1}=T\left[\frac{1+\left(0.26 \mu+3.22 \mu^{2}\right) r / l}{1+0.1328 \times r / l}\right]
$$

where $\mu$ is the particular value of Poisson's ratio and $T$ is Pickett's value of $T_{1}$ for $\mu=1 / 6$ for the corresponding value of $r / l$.

The nature of the function relating $T_{1}$ to $r / l$ is such that not only does $T_{1}$ increase as $r / l$ increases, but also the values of $T_{1}$ diverge from each other more rapidly for different values of Poisson's ratio. Therefore, the accuracy of $\mu$ becomes more critical in the accurate determination of $E_{f w}$ and $E_{\text {fe, }}$ as $r / l$ increases. 
The shear modulus, $G$, was calculated from the torsional resonant frequency $F_{t}$, by means of the following equation,

$$
G=B m F_{i}^{2}
$$

where $B$ is defined by the following relation

$$
B=\frac{4 l R}{a}
$$

where $a$ is the cross-sectional area and $R$ is the ratio of the polar moment of inertia of this crosssectional area to the "shape factor" [9] for the same cross section. The following approximation for rectangular cross section is given by Pickett [7] and based on Roark's Monograph [9],

$$
R=\frac{e / w+w / e}{4(e / w)-2.52(e / w)^{2}+0.21(e / w)^{6}} .
$$

A reexamination of the accuracy of the equation for $R$ for the dynamic shear modulus calculations has been presented [10]. The revised relation for the specimen sizes used in this study, all with width-to-thickness ratios of about 2 , is not significantly different from those calculated from the relation given.

Once Young's modulus and the shear modulus were determined, Poisson's ratio was calculated from the following equation,

$$
\mu=\frac{E}{2 G}-1 \text {. }
$$

For the 3 -in. specimens, where $E_{l}$ could not be determined, $E_{f i v}$ or $E_{f e}$ (eq (5) or (6)) was used in eq (11). However, the importance of an accurate value of $\mu$ for the determination of $E_{f w}$ or $E_{f e}$ has already been mentioned. The procedure that was followed, then, was to assume a reasonable value of $\mu$ in calculating $E_{f o}$ or $E_{f e}$ from eq (5) or (6); then by successive approximation increasingly accurate values of $E_{f w}$ or $E_{f e}$ and $\mu$ were obtained. The process ceased when two successive calculations of $E_{f w}$ or $E_{f e}$ did not vary by more than about 2 in the fourth significant figure. Usually, no more than two recalculations were necessary.

The subscript in the symbol for Poisson's ratio $\left(\mu_{l}, \mu_{f w}\right.$, or $\left.\mu_{f e}\right)$ indicates whether the longitudinally or flexurally determined values of Young's modulus were used in eq (11).

For those specimens where $F_{l}$ could not be determined, the speed of sound was calculated from the equation

$$
V_{c}=\sqrt{\frac{E_{f w}}{\rho}}
$$

The bulk modulus, $K$, is obtained from the following equation

$$
K=\frac{E}{3(1-2 \mu)} .
$$

As with Poisson's ratio, the symbols $K_{l}$ or $K_{f w}$ indicated whether $E_{l}$ and $\mu_{l}$ or $E_{f w}$ and $\mu_{f w}$ were used in the equation for the bulk modulus.

\subsection{Density}

\section{a. Bulk Density}

The bulk density was determined from the mass and volume which was calculated from the dimensions.

In order to determine the mass accurately, the specimens were cleaned with soap and water, then with trichloroethylene, and dried to constant weight either by heating at $800^{\circ} \mathrm{C}$ in an electrically heated muffle furnace or, if there was any doubt about the oxidation resistance of the materials at $800^{\circ} \mathrm{C}$, they were vacuum-dried at an absolute pressure of about $1 \times 10^{-5} \mathrm{~mm}$ of $\mathrm{Hg}$. A few of the specimens were vacuum-dried in a desiccator at about 30 microns pressure.

After cleaning and drying, all of the specimens were stored in desiccators until they could be weighed on an analytical balance. The mass was corrected for the air buoyancy referred to a barometric pressure of $760 \mathrm{~mm}$ of $\mathrm{Hg}$ and $20^{\circ} \mathrm{C}$ by the equation

Corr. mass $=[$ mass in air $\times 0.99986]$

$$
+[\text { volume } \times 0.0012] \text {. }
$$

\section{b. Theoretical Density}

The theoretical density, $\mathrm{P}$, was determined from $\mathrm{X}$-ray diffraction examination, using the following relation

$$
\mathrm{P}=\frac{N M}{V A}
$$

where $N$ is the number of molecules per unit cell, $M$ is the molecular weight, $V$ is the volume of the unit cell in angstrom units, and $A$ is Avogadro's number $\left(6.024 \times 10^{23}\right)$ used in conjunction with the newly adopted angstrom length unit.

The molecular weights of solid solutions were calculated assuming that electrostatically neutral structures exist. No theoretical density computations were made in those instances where the type of solid solution was not known, where a number of solid solutions and compounds could exist, and where the reactions between these phases were not known, and when the structures of the material were of various low orders of symmetry and the angular values of the intersecting axes were not readily available. When it could reasonably be assumed that no reactions occurred between the two or more phases present in some of the test specimens, the theoretical densities were calculated as though the specimen were composed of a "mechanical" mixture of the component phases and that the densities of each were additive according to the amounts present. 


\subsection{Precision}

The precision of the resonant frequency measurements has been given as about 1 part in $3,000(2.3 \mathrm{~b})$. The speed of sound, when calculated from the longitudinal frequency, is the most precise of all the constants given since it depends only on the length, known to about 1 part in 6,000 , and the longitudinal frequency. The error in this determination is less than 0.1 percent. When combined with the other factors involved in its determination the precision of $E_{l}$ is estimated to be better than 0.4 percent. The precision of $G, E_{f w}, E_{f e}$, and $V_{c}$ from eq (12) are estimated to be about 0.4 percent. The precision of the Poisson's ratio and bulk modulus values are, from the nature of their determination, reduced by a factor of 10 , from 0.4 percent to 4 percent.

The precision of the bulk density measurements is estimated to be about 0.2 percent.

\subsection{Statistical Treatment}

A detailed description of the statistical techniques employed and their application to the particular problems of this investigation is presented in appendix I. The basic features of this statistical approach were as follows:

In most cases two or more groups, usually consisting of 10 specimens each, of a single type of material, were supplied by the manufacturer. The different groups were either fabricated at different times, using the same batch, or fabricated using batches prepared at different times. The first condition was designed to test the uniformity of fabrication, whereas the latter condition tested the uniformity of batch preparation. As mentioned in the introduction, the elastic constants and densities were used independently as indicators of the uniformity of production.

The specimens of a single group were designated "acceptable" if the coefficient of variation was 1 percent or less. This rather arbitrary criterion of acceptability seemed reasonable on the basis of earlier testing $[11,12]$ and the data reported here. This standard of acceptability could favor some materials at the expense of others, and it should not be interpreted as a rigid criterion of the quality of any material or manufacturer's product.

The $F$-test was used to determine whether or not two or more groups of specimens were significantly different in the degree of scatter. The $t^{-}$ test was used to determine whether or not the averages of two groups of data were alike. For both these tests, the 95 percent confidence level was used. The $t$-test was applied only if the $F$-test showed the two groups to have the same degree of scatter within the specified 95 percent confidence level. The following table illustrates how these two tests were employed to evaluate the parameters of fabrication and batch preparation for the two or more groups of specimens of each material.

\begin{tabular}{|c|c|c|}
\hline $\begin{array}{c}\text { Statistical } \\
\text { test }\end{array}$ & $\begin{array}{l}\text { Entire batch mixed } \\
\text { at one time; speci- } \\
\text { mens fabricated at } \\
\text { different times. }\end{array}$ & $\begin{array}{l}\text { Batches mixed at dif- } \\
\text { ferent times; speci- } \\
\text { mens fabricated all } \\
\text { at one time. }\end{array}$ \\
\hline$F$ & $\begin{array}{l}\text { Yo significant differ- } \\
\text { ence means that } \\
\text { the separate fabri- } \\
\text { cation procedures } \\
\text { result in products } \\
\text { of comparable var- } \\
\text { iability. }\end{array}$ & $\begin{array}{l}\text { No significant differ- } \\
\text { ence means that } \\
\text { both groups of batch } \\
\text { materials were of } \\
\text { comparable varia- } \\
\text { bility as were the } \\
\text { mixing procedures. }\end{array}$ \\
\hline$t$ & $\begin{array}{l}\text { No significant dif- } \\
\text { ference means that } \\
\text { not only were the } \\
\text { fabrication proce- } \\
\text { dures of compar- } \\
\text { able variability } \\
\text { but they were suf- } \\
\text { ficiently uniform } \\
\text { to permit produc- } \\
\text { tion of products } \\
\text { with the same } \\
\text { properties. }\end{array}$ & $\begin{array}{l}\text { No significant dif- } \\
\text { ference means that } \\
\text { not only were the } \\
\text { batches of compar- } \\
\text { able variability but } \\
\text { that they were suf- } \\
\text { ficiently uniform to } \\
\text { permit fabrication } \\
\text { of products with the } \\
\text { same properties. }\end{array}$ \\
\hline
\end{tabular}

\section{Results and Discussion}

\subsection{Presentation of Data}

All tabular data are presented in appendix II. For illustration only, complete data and calculations are given for one material, Code $4, \mathrm{Al}_{2} \mathrm{O}_{3}$, in tables 2,3 , and 4 .

Table 5 gives results of the X-ray diffraction examinations. This table includes descriptions of the phases present, the unit cell parameters, and the theoretical densities calculated from the diffraction data.

Table 6 presents a summary of the elastic properties and densities for all the materials studied.
Tables 7 to 25 inclusive give the following data for each type of material separately: (a) the average value for each physical property; (b) the 95 percent confidence limits are given by the numbers following the average values; (c) the coefficient of variation $\left(=\frac{\text { standard deviation }}{\text { average }} \times 100\right)$; (d) the calculated and critical $F$-test number; and, (e) the calculated and critical $t$-test number when applicable.

The discussions of the 20 materials, generally, are given in the following order: (1) Description of each type of material, fabrication, heat treatment, and general comments on their appearance; 
(2) acceptability with respect to the coefficients of variation of the bulk densities and elastic constants; (3) comments on the significance of the statistical comparison calculations; and, (4) other discussion of data, when appropriate.

\subsection{Results for Different Materials}

\section{a. Aluminum Oxide $-\mathrm{Al}_{2} \mathrm{O}_{3}$ (Tables 7 and $7 \mathrm{a}$ )}

Code 1: The six groups of hot-pressed fused $\mathrm{Al}_{2} \mathrm{O}_{3}$ were made from the same batch and heattreated under the same conditions but at different times. These specimens were gray in color suggesting that they contained some carbon or graphite. However, one specimen of group I was heated for 30 minutes at $1,200^{\circ} \mathrm{C}$ in an oxidizing atmosphere with no appreciable loss in weight $(0.01 \%)$ and no color change.

Based upon their measured bulk densities, all of the groups would be considered "acceptable." With the exceptions of the specimens of groups IV and V, the specimens would be "acceptable" according to the variations of the elastic constants. As a single group, however, these specimens would not be "acceptable" when based upon the coefficients of variation of either thcir bulk densities or the values of the elastic constants.

Code 27: This group of seven specimens is one of a series fabricated to produce a high density, polycrystalline material, by cold-pressing and sintering. Although a relatively high density was achieved with very small variability in the bulk density measurements, the specimens would not be "acccptable", on the basis of their elastic constants variations.

Code 26: 'Two additional groups of specimens were fabricated using the best method developed for the Code 27 specimcns. Both of these groups would be "acceptable" according to their variations in bulk densities and group II would be "acceptable" with respect to the elastic constants variations. Comparisons of the propertics of both groups show that the batches and the fabrication procedures that were established were satisfactory to provide specimens having reproducible physical properties.

Code 4: 'Two groups of 10 specimens each were prepared from a very high-purity $\mathrm{Al}_{2} \mathrm{O}_{3}$. The specimens were semitranslucent and appeared to be impervious. Each group was cold-pressed and sintered at the same temperature but at different times. Both groups would be "acceptable" on the basis of the coefficients of variation of the determined properties. Statistical comparisons of the properties of both groups indicate that this material and the particular fabrication process can be used to produce uniformly reproducible specimens.

Code 3: This group of five specimens had a composition and fabrication similar to those of Code 4.
The group would be "acceptablc" on the basis of the variation of any physical property. No statistical comparison calculations were made for this and either of the groups of the Code 4 material because examination of the values of the physical properties shows that there is little, if any, difference.

Code 2: 'Two groups of 10 specimens per group were fabricated from the same material, but group I was heat-treated in a production kiln and group II was heat-treated in a laboratory kiln. Those heated in the production kiln attained a slightly higher temperature. Both groups would be "acceptable" on the basis of their bulk density variations; only the group I specimens could be considered almost "acceptable" with regard to their elastic constants variation. More important, when the various property values of both groups, with the exception of the values for Poisson's ratio, are compared statistically, the two groups are significantly different. In this instance, then, one could not predict the characteristics of a production product if that prediction is based upon the characteristics of a laboratory product.

Code 14: Twelve specimens of a high-purity $\mathrm{Al}_{2} \mathrm{O}_{3}$ were cold-pressed and sintered to produce a product that was said to be impervious to gases at elevated tcmperatures, however, the densities and elastic moduli given in table 7 were relatively low. These specimens would be "acceptable" on the basis of the coefficients of variation of any of the physical properties.

Code 15: Thesc eight specimens were fabricated in the same manner as that used for the Code 26 and 27 specimens, but using a different supplier's materials. Neither high density nor high values for the elastic constants were obtained, and the specimens would be "acceptable" only on the basis of the bulk density variations.

Code 5: Eleven specimens of a very highpurity $\mathrm{Al}_{2} \mathrm{O}_{3}$ werc cold-pressed and sintered in a "high-temperature" production kiln. A lowdensity product resulted that would be "acceptable" only on the basis of the small variation of the bulk density values

General Comments: Figure 1, based on the data in table 7 , shows the relationship betwecn the average bukk density, the average values of specd of sound, Young's modulus, and the shear modulus for the $\mathrm{Al}_{2} \mathrm{O}_{3}$ specimens. These results are in general agreement with those of Coble and Kingery [13] who found the clastic moduli of $\mathrm{Al}_{2} \mathrm{O}_{3}$. specimens to increase with decreasing porosity. When one considers that the data represent the products of three different fabricators and some five different batches, the regularity of the results is quite surprising. Whon the curves are extrapolated to the value of the theoretical X-ray density, the values of the elastic constants compare very favorably with those determined for the hot-pressed specimens that attained almost theoretical density. 


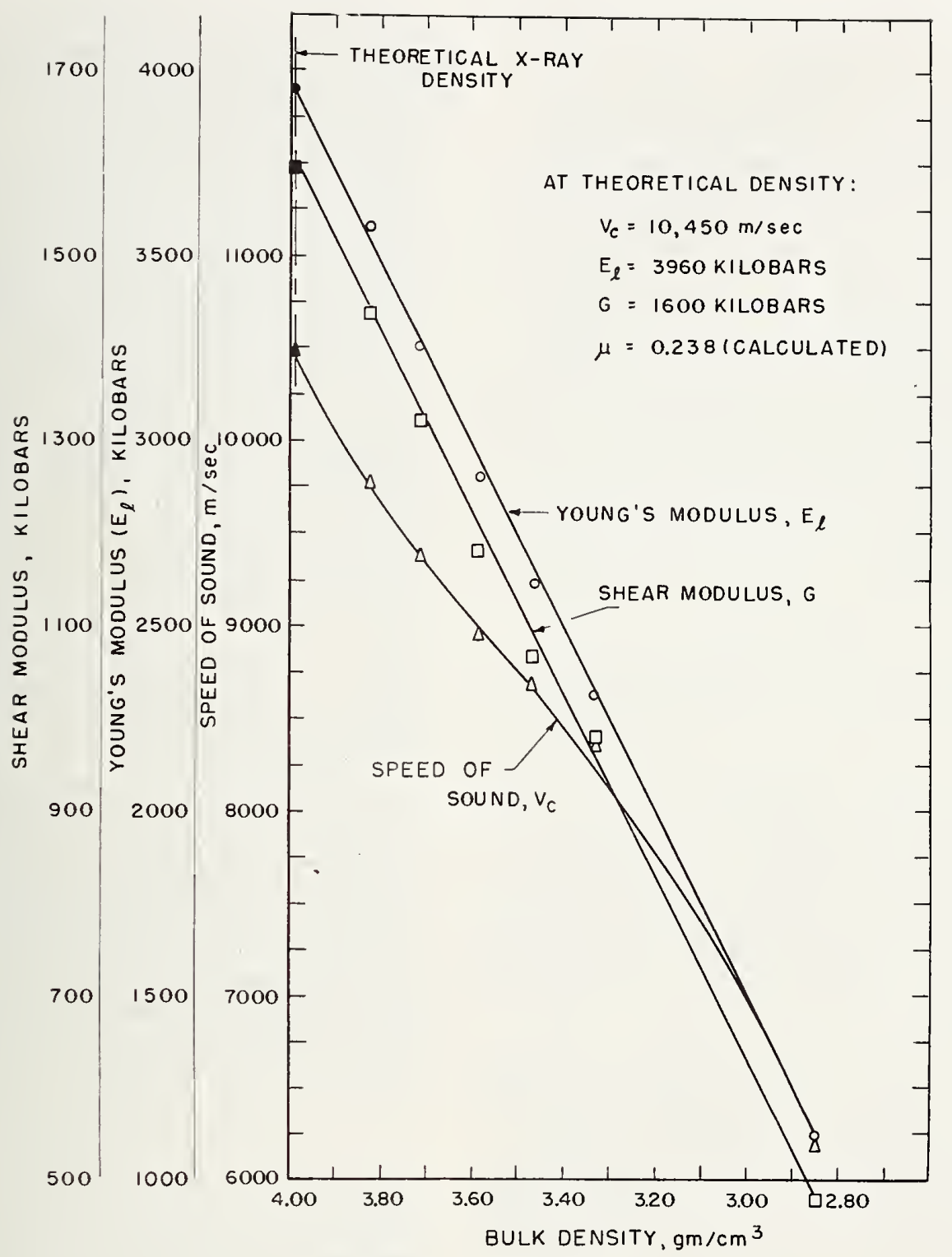

Figure 1. Data for $\mathrm{Al}_{2} \mathrm{O}_{3}$.

\section{b. Ruby Alumina- $\mathrm{Al}_{2} \mathrm{O}_{3}+\mathrm{Cr}_{2} \mathrm{O}_{3}$ (Table 8)}

Two groups of five specimens each were obtained on loan. One group contained 1/2 weight percent $\mathrm{Cr}_{2} \mathrm{O}_{3}$ (Code 6) and the other (Code 7) contained $11 / 2$ weight percent $\mathrm{Cr}_{2} \mathrm{O}_{3}$ simulating one of the compositions of natural ruby. The alumina used in compounding these specimens is the same as that used for the Code 5 specimens (sec. a). As received, the specimens were extremely porous as the result of the very low-temperature treatment that they had received. Because of small size and density, none of the resonant longitudinal vibration frequencies could be obtained. After the data given in table 8 were obtained, the specimens were heat-treated at $1,800^{\circ} \mathrm{C}$, reshaped and again tested.
The results, which are given in table 8 as codes $6 \mathrm{~B}$ and $7 \mathrm{~B}$ showed that, when these specimens were heated at a sufficiently high temperature, they would be considered "acceptable" only on the basis of the variation of the bulk density values. Although a considerable decrease was noted in the coefficients of variation of the elastic constants for the group containing the $\frac{1}{2}$ weight percent $\mathrm{Cr}_{2} \mathrm{O}_{3}$ "impurity" when they were reheated, no appreciable changes occurred in the coefficients of variation for the group containing $1 \frac{1}{2}$ weight percent $\mathrm{Cr}_{2} \mathrm{O}_{3}$. It was more interesting, however, that additional heat treatment caused only small changes in the calculated values of Poisson's ratio. The change in value for the Code 6 specimens is the reverse of the bulk density-Poisson's ratio 
trend shown for practically all of the other data available for other materials.

\section{c. Magnesium Oxide-Mgo (Tables 9 and 9a)}

Code 24: Two groups of specimens were fabricated from the same batch but heat-treated at different times to produce high-purity, highdensity test specimens by cold-pressing and sintering. Both groups would be "acceptable" because of the small variation of the bulk density values, but onty group II would be "acceptable", on the basis of variations in the elastic constants. Statistical comparison of the property values (t-test) of the two groups indicates that this material and fabrication procedure may be considered satisfactory for producing, from time to time, specimens of about the same characteristics.

Code 25: These two groups of specimens were fabricated similarly to the Code 24 specimens. Some slight differences occurred during the preparation.

Either group would be "acceptable" on the basis of the variation of their bulk densities. Statistical analyses of both groups showed that, although no really significant difference in the variability of the material was introduced because of the slight procedural change, as indicated by the $F$-test results, the change did affect the average values significantly, as indicated by the $t$-test results.

Code 23: These two groups were the first trials at producing a high-purity, high-density product. Each was made from a different source of magnesium carbonate. Each would be considered "acceptable" only on the basis of their bulk density variations.

Code 9: Two groups of 10 specimens each were fabricated from a fused $\mathrm{MgO}$ material by coldpressing and sintering. This material has a purity of +95 percent. The test specimens were extremely porous, somewhat friable, and tan in color, speckled with light-brown areas. Both groups were prepared from the same material and both were heat-treated simultaneously, but in different parts of the same kiln.

The only basis for "acceptability" of both groups would be the low coefficients of variation of the bulk density values. Comparison of data obtained for each of the physical properties of both groups shows that this material, treatment, and location in the particular kiln were such that with two exceptions ( $\mu_{f w}$ and $K_{l}$ ), there was no really significant difference according to the $F$-and $t$-tests.

\section{d. Mullite-3 $3 \mathrm{Al}_{2} \mathrm{O}_{3} \cdot 2 \mathrm{SiO}_{2}$ (Tables 10 and 10a)}

Code 16: Five groups of hot-pressed mullite, totaling 20 specimens, were made from the same material but heat-treated at different times, presumably under the same pressure-temperature conditions. Although the purities of the starting materials were about the same in Codes 16, 17, and 18 , those of Code 16 were contaminated with graphite from the arc-fusion process and the graplite mold of the hot-pressing apparatus. In addition, X-ray diffraction examination of one specimen showed that it contained mullite and at least 10 percent of free $\mathrm{Al}_{2} \mathrm{O}_{3}$.

With the exception of group IV, all would be "acceptable" on the basis of their bulk density variations; however, the entire lot as a group would be "unacceptable" on the same basis. Only group II, containing but 2 specimens, would be "acceptable", according to the coefficients of variation of the elastic properties. There appears to be some difference among most of the groups listed. Because all specimens were made from the same material, it would seem that variations in the control and operation of the hot-pressing facility were sufficient to cause significant changes in the product in three of the five groups processed.

Codes 17. and 18: Two groups of ten cold-pressed and sintered specimens each were obtained separately. The Code 17 specimens were subjected to a "short burn", while the Code 18 specimens sustained a "long burn", both at the same temperature. X-ray diffraction examination of one specimen of each group indicated that both were single-phase materials.

Both groups would be considered "acceptable" on the basis of their bulk density variations and the Code 18 specimens would be "acceptable" with respect to the elastic constants variation. Comparison of the physical properties of both groups by the $t$-test shows that the heat treatment significantly affected the characteristics of the test specimens. It is cvident that the longer heating period, although it did not materially affect the bulk density, or elastic modulus values, did result in a more uniform product.

\section{e. Mullite $+\mathrm{ZrO}_{2}$ (Table 11)}

Code 22: Onc group of 10 cold-pressed and sintered specimens were obtained that were compounded from a mixture of mullite (the same as that used for the Code 17 and 18 mullite specimens) and zircon. These were fabricated and heat-treated in a manner similar to that used for the Code 17 and 18 mullite specimens. X-ray diffraction examination of one of the test specimens showed no zircon present and also that the specimen contained mullite and about 20 percent of monoclinic $\mathrm{ZrO}_{2}$. No hypothesis is advanced for the loss of silica from the zircon, but the $\mathrm{SiO}_{2}$ formed from the decomposition is assumed to have entered the mullite phase [14].

This group could be considered "acceptable" both on the basis of the coefficients of variation for bulk density and elastic constants. If it can be assumed that these specimens and those of Code 17 received the same fabrication and heat treatments, then it appears that the addition of zircon is almost as beneficial as a "long burn" in producing more uniform property characteristics, but that the densities and elastic moduli are reduced. 


\section{f. Spinel-MgO $\cdot \mathrm{Al}_{2} \mathrm{O}_{3}$ (Tables 12 and 12a)}

Code 20: Five groups of hot-pressed spinel, totaling 20 specimens, were fabricated from the same batch composition but heat-treated at different times. The specimens appeared to be coarsely crystalline, grains of $1 / 8 \mathrm{in}$. diam being visible. The specimens were freely speckled with black areas. These areas are believed to be contaminations from both the arc-fusion process and the hot-pressing operation. X-ray diffraction examination of one specimen showed that it contained magnesia spinel and less than 5 percent of free $\mathrm{MgO}$.

All of the groups, individually or as a lot, were "acceptable" according to their bulk density variations, but "unacceptable" from the standpoint of variation of the elastic constants. When the properties of each of the groups are compared with those of all of the spccimens, a surprising consistency is noted. In fact, this spinel is one of the few hot-pressed materials that gave a fairly consistent product.

Code 21: Two groups of 8 and 10 specimens each wcre made from the same material as was used for the Code 20 specimens, except that they were fabricated by cold-pressing and sintering. Each group was heat-treated at different times. The test specimens were snow-white in color, very porous, somewhat friable, and rather weak. Two of group I were broken in handling. Unlike those of Code 20, the specimens were fine-grained.

The group II specimens could be considered "acceptable" on the basis of the buik densities but not on the basis of the elastic properties. The group I specimens were not "acceptable" on any basis. When the two groups were compared with each other by the $F$ - and $t$-test, it can be seen that the differences that occurred from processing at different times causerl a significant difference in all properties, except $\mu_{l}$.

\section{g. Thorium Dioxide- $-\mathrm{ThO}_{2}$ (Tables 13 and 13a)}

Both types of thoria described in this report, Codes 10 and 51, contain $\frac{1}{2}$ weight percent of $\mathrm{CaO}$ (usually added as $\mathrm{CaCO}_{3}$ ) for densification.

The thoria used in the preparation of Code 10 specimens was electrically-fused, while that used for the Code 51 specimens was a very pure $(99.9+\%)$, low-temperature calcined material.

Code 10: 'Two groups of 10 specimens each were cold-pressed from the same mixture and simultaneously sintered at the same furnace temperature, but in different parts of the furnace. The specimens were a light-brown with a pink cast.

Statistically, both groups would be considered "acceptable", although some of the calculated elastic constants had variations that exceeded the acceptability limits. The $F$-test showed significant differences for bulk density and bulk modulus; the only property that showed a significant difference by the $t$-test was the shear modulus. This uniformity indicates that the position in the furnace did not seriously aflect the characteristics of the products.

Code 51: This group of 10 specimens were fabricated from a mixture of very pure, low-temperature calcined $\mathrm{ThO}_{2}$ and $\mathrm{CaCO}_{3}$ by cold-pressing and sintering. 'The specimens were off-white in color. 'The statistical treatment showed that the group would be "acceptable" on the basis of both the bulk densities and the elastic constants.

\section{h. Uranium Dioxide-UO}

Code 19: The five specimens of this group, which were prepared by cold-pressing followed by sintering in a hydrogen atmosphere, had a bukk density about 95 percent of theoretical. The uranium oxicle used in fabricating the specimens had 2.05 moles rather than 2.00 moles of oxygen. This ratio changed during fabrication to 2.02 .

The group would be "acceptable" on the basis of both the bulk density and on all clastic constants, except $K_{l}$ and $K_{f i o}$.

Code 19a: One test specimen was fabricated by cold-pressing and sintering an "ammonia-precipitated" $\mathrm{UO}_{2}$ material. The measured values are included in table 14 .

\section{i. Stabilized Zirconia- $\mathrm{ZrO}_{2}+\mathrm{CaO}$ (Tables 15 and 15a)}

All of the materials described in this section contain about 5 weight percent of $\mathrm{CaO}$. When such mixtures are heated they form cubic solid solutions which are free from the discontinuous volume changes associated with the monoclinictetragonal inversions that occur between $800^{\circ} \mathrm{C}$ and $1,200^{\circ} \mathrm{C}$ in pure $\mathrm{ZrO}_{2}[15,16]$.

Code 11: Four groups of hot-pressed stabilized zirconia, totaling 18 spccimens, were made from the same mixture but heat-treated at different times.

All groups would be "acceptable" on the basis of their coefficients of variation for the bulk density, but none would be "acceptable" according to the variations of the elastic constants. A comparison between groups seems unjustified because of the extremely large variations (about 30\%) of all of the specimens, considered as a group.

Anticipating data to be presented later in this section, inspection of the data in table 15 shows that, although these hot-pressed specimens attained a very high bulk density, the values of the elastic constants were as low as (and in some instances lower than) the values determined for the cold-pressed and sintered specimens. It is believed that this anomaly is due to internal laminations and cracks in the specimens. Such faults in these test specimens could sometimes be shown to exist, although their full extent could not be readily evaluated, by judicious "probing" during the resonant frequency determinations. At times, the direction and magnitude of the flaw can be approximated, but it does not appear feasible to attempt a quantitative evaluation of the effects. Therefore, all of these, and the later, data given for stabilized 
zirconia are suspect. Although there was a small spread in the bulk density measurements, apparently indicating production uniformity, the very large spread of the elastic constants indicated that actually this was not the case. This is an excellent example of the value of the dynamic measurements in determining the variability of specimens.

Code 13: Two groups of 10 specimens, which were fabricated by cold-pressing and sintering, were made from the same material and heattreated simultaneously at the same furnace temperature, but the groups were located in different parts of the furnace.

Either group would be "acceptable" only with respect to the low coefficients of variation for the bulk densities; they would not be "acceptable" with respect to the elastic constants. With the exception of the bulk density values, statistical comparison of the elastic constants of both groups showed that the location in the furnace (assuming all else equivalent) significantly affected the characteristics of the products.

Code 12: 'These two groups of 10 specimens each were submitted by the fabricator with the comment that "considerable fabrication difficulty was experienced with longitudinal seams and transverse cracks." Both groups were made by coldpressing and sintering. They were prepared from the same mixture and heat-treated at the same temperature, but at different times, in a laboratory furnace.

These two groups showed the lowest bulk densities of any of the stabilized zirconias. On the other hand, the elastic constants are not only the highest but also the most uniform. For example, the group II specimens would be considered "acceptable" on the basis of most of the physical properties. Statistical comparison of the elastic properties of the two groups indicates that the fabricator supplied this material with uniform characteristics in spite of his fabrication difficulties.

\section{j. Alumina + Chromium- $\mathrm{Al}_{2} \mathrm{O}_{3}+\mathrm{Cr}$ (Tables 16 and 16a)}

Code 29: The group numbers of the 19 specimens of this cermet were considered as one group. Another two groups of the same material are described in the next section. With the exception of the low variation of the bulk density values, the Code 29 specimens as a single group would not be considered "acceptable".

Code 30: 'These two groups of 10 specimens each were cold-pressed and sintered. They have the same composition as the Code 29 specimens. The two groups were made from the same mixture but heat-treated at different times.

Both groups could be considered "acceptable" on the basis of bulk density or the elastic constants, with the possible classification of group I as a borderline case when considering the elastic properties. Again, because of the borderline nature of one of the groups, it is difficult to say, statistically, that the mixture can or cannot be fabricated with uniform characteristics from time to time.

Code 28: Two groups of cold-pressed and sintered $\mathrm{Al}_{2} \mathrm{O}_{3}+\mathrm{Cr}$ cermet, 10 specimens per group, were prepared from the same mixture but heattreated at different times. The composition is similar to, but not identical with, the Code 30 specimens. As was the case for all of the $\mathrm{Al}_{2} \mathrm{O}_{3}+$ $\mathrm{Cr}$ mixtures, the $\mathrm{X}$-ray diffraction examinations showed only a single chromium-metal phase. A possible explanation for the absence of $\mathrm{Al}_{2} \mathrm{O}_{3}$ reflections is that the chromium-metalbecame "smeared" over the surface during polishing, thus masking the alumina phase.

Only the group I specimens could be considered "acceptable" on the basis of their low coefficients of variation for the bulk densities and elastic constants. When the physical properties of each group are compared statistically, it is apparent that variations in heat-treatment caused a significant change in all of the properties with the possible exception of the values for Poisson's ratio.

\section{k. Ni-bonded Titanium Carbide-TiC+Ni (Tables 17 and 17a)}

Four $\mathrm{TiC}+\mathrm{Ni}$ mixtures containing 10 to 30 weight percent of $\mathrm{Ni}$ were fabricated by coldpressing and sintering. The $\mathrm{TiC}$ had about 6 weight percent of tantalum and niobium carbides in solid solution. Each of the four codes was prepared and heat-treated separately under identical conditions. The nickel content of these mixtures are:

Code 31 -about 10 wt $\% \mathrm{Ni}$

Code 32 -about 20 wt $\% \mathrm{Ni}$

Code 33 -about 30 wt $\% \mathrm{Ni}$

Code 34 -about 30 wt \% Ni (a modified Code 33 composition)

Code 31: Both groups of specimens would be considered "acceptable" on the basis of the coefficients of variation for both the bulk densities and elastic constants, although group I might be borderline. Comparison of the physical properties by the $t$-test of the two groups shows that the mixing and general fabrication controls are such that materials having about the same variability can be produced at different times; also, the $t$-test shows that this cermet can be reproduced with substantially the same physical properties.

Code 32: Both groups of specimens would be "acceptable" except for Poisson's ratio and bulk modulus. Comparison of the physical properties of the two groups shows that, although the mixing and general fabrication controls were such that a material with the same scatter in values can be reproduced from time to time, the materials were not consistent in their physical properties.

Codes 33 and 34: The same statistical comments that were given for the Code 32 material are applicable to these materials. 
General Comments: Figure 2 shows the extent of the variation of the values of the elastic constants and the bulk density with the nominal nickel content. The average values of the two groups of each mixture for codes 31,32 , and 33 were averaged to provide the data for these curves.

\section{Boron Carbide- $\mathrm{B}_{4} \mathrm{C}$ (Table 18)}

Two groups of 10 hot-pressed specimens (Code 44) were made from the same batch but each was prepared and heat-treated at a different time. For the reasons stated in section 2.3 (a), torsional frequencies were determined for only one specimen of a group; and consequently, no statistical comparisons were made.

\section{m. Boron Carbide+Titanium Diboride $-\mathrm{B}_{4} \mathrm{G}+\mathrm{TiB}_{2}$ (Table 19)}

Code 43: These four groups of five specimens were hot-pressed from the same mixture of 82 parts (volume) of $\mathrm{B}_{4} \mathrm{C}$ and 18 parts of $\mathrm{TiB}_{2}$, but each group was heat-treated at a different time.
The same comments that were given for specimen size, reshaping, and calculation method for boron carbide (sec. 2.3(a)) are applicable to these specimens. The addition of titanium diboride increased the bulk density but did not significantly affect the values of the elastic constants.

\section{n. Silicon Carbide-SiG (Tables 20 and 20a)}

Code 45: "High-purity" materials, probably less than 3 percent of uncombined silicon or carbon excess, were used for both Codes 45 and 35 . Two groups of cold-pressed and sintered specimens, 9 and 8 specimens, respectively, were prepared from the same material but heat-treated at different times. The resonant longitudinal vibration frequencies could not be determined with the available equipment on the 15-cm long specimens because of the high values of the speed of sound. Therefore, the elastic moduli were calculated only from the flexural mode of vibration.

Both groups would be "acceptable" on the basis of their variation in bulk density values, and group

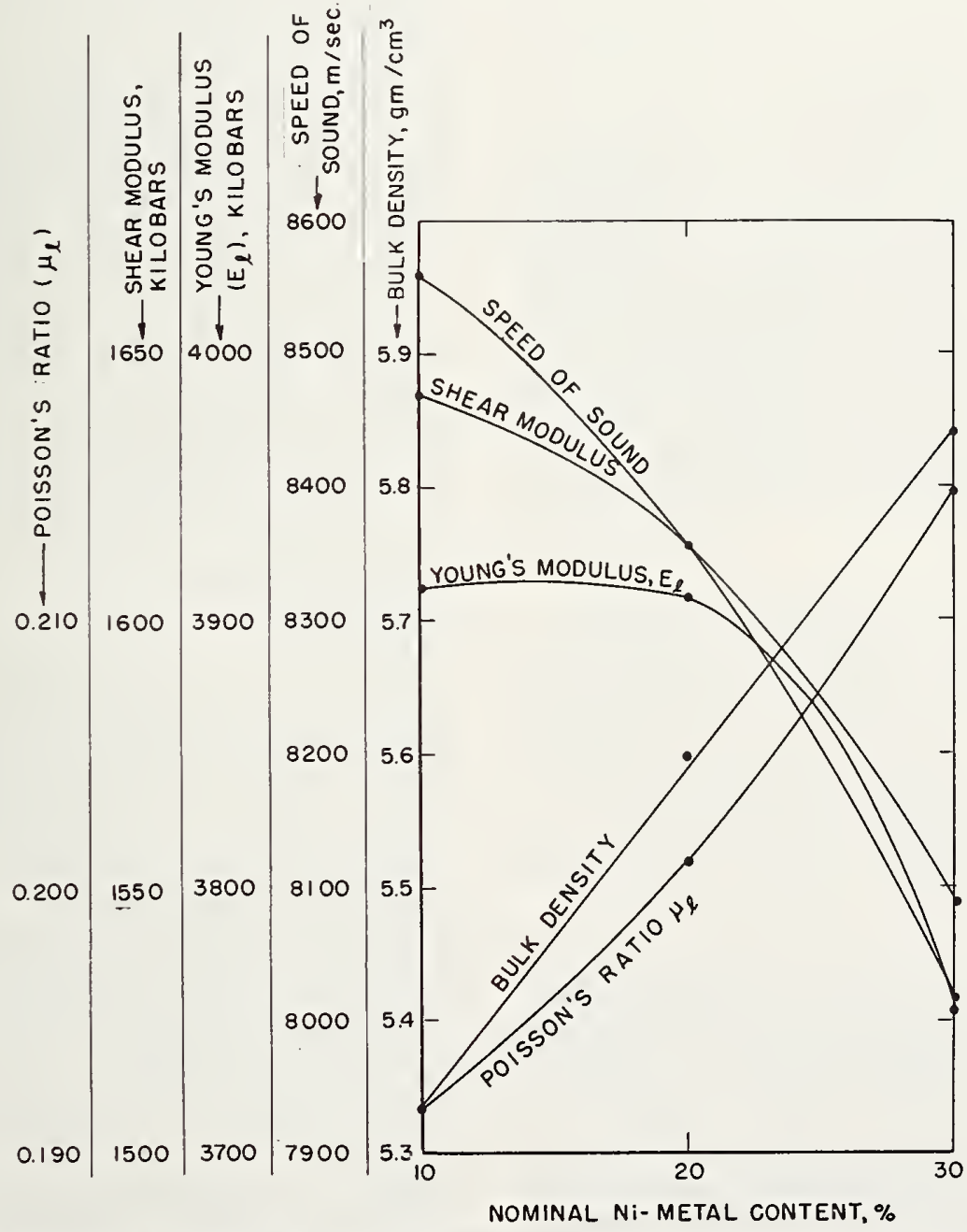

FICURE 2. Compositional dependence of the elastic constants and bulk density for TiC+Ni (codes 31 through 34). 
II would be "acceptable" with respect to the variability in elastic constants. When the physical properties of the two groups are considered, it is apparent that the two groups, except for $E_{f e}$, are significantly different.

Code 35: Two cold-pressed and sintered groups, were prepared from the same material but heattreated at different times. X-ray diffraction examination on one specimen revealed that it was composed of a mixture of cubic crystals with several hexagonal $\mathrm{SiC}$ phases. It has been shown [17] that there are some 15 or more hexagonal polytypes of $\mathrm{SiC}$, all or any of which may coexist with or without the cubic form.

On the basis of the coefficients of variation for their bulk densities only, both groups could be considered "acceptable". When the other property values of the two groups are compared by by the $F$-and $t$-test, it appears that the materials and fabrication methods can, in general, provide reproducible products, but with rather poor uniformity of physical property characteristics; the uniformity of bulk density appears to be the exception.

\section{o. Silicon Carbide + Boron Carbide $-\mathrm{SiC}+\mathrm{B}_{4} \mathrm{C}$} (Table 21)

Code 37: Each of the 4 groups of 5 specimens of this material (designated as "boron carbide bonded silicon carbide") were made from the same mixture but hot-pressed at different times. The $\mathrm{SiC}$ was the same as that used for the Code 35 specimens; the $\mathrm{B}_{4} \mathrm{C}$ was of "commercial" grade. The same comments given for specimen size, reshaping, and method of calculation for boron carbide (sec. 2.3(a)) apply here. However, it will be noted that the addition of the 10 parts of $B_{4} \mathrm{C}$ very substantially increased the bulk density and elastic moduli values.

\section{p. Zirconium Carbide-ZrC (Tables 22 and 22a)}

Code 38: Six groups of hot-pressed zirconium carbide, totaling 20 specimens, were made from the same material but pressed and heat-treated at different times. The material was of commer. cial grade. X-ray diffraction examination of one specimen showed it to be essentially a single phase material ( $\mathrm{ZrC}$ ) but that it contained a very small amount of free graphite.

Groups III, IV, V, and VI would be "acceptable" on the basis of the low variation for the bulk density values; however, the entire lot would not be "acceptable" according to the coefficients of variation of the elastic constants. Assuming all else equal, the results in table 22 show that considerable variations in heat-treatment must have occurred during the fabrication of these test specimens. As was the case with many other materials, there was very little change in Poisson's ratio with heat-treatment. q. Zirconium Diboride- $\mathrm{ZrB}_{2}$ (Tables 23 and 23a)

Code 41: Four groups of five hot-pressed specimens were made from the same material but heattreated at different times.

With the exception of the specimens of group III, all other groups would be considered "acceptable" because of their low coefficients of variation for both the bulk density and elastic constants values. When the values of each of the groups are compared with the values for the entire code, it is apparent that the values for the physical properties were not reproduced from time to time.

Code 42: Two groups of 10 hot-pressed specimens, whose composition is a modification of Code 41 , were fabricated at different times.

Comparison of the values of both groups shows that nonuniform specimens can be fabricated with reproducible properties, although neither of the groups would be "acceptable" under the criteria established.

r. Molybdenum Disilicide-MoSi ${ }_{2}$ (Tables 24 and 24a)

Code 39: Six groups of hot-pressed specimens, 19 in all, were prepared from the same material designated as of "high purity" but heat-treated at different times.

All of the groups, with the exceptions of II and III, would be "acceptable" on the basis of the low variation of their bulk densities, although the entire code would not be "acceptable"; groups IV and VI would be "acceptable" according to the coefficients of variation for the elastic constants.

\section{s. Nickel Aluminide-NiAl (Tables 25 and 25a)}

Code 40: Two groups of cold-pressed specimens were fabricated from the same mixture but heattreated at different times. The mixture was a proprietary modification of the basic composition.

Only the specimens of group I would be "acceptable" and then only on the basis of the bulk densities. When all of the physical properties of the two groups are compared, it should be noted that the indicated similarity has little meaning because of the large variability of the physical properties.

\subsection{Discussion}

One of the interesting observations was that Young's moduli obtained from the longitudinal mode of vibration were 1 to 2 percent less in most cases than those obtained from the flexural modes.

Similar measurements made with glasses [3] and other homogeneous isotropic materials [18] have shown good agreement for Young's moduli calculated from the flexural frequencies with Young's moduli calculated from the longitudinal frequencies using the same equations for both calculations as in this investigation. The observed lack of agreement for many of the materials studied here may be attributed to one or more of the following causes arising from some part of the fabrication process: (1) Variations in density in the specimen; (2) The presence of cracks within the specimen. If these cracks are not randomly distributed, their 
gross effect will be that of a structural inhomogeneity; (3) The segregation of grain sizes during fabrication [19]; and, (4) The lack of complete randomness in the orientation of the crystalline particles composing the specimen.

If the particles forming the structure assume some preferred orientation, then macroscopically the specimen will not be completely isotropic. Roth [20] has definitely found evidence of such crystalline orientation in small pressed pellets of ceramic materials from X-ray diffraction examination. The presence of some orientation is shown by a different intensity of certain lines than would be the case for a completely random orientation. Although no such clear-cut evidence was found for the specimens studied here, the possibility is not ruled out that such small preferred orientations were present.

From the few isolated instances where information was arailable for laboratory and production specimens, less variation occurred when the same material was fabricated as a production item than when it was fabricated as a laboratory item. A possible explanation is that, in each of these instances, a higher heat-treatment temperature was used for the production product. There were also some data arailable for materials heattreated in the same furnace at the same temperature but for different time intervals. In these, appreciably smaller variations in density and elastic constants occurred for those specimens heat-treated for a longer period of time. It would seem, therefore, that, although production economies would dictate a minimum time at minimum heat-treating temperatures, a more uniform and reproducible product would result from increasing both firing time and temperature. This improvement in the product appears to be readily achievable at a slightly increased production cost. The value of a statistical analysis for selecting the optimum temperature and time should be apparent.

It is anticipated that significant advances will be achiered in the uniformity of commercially available materials only recently dereloped, such as hot-pressed stabilized zirconia. As more general experience in the hot-pressing techniques is accumulated, one can reasonably expect to realize the advantages of both higher density and of optimum uniformity of the products.

The dynamic elastic constants, as measured here, appear to be more sensitive indicators of product uniformity in quality control than are bulk density measurements. However, in the case of cold-pressed and sintered specimens in which the bulk densities are within a few percent of the theoretical value, for example, thorium and uranium dioxide, Codes 10 and 19 , bulk density appears to be as sensitive a criterion as the dynamic elastic constants.

The reported information for the various types of "stabilized" zirconia (sec. 3.2.9) gives one of the very few examples available of the relative values of bulk density and dynamic elastic constants as production-control measurements for materials that are difficult to fabricate. 'The bulk density values of each of the four groups of hot-pressed specimens (Code 11) show little variation. The coefficient of variation of the bulk density of the entire code of 18 specimens is only $1 / 2$ percent, yet the Young's modulus values for the same specimens vary from 1,100 to 2,050 kilobars, and the coefficient of variation is on the order of 30 percent. Although the calculations are not shown in table 15 , the two groups of Code 13 , when considered as a whole, show a coefficient of variation of less than $1 / 2$ percent in bulk densities. On the other hand, the average $E_{f w}$ value for the 20 specimens as a whole was 1,380 kilobars with a coefficient of variation of only 8.3 percent. In the set of specimens in which difficulties were encountered from laminations and fissures (Code 12), the coefficients of variation of both the bulk density and elastic modulus values are low, although the average value of Young's modulus was 1,483 kilobars compared to 1,380 for the average of Code 13 . Although it might appear facetious, it seems possible that the Code 12 specimens were fabricated with uniform imperfections.

Inasmuch as the precision of the elastic modulus measurements was estimated to be about 0.4 percent whereas that of the density measurements was estimated as about 0.2 percent, it is pertinent to inquire to what extent the coefficients of variation of these two properties were affected by the precision of the measurements themselves. Or, stating the problem in another way, it is necessary to ascertain whether the greater variability found for the elastic modulus measurements represents a real variation from specimen to specimen, thus supporting the claim of greater sensitivity for this method as an indicator of specimen uniformity, or whether this increased variability was not merely a reflection of the lower precision of the dynamic measurements.

The equation relating the contribution to the total variability, expressed here as $\sigma_{T}$, in a property measurement, from that due to the variability in the measurement itself, $\sigma_{m}$ and that due to the variation from specimen to specimen, $\sigma_{s}$, is as follows,

$$
\sigma_{T}=\sqrt{\sigma_{m}^{2}+\sigma_{s}^{2}}
$$

or, in terms of the coefficient of variation, $V$,

$$
V_{T}=\sqrt{V_{m}^{2}+V_{s}^{2}}
$$

In this investigation, $V_{T}=1$ percent was chosen as the criterion of acceptability, $V_{m}=0.2$ percent for density measurements, and $V_{m}=0.4$ peicent for elastic modulus measurements. ${ }^{5}$

\footnotetext{
s Actually, $V_{m}$ for elastic and density measurements was better than the values given. In a normal distributicn, the coefficient of variation includes about 34 percent of the cases, whereas the estimated measures of precision about 34 percent of the cases, whereas the estimated measures of precision would probably include more than 80 percent of the cases. The results, then, make the contribution of the precision of the measurements to $T$ even smaller
than shown in the text.
} 
Therefore, for the elastic determinations

$$
1=\sqrt{(0.4)^{2}+V_{3}^{2}}
$$

and $\quad V_{s}=0.92$ percent

for density measurements,

$$
1=\sqrt{(0.2)^{2}+V_{s}^{2}}
$$

and

$$
V_{s}=0.98 \text { percent. }
$$

Thus, it is seen that for a coefficient of variation of 1 percent, the difference in precision of the elastic modulus and density measurements is a negligible factor since in both instances, by far the greater contribution to the coefficient of variation, $V_{T}$, stems from a real difference from specimen to specimen. Furthermore, as the coefficient of variation increases, the contribution from the precision of the measurement grows increasingly smaller. Conversely, the contribution from the precision of the measurements grows larger for coefficients of variation less than 1 percent. However, this is of no practical importance since all coefficients of variation of 1 percent or less were considered "acceptable" without regard to degree. However, for those elastic constants which were more indirectly computed, such as $\mu$ and $K$, and hence of decreased precision, the 1 percent coefficient of variation as a criterion becomes much less significant as, in these cases, the contribution of the precision of the measurement becomes more important and may overshadow any real specimen variability.

The problem may also be approached in another way, as follows: If a 1 percent coefficient of variation is set as a criterion of acceptability for density measurements and the precision of this measurement is 0.2 percent and the contribution of $V_{s}$ is found to be 0.98 percent then what would be an equivalent coefficient of variation to set for elastic modulus measurements? These have a precision of 0.4 percent and $V_{s}$ is also 0.98 percent. The coefficient of variation under these conditions is obtained from

$$
V_{T}=\sqrt{(0.4)^{2}+(0.98)^{2}}=1.05 \% .
$$

This value is seen not to be significantly different from the coefficient of variation actually set and groups of specimens having such a coefficient of variation would indeed be classed as borderline cases of acceptability.

In addition to its use as an indicator for determining the uniformity of production for particular groups of specimens, it is interesting to estimate the variability of the elastic moduli of all the materials of this investigation, taken as a whole; and to compare this variability with that of a different material, steel, which is generally considered to be much more uniform with respect to this same property.

Taking $E_{l}$ whenever available, and $E_{f w}$ otherwise, the following summary was prepared for all the materials studied;

$$
\begin{gathered}
\text { Range in coefficient } \\
\text { of variation } \\
0 \text { to } 1 \% \\
0 \text { to } 2 \% \\
0 \text { to } 2.5 \% \\
0 \text { to } 3.0 \%
\end{gathered}
$$$$
\text { Percentage of }
$$$$
\text { specimens }
$$$$
44
$$$$
\begin{aligned}
& 62 \\
& 72
\end{aligned}
$$$$
81
$$

Analagous data for steel is not readily found. However, one study [21] gives the following results for specimens of "black sheet steel": V, for speci.. mens cut in direction of rolling $=2.4$ percent. Average of $\mathrm{E}=1,962$ kilobars; $V$, for specimens cut transverse to direction of rolling $=2.6$ percent, average of $\cdot E=2,053$ kilobars; $V$, for specimens taken as a single group, 3.3 percent, average value of $\mathrm{E}=2,006$ kilobars. Thus, it is seen that, if either value of $V$ for steel is taken for comparison, about 70 percent of all the specimens of this investigation would be included, and, if the coefficient of variation of all the steel specimens without regard to direction of rolling had been taken for comparison (which seems more reasonable), then more than 80 percent of all the materials of this investigation would be included. These data [21] were for only one type of steel and may not be representative. But, if they are at all indicative, then the materials of this investigation, as a whole, compare favorably with a material which has traditionally been regarded as quite uniform.

It is believed that the present study shows that a relatively simple statistical approach can be valuable not only to the designers and engineers, but also to the fabricators and suppliers. One of the main deterrents to the use of ceramic and cermet materials in many applications where they seem to be potentially useful is the lack of knowledge of the physical properties and constants of these materials, and, when such information is available, the lack of confidence in the uniformity or reliability of the reported values. A great deal of information on product uniformity could be provided by the fabricators and suppliers, usually without additional expense, by statistically analyzing the data that are already available to the manufacturer.

The author thanks Jack Shartsis for performing most of the computations, Nancy 'Tighe for performing some of the later experiments and calculations, and Robert S. Roth for performing the $\mathrm{X}$ ray analysis. 


\section{Appendix I. Statistical Treatment of Data}

The following description is not intended as a basic exposition of the statistical concepts involved but rather as an aid to those who might desire to perform the same (or similar) calculations and wish to have some understanding of the significance of the results. All of the computations used in this report are discussed and described in detail by Youden [22] and Dixon and Massey [23].

Let " $x$ " 1epresent a value of any property in one group of specimens, " $y$ " represent a value for the same property of another group, " $\bar{x}$ " represent the average value of any property of the first group, " $\bar{y}$ " represent the average value of the same property of the second group, " $n$ " represent the number of values determined for any property in the first group, and " $m$ " represent the number of values determined for the same property of the second group; then statistical calculations (based upon the assumption that the sets of data of all of the determined properties of the materials follow follow the normal distribution law) are performed according to formulas (A), (B), (C), and (D) which apply to the first group. Similar formulas with $x$ replaced by $y$ apply to the second group. Parts (E) and (F) apply to both groups.

(A) Standard deviation of an individual determination $=S=\sqrt{\text { variance }}$

or

$$
=\sqrt{\frac{\sum x_{i}^{2}-\frac{\left(\sum x_{i}\right)^{2}}{n}}{n-1}} .
$$

$$
=\sqrt{\frac{\left(x_{1}^{2}+x_{2}^{2}+\ldots+x_{n}^{2}\right)-\left(x_{1}+x_{2}+\ldots+x_{n}\right)^{2} / n}{n-1}}
$$

(B) Standard deviation of the average of " $n$ " individual values $=S^{\prime}=\frac{S}{\sqrt{n}}$

(C) Coefficient of variation $V$, in $\%=\frac{S}{\bar{x}}(100)$

(D) Ninety-five percent confidence limits (C. L.) for the average are given by

$$
\bar{x} \pm S^{\prime} t \text { in } \%=\frac{S}{\sqrt{n}} .
$$

Where $t$ is the upper 2.5 percent point of the $t$ distribution for $n-1$ degrees of freedom. If such limits are calculated for many sets of data, there will be approximately 95 percent of the sets for which the limits enclose the true average.

(E) The $F$-test, essentially, is a method for comparing the "precision" of two sets of data for the same property. It provides one with a criterion for determining at a selected confidence level whether a significant difference exists between the scatter of two (or more) sets of data; that is, whether the groups (or materials, etc.) used to obtain that data are of a different degree of variability. In this study, the 95 percent confidence level was used. The $F$-number that is calculated from the expression,

$$
F=\frac{S_{a}^{2}}{S_{b}^{2}}
$$

where $S_{a}^{2}$ is always the larger number of the two being examined, is compared to tabulated critical $F$-values. The tabulated critical $F$-value selected, is in this situation that for the upper 2.5 percent point of $F$. If the calculated value is higher than the critical value, a significant difference does exist.

(F) The t-test, essentially, is a method for comparing the "accuracy" of two sets of data for the same property. The $t$-test should be applied to the data of two groups only when the $F$-test has shown that these data sets are of comparable variability. The $t$-test provides one with a criterion for determining whether a significant difference exists at a selected confidence level between two averages, $\bar{x}$ and $\bar{y}$, on the basis of the spread of the individual values, $S_{x}$ and $S_{y}$, used to compute those averages. This test, however, does not allow one to determine the accuracy of either $\bar{x}$ or $\bar{y}$ unless, of course, the true value is known.

As is the case with the $F$-test, the $t$-value that is calculated is compared to tabulated critical $t$-values and, if the calculated value is higher than the critical value, a significant difference does exist (see the similar discussion of significance under subsection (E), preceding). The calculated value is obtained from the expression

$$
t=\frac{\bar{x}-\bar{y}}{S_{p}} \sqrt{\frac{n \times m}{n+m}}
$$

with $n+m-2$ degrees of freedom, where $S_{p}$ is the pooled standard deviation of the individual values of both groups, $S_{x}$ and $S_{y}$, and is obtained from

$$
S_{p}=\sqrt{\frac{\left[\sum x_{i}^{2}-\left(\sum \mathrm{x}_{i}\right)^{2} / \mathrm{n}\right]+\left[\sum y_{i}^{2}-\left(\sum y_{i}\right)^{2} / m\right]}{(n-1)+(m-1)}} .
$$

During the early part of this study, it was a part of the computation procedure to perform the $F$ and $t$-tests to compare the values of $E_{l}, E_{f w}$, and $E_{f e}$, in pairs, and those of $\mu_{l}$ and $\mu_{f w}$. Very rarely were significant differences found to exist and, therefore, the time-consuming calculations were neglected for at least the latter half of the data obtained. However, occasional check calculations were made, but the results of such comparisons within a group are not included in this compilation of data. 
The preceding relations could be applied to the data obtained in this investigation in several ways. The approach selected is given as follows. Each of the suppliers of materials for the "bank" was asked to prepare his specimens in either of two ways: (1) Compound the same starting composition at two different times but fabricate each group identically; or, (2) compound one large quantity of the starting composition and fabricate each group separately. All fabrications were to achieve the maximum practical bulk density and it was to be uniform throughout the specimens.

The calculations of the standard deviation of an individual measurement of each group and the coefficient of variation for all of the properties permits one to use the reliability of the measurements of any property as a criterion for determining the product uniformity or acceptability. That acceptability may be based upon an arbitrary or specified standard variation. If a verage values were determined repeatedly and if in each instance 95 percent confidence limits were calculated for the average value, then in the long run we would expect that 95 percent of the confidence limits would include the true average value.

Application of the $F$ - and $t$-tests to the data obtained from specimens prepared under the first condition allows one to state that there was or was not a significant difference in the compounding procedures of the same nominal composition at different times. In a similar way the $F$ - and $t$-tests can show whether or not the fabrication differences (such as heating at different times, or in different types of furnaces, or at different temperatures in the same furnace) had a significant effect on either the scatter of the values obtained or the average of the property values determined.

This series of statistical computations has another important value. Some of the suppliers of the specimens for this "bank" took the opportunity to fabricate specimens, from the same batch composition, both in the laboratory and on the production line. Here, then, was an excellent opportunity to evaluate the results of a laboratory or pilot-plant experiment and a production run. It seemed, therefore, that the statistical methods described should be of considerable interest for many types of laboratory and production-control evaluations.

When it was shown that a significant difference existed for the $F$-test, it was concluded that the materials were not of comparable variability due to a variation either during the compounding or the fabrication stages depending upon the production conditions. Under these conditions, one must logically conclude that the $t$-test is not applicable because the materials of each group were not of comparable scatter ( $F$-test results).

Briefly then, under the conditions imposed, the results of the $F$-test show whether material of comparable variability is produced, and the $t$ test shows whether it can be supplied with reproducible properties from time to time. It must be re-emphasized that one must not blindly apply such conclusions to groups of data for which other conditions may have been varied. The $F$ - and $t$-tests are not as restrictive as may be implied from this discussion.

\section{Appendix II. Tabular Information}

The locations of the tabular data for each material discussed in the previous sections of this report are presented below.

Table 7-Data for $\mathrm{Al}_{2} \mathrm{O}_{3}$

Table 8-Data for Ruby

Table 9-Data for $\mathrm{MgO}$

Table 10 -Data for Mullite- $3 \mathrm{Al}_{2} \mathrm{O}_{3} \cdot 2 \mathrm{SiO}_{2} \ldots \ldots$

Table 11-Data for Mullite $+\mathrm{ZrO}_{2} \ldots$

Table 12-Data for Spinel-MgO $\cdot \mathrm{Al}_{2} \mathrm{O}_{3}-\ldots$

Table 13-Data for $\mathrm{ThO}_{2 \ldots} \ldots$

Table 14 -Data for $\mathrm{UO}_{2}$

Table 15-Data for "Stabilized" $\mathrm{ZrO}_{2 \ldots} \ldots \ldots$

Table 16-Data for $\mathrm{Al}_{2} \mathrm{O}_{3}+\mathrm{Cr}_{\ldots} \ldots \ldots$

Table 17-Data for $\mathrm{TiC}+\mathrm{Ni}_{\ldots} \ldots \ldots \ldots$

Table 18 - Data for $\mathrm{B}_{4} \mathrm{C}$

Table 19-Data for $\mathrm{B}_{4} \mathrm{C}+\mathrm{TiB}_{2} \ldots$

Table 20-Data for SiC.

Table 21-Data for $\mathrm{SiC}+\mathrm{B}_{4} \mathrm{C}_{\ldots}$

Table 22-Data for $\mathrm{ZrC}$

Table 23-Data for $\mathrm{ZrB}_{2}$

Table 24-Data for $\mathrm{MoSi}_{2 \ldots} \ldots \ldots \ldots$

Table 25-Data for NiAl
The symbols in the tables have the following significance:

$E_{l}=$ Young's modulus from the longitudinal resonant frequency.

$E_{f_{w}}=$ Young's modulus from the flexural resonant frequency in flatwise vibration.

$E_{f e}=$ Young's modulus from the flexural resonant frequency in edgewise vibration.

$G=$ Shear Modulus.

$\mu_{l}=$ Poisson's ratio using $E_{l}$ and $G$.

$\mu_{f w}=$ Poisson's ratio using $E_{f w}$ and $G$.

$\mu_{f e}=$ Poisson's ratio using $E_{f_{e}}$ and $G$.

$\mathrm{K}_{l}=$ Bulk modulus, using $E_{l}$ and $\mu_{l}$.

$\mathrm{K}_{f w}=$ Bulk modulus, using $E_{f w}$ and $\mu_{f w}$.

Underlined $F$ and $t$ values indicate that a significant difference exists between the compared groups.

The $F$ and $t$ ratios marked with an asterisk indicate that the comparison has been made with the critical value similarly marked. Two critical values derive from the fact that in choosing this tabulated (critical) value different numbers of specimens are involved. 
TABLE 1. Materials, source, and general fabrication data

\begin{tabular}{|c|c|c|c|c|c|c|c|c|c|c|}
\hline \multirow{2}{*}{ Material } & \multirow{2}{*}{ Nominal composition } & \multirow{2}{*}{$\begin{array}{l}\text { Code } \\
\text { No. }\end{array}$} & \multirow{2}{*}{ Source } & \multirow{2}{*}{$\begin{array}{c}\text { No. of } \\
\text { specimens }\end{array}$} & \multirow{2}{*}{$\begin{array}{l}\text { No. of } \\
\text { groups }\end{array}$} & \multirow{2}{*}{$\begin{array}{c}\text { Reported } \\
\text { purity }\end{array}$} & \multicolumn{2}{|c|}{ Manufacturer's } & \multirow{2}{*}{$\begin{array}{l}\text { Fabrica } \\
\text { tion a } \\
\text { method }\end{array}$} & \multirow{2}{*}{$\begin{array}{l}\text { Temperature } \\
\text { of heating } b\end{array}$} \\
\hline & & & & & & & Designation & Control No. & & \\
\hline Alumina -. & $\mathrm{Al}_{2} \mathrm{O}_{3}$ & $\begin{array}{r}1 \\
2 \\
3 \\
4 \\
5 \\
14 \\
15 \\
26 \\
27\end{array}$ & $\begin{array}{l}\mathrm{H} \\
\mathrm{H} \\
\mathrm{H} \\
\mathrm{H} \\
\mathrm{F} \\
\mathrm{F} \\
\mathrm{G} \\
\mathrm{G} \\
\mathrm{G}\end{array}$ & $\begin{array}{r}20 \\
20 \\
5 \\
20 \\
11 \\
12 \\
8 \\
14 \\
7\end{array}$ & $\begin{array}{l}6 \\
2 \\
1 \\
2 \\
1 \\
1 \\
1 \\
2 \\
1\end{array}$ & \begin{tabular}{c}
$\%$ \\
$99+$ \\
$98+$ \\
$99+$ \\
$99+$ \\
\hdashline \\
99.9 \\
99.9 \\
99.9
\end{tabular} & $\begin{array}{l}\text { Pure } \\
\text { Vitreous } \\
\end{array}$ & \begin{tabular}{l} 
C-5633 \\
LA77365 \\
LA 603 \\
LA 603 \\
$562 \mathrm{~V}$ \\
$555 \mathrm{Q}$ \\
\\
\hdashline
\end{tabular} & $\begin{array}{l}\mathrm{HP} \\
\mathrm{CP} \\
\mathrm{CP} \\
\mathrm{CP} \\
\mathrm{CP} \\
\mathrm{CP} \\
\mathrm{CP} \\
\mathrm{CP} \\
\mathrm{CP}\end{array}$ & $\begin{array}{l}{ }^{\circ} C . \\
(2,000+) \\
1,725 \\
1,750 \\
1,750 \\
1,650 \\
1,680 \\
1,800 \\
1,800 \\
1,800\end{array}$ \\
\hline Ruby alumina & $\begin{array}{l}99.5 \% \mathrm{Al}_{2} \mathrm{O}_{3}+0.5 \mathrm{Cr}_{2} \mathrm{O}_{3} \\
98.5 \mathrm{Al}_{2} \mathrm{O}_{3}+1.5 \mathrm{Cr}_{2} \mathrm{O}_{3}\end{array}$ & $\begin{array}{l}6 \\
7\end{array}$ & $\begin{array}{l}\mathrm{F} \\
\mathrm{F}\end{array}$ & $\begin{array}{l}5 \\
5\end{array}$ & $\begin{array}{l}1 \\
1\end{array}$ & & 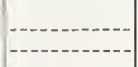 & $\begin{array}{l}\text { A33A } \\
\text { A } 34 \mathrm{~A}\end{array}$ & $\underset{\mathrm{CP}}{\mathrm{CP}}$ & $\begin{array}{l}1,800 \\
1,800\end{array}$ \\
\hline Magnesia . . & $\mathrm{MgO}$ & $\begin{array}{r}9 \\
23 \\
24 \\
25\end{array}$ & $\begin{array}{l}\mathrm{H} \\
G \\
G \\
G \\
G\end{array}$ & $\begin{array}{l}20 \\
10 \\
11 \\
14\end{array}$ & \begin{tabular}{l|}
2 \\
2 \\
2 \\
2
\end{tabular} & $\begin{array}{l}99.9 \\
99.9 \\
99.9\end{array}$ & \begin{tabular}{|c|} 
Fused \\
\\
\end{tabular} & $\mathrm{M}-202$ & $\begin{array}{l}\mathrm{CP} \\
\mathrm{CP} \\
\mathrm{CP} \\
\mathrm{CP}\end{array}$ & $\begin{array}{l}1,780 \\
1,800 \\
1,800 \\
1,800\end{array}$ \\
\hline Mullite_-_--_.. & $3 \mathrm{Al}_{2} \mathrm{O}_{3} \cdot 2 \mathrm{SiO}_{2}$ & $\begin{array}{l}16 \\
17 \\
18\end{array}$ & $\begin{array}{l}\mathrm{H} \\
\mathrm{F} \\
\mathrm{F}\end{array}$ & $\begin{array}{r}20 \\
8 \\
10\end{array}$ & $\begin{array}{l}5 \\
1 \\
1\end{array}$ & & Fused & $\mid \mathrm{C}-5657$ & $\begin{array}{l}\mathrm{HP} \\
\mathrm{CP}\end{array}$ & $\begin{array}{l}(1,750+) \\
1,650 \\
1,650\end{array}$ \\
\hline Mullite+zirconia & $3 . \mathrm{Al}_{2} \mathrm{O}_{3} \cdot 2 \mathrm{SiO}_{2}+\mathrm{ZrO}_{2}$ & 22 & $\mathrm{~F}$ & 10 & 1 & & & $397 Z$ & $\mathrm{CP}$ & 1,650 \\
\hline Spinel_............ & $\mathrm{MgO} \cdot \mathrm{Al}_{2} \mathrm{O}_{3}$ & $\begin{array}{l}20 \\
21\end{array}$ & $\stackrel{\mathrm{H}}{\mathrm{H}}$ & $\begin{array}{l}20 \\
18\end{array}$ & $\begin{array}{l}5 \\
2\end{array}$ & & Fused & $\begin{array}{l}\text { C-5633 } \\
431927\end{array}$ & $\underset{\mathrm{CP}}{\mathrm{HP}}$ & $\left(\begin{array}{l}(1,850+) \\
1,785\end{array}\right.$ \\
\hline Thoria....- & $\mathrm{ThO}_{2}+0.5 \% \mathrm{CaO}$ & $\begin{array}{l}10 \\
51\end{array}$ & $\stackrel{\mathrm{H}}{\mathrm{H}}$ & $\begin{array}{l}17 \\
10\end{array}$ & $\begin{array}{l}2 \\
1\end{array}$ & & $\ldots$ & 431924 & $\underset{\mathrm{CP}}{\mathrm{CP}}$ & $\begin{array}{l}1,785 \\
1,800\end{array}$ \\
\hline Urania_-_.....- & $\mathrm{UO}_{2}$ & $\begin{array}{l}19 \\
19 \mathrm{a}\end{array}$ & $\stackrel{\mathrm{C}}{\mathrm{G}}$ & $\begin{array}{l}5 \\
1\end{array}$ & $\begin{array}{l}1 \\
1\end{array}$ & $\begin{array}{l}99.9 \\
99.9\end{array}$ & & $\begin{array}{l}\mathrm{MCW}_{\mathrm{NH}}-\mathrm{ppt}\end{array}$ & $\underset{\mathrm{CP}}{\mathrm{CP}}$ & $\begin{array}{l}1,750 \\
1,750\end{array}$ \\
\hline Stabilized zirconia & $\mathrm{ZrO}_{2}+5 \% \mathrm{CaO}$ & $\begin{array}{l}11 \\
12 \\
13\end{array}$ & $\begin{array}{l}\mathrm{H} \\
\mathrm{H} \\
\mathrm{H}\end{array}$ & $\begin{array}{l}18 \\
20 \\
20\end{array}$ & $\begin{array}{l}4 \\
2 \\
2\end{array}$ & & 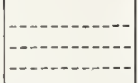 & $\begin{array}{l}\text { C-5633 } \\
\text { LZ7590 } \\
\text { LZ604 }\end{array}$ & $\begin{array}{l}\mathrm{HP} \\
\mathrm{CP}\end{array}$ & $\begin{array}{l}(2,000+) \\
1,720 \\
(1,700+)\end{array}$ \\
\hline $\begin{array}{l}\text { Chromium bonded alumina } \\
\text { Chromium bonded alumina } \\
\text { (modified). }\end{array}$ & $\begin{array}{l}\mathrm{Al}_{2} \mathrm{O}_{3}+\mathrm{Cr} \\
\mathrm{Al}_{2} \mathrm{O}_{3}+\mathrm{Cr}+\mathrm{Mo}+\mathrm{TiO}_{2}\end{array}$ & $\begin{array}{l}28 \\
29 \\
30\end{array}$ & $\begin{array}{l}\mathrm{D} \\
\mathrm{D} \\
\mathrm{D}\end{array}$ & $\begin{array}{l}20 \\
19 \\
20\end{array}$ & $\begin{array}{l}2 \\
1 \\
2\end{array}$ & & $\begin{array}{l}\text { LT-1 } \\
\text { LT-1B } \\
\text { LT-1B }\end{array}$ & $\begin{array}{l}\text { MT895/823 } \\
\text { Mixed } \\
4168 / 169\end{array}$ & $\begin{array}{l}\text { Cast } \\
\text { Cast } \\
\text { Cast }\end{array}$ & $\begin{array}{l}(1,600) \\
(1,600) \\
(1,600)\end{array}$ \\
\hline $\begin{array}{l}\text { Nickel bonded titanium } \\
\text { carbide. }\end{array}$ & $\mathrm{TiC}+\mathrm{Ni}$ & $\begin{array}{l}31 \\
32 \\
33 \\
34\end{array}$ & $\begin{array}{l}\mathrm{E} \\
\mathrm{E} \\
\mathrm{E} \\
\mathrm{E}\end{array}$ & $\begin{array}{l}20 \\
20 \\
20 \\
20\end{array}$ & $\begin{array}{l}2 \\
2 \\
2 \\
2\end{array}$ & & $\begin{array}{l}\text { K150B } \\
\text { K151B } \\
\text { K152B } \\
\text { K162B }\end{array}$ & \begin{tabular}{|l}
$3010 / 3011$ \\
$2459 / \mathrm{SC} 297$ \\
$2697 / 2739$ \\
$2752 / 2889$
\end{tabular} & $\begin{array}{l}\mathrm{CP} \\
\mathrm{CP} \\
\mathrm{CP} \\
\mathrm{CP}\end{array}$ & $\begin{array}{l}1,300 \text { to } 1,500 \\
1,300 \text { to } 1,500 \\
1,300 \text { to } 1,500 \\
1,300 \text { to } 1,500\end{array}$ \\
\hline Boron carbide_............... & $\mathrm{B}_{4} \mathrm{C}$ & 44 & $\mathrm{H}$ & 20 & 2 & & $-\cdots$ & $\mathrm{X} 431925$ & HP & $\cdots$ \\
\hline $\begin{array}{l}\text { Boron carbide - titanium } \\
\text { boride. }\end{array}$ & $\mathrm{B}_{4} \mathrm{C}+\mathrm{TiB}_{2}(82 / 18$ vol $)$ & 43 & $\mathrm{H}$ & 20 & 4 & & & B5592 & HP & \\
\hline Silicon carbide . -............ & $\mathrm{SiC}$ & $\begin{array}{l}35 \\
45\end{array}$ & $\frac{\mathrm{H}}{\mathrm{B}}$ & $\begin{array}{l}19 \\
17\end{array}$ & $\begin{array}{l}2 \\
2\end{array}$ & & $\mathrm{~K} T$ & $5347 / 5343$ & $\stackrel{\mathrm{CP}}{\mathrm{CP}}$ & $(1,800+)$ \\
\hline $\begin{array}{l}\text { Silicon carbide-boron car- } \\
\text { bide. }\end{array}$ & $\mathrm{SiC}+\mathrm{B}_{4} \mathrm{C}(90 / 10 \mathrm{wt})$ & 37 & $\mathrm{H}$ & 20 & 4 & & $\ldots$ & $\mathrm{C}-5572$ & НР & \\
\hline Zirconium carbide & $\mathrm{ZrC}$ & 38 & H & 20 & 6 & & & C-5633 & HP & - nen \\
\hline Zirconium di-boride.-..-.-. & $\mathrm{ZrB}_{2}$ & $\begin{array}{l}41 \\
42\end{array}$ & $\underset{\mathrm{A}}{\mathrm{H}}$ & $\begin{array}{l}20 \\
20\end{array}$ & $\begin{array}{l}4 \\
2\end{array}$ & -..-- & 101 & $\begin{array}{l}5572 / 5592 \\
178-10 / 20\end{array}$ & $\underset{\mathrm{CP}}{\mathrm{HP}}$ & $(2,000+)$ \\
\hline Molybdenum disilicide..... & $\mathrm{MoSi}_{2}$ & 39 & H & 19 & 6 & & & $2372 / 5592$ & HP & \\
\hline Nickel aluminide.... & $\mathrm{NiAl}$ & 40 & $A$ & 14 & 2 & & 1505 & $927 \mathrm{~A} / \mathrm{B}$ & $\mathrm{CP}$ & $(1,500+)$ \\
\hline
\end{tabular}

HP represents hot-pressed in graphite mold, CP represents cold-pressed and sintered, and Cast represents slipcast and sintered.

$b$ The heating temperatures given in parenthesis are approximate. 
TABLE 2. Room temperature dynamic elastic constants for $\mathrm{Al}_{2} \mathrm{O}_{3}-$ Code 4

\begin{tabular}{|c|c|c|c|c|c|c|c|c|c|c|}
\hline Specimen & $\rho$ & $V_{e}$ & $E_{l}$ & $E_{f w}$ & $E_{f e}$ & $G$ & $\mu l$ & $\mu_{f}$ & $K_{l}$ & $K_{f w}$ \\
\hline $\begin{array}{l}4.1 \\
4.2 \\
4.3 \\
4.4 \\
4.5 \\
4.6 \\
4.7 \\
4.8 \\
4.9 \\
4.10\end{array}$ & $\begin{array}{r}\mathrm{g} / \mathrm{cm}^{3} \\
3.829 \\
3.813 \\
3.831 \\
3.810 \\
3.819 \\
3.828 \\
3.825 \\
3.824 \\
3.831 \\
3.829\end{array}$ & $\begin{array}{r}m / s e c \\
9699 \\
9649 \\
9696 \\
9635 \\
9679 \\
9682 \\
9673 \\
9684 \\
9714 \\
9691\end{array}$ & $\begin{array}{r}\text { Kilobars } \\
\text { a3601.3 } \\
3550.2 \\
3601.7 \\
3537.3 \\
3577.3 \\
3588.3 \\
3579.3 \\
3586.5 \\
3615.2 \\
3596.5\end{array}$ & $\begin{array}{c}\text { Kilobars } \\
3584 \\
3523 \\
3578 \\
3509 \\
3555 \\
3566 \\
3550 \\
3566 \\
3599 \\
3574\end{array}$ & $\begin{array}{c}\text { Kilobars } \\
3593 \\
3537 \\
3583 \\
3546 \\
3563 \\
3571 \\
3562 \\
3573 \\
3608 \\
3584\end{array}$ & $\begin{array}{c}\text { Kilobars } \\
\mathbf{1 4 4 7} \\
\mathbf{1 4 2 5} \\
\mathbf{1 4 4 5} \\
1421 \\
1437 \\
1439 \\
1437 \\
1441 \\
1449 \\
\mathbf{1 4 4 1}\end{array}$ & $\begin{array}{l}0.244 \\
.246 \\
.246 \\
.245 \\
.245 \\
.247 \\
.245 \\
.244 \\
.248 \\
.248\end{array}$ & $\begin{array}{l}0.238 \\
.236 \\
.238 \\
.235 \\
.237 \\
.239 \\
.235 \\
.237 \\
.242 \\
.240\end{array}$ & $\begin{array}{c}\text { Kilobars } \\
2348 \\
2330 \\
2363 \\
2311 \\
2334 \\
2361 \\
2340 \\
2338 \\
2386 \\
2378\end{array}$ & $\begin{array}{c}\text { Kilobars } \\
2280 \\
2226 \\
2273 \\
2206 \\
2251 \\
2276 \\
2233 \\
2263 \\
2324 \\
2292\end{array}$ \\
\hline $\begin{array}{l}\text { Average } \\
95 \% \text { C, L } \\
\text { Std. dev } \\
\text { Coef. var.......... }\end{array}$ & $\begin{array}{l}3.824 \\
0.005 \\
0.008 \\
0.2 \%\end{array}$ & $\begin{array}{c}9680 \\
17 \\
23 \\
0.2 \%\end{array}$ & $\begin{array}{c}3583.35 \\
18.3 \\
25.54 \\
0.71 \%\end{array}$ & $\begin{array}{c}3561 \\
20 \\
28 \\
0.8 \%\end{array}$ & $\begin{array}{c}3572 \\
15 \\
21 \\
0.6 \%\end{array}$ & $\begin{array}{r}1438 \\
7 \\
9 \\
0.6 \%\end{array}$ & $\begin{array}{l}0.246 \\
0.001 \\
0.001 \\
0.5 \%\end{array}$ & $\begin{array}{l}0.238 \\
0.002 \\
0.002 \\
0.9 \%\end{array}$ & $\begin{array}{r}2349 \\
17 \\
23 \\
1.0 \%\end{array}$ & $\begin{array}{r}2263 \\
25 \\
35 \\
1.5 \%\end{array}$ \\
\hline $\begin{array}{l}4.11 \\
4.12 \\
4.13 \\
4.14 \\
4.15 \\
4.16 \\
4.17 \\
4.18 \\
4.19 \\
4.20\end{array}$ & $\begin{array}{l}3.832 \\
3.816 \\
3.815 \\
3.830 \\
3.819 \\
3.821 \\
3.817 \\
3.819 \\
3.834 \\
3.820\end{array}$ & $\begin{array}{l}9694 \\
9653 \\
9683 \\
9688 \\
9673 \\
9677 \\
9667 \\
9668 \\
9691 \\
9677\end{array}$ & $\begin{array}{r}33600.7 \\
3555.7 \\
3577.3 \\
3594.4 \\
3572.7 \\
3577.8 \\
3567.7 \\
3569.3 \\
3600.5 \\
3577.1\end{array}$ & $\begin{array}{l}3583 \\
3532 \\
3552 \\
3572 \\
3542 \\
3549 \\
3536 \\
3546 \\
3580 \\
3550\end{array}$ & $\begin{array}{l}3592 \\
3546 \\
3564 \\
3582 \\
3556 \\
3566 \\
3550 \\
3551 \\
3588 \\
3555\end{array}$ & $\begin{array}{l}1446 \\
1428 \\
1436 \\
1444 \\
1433 \\
1436 \\
1433 \\
1432 \\
1446 \\
1437\end{array}$ & $\begin{array}{l}0.245 \\
.245 \\
.241 \\
.245 \\
.247 \\
.246 \\
.245 \\
.246 \\
.245 \\
.245\end{array}$ & $\begin{array}{l}0.239 \\
.237 \\
.233 \\
.237 \\
.236 \\
.236 \\
.234 \\
.238 \\
.238 \\
.236\end{array}$ & $\begin{array}{l}2356 \\
2323 \\
2307 \\
2346 \\
2351 \\
2347 \\
2329 \\
2342 \\
2352 \\
2338\end{array}$ & $\begin{array}{l}2291 \\
2235 \\
2215 \\
2263 \\
2236 \\
2239 \\
2214 \\
2255 \\
2275 \\
2239\end{array}$ \\
\hline $\begin{array}{l}\text { Average..... } \\
95 \% \text { C.L.... } \\
\text { Std. dev..... } \\
\text { Coef. var........ }\end{array}$ & $\begin{array}{l}3.822 \\
0.005 \\
0.007 \\
0.2 \%\end{array}$ & $\begin{array}{c}9677 \\
9 \\
12 \\
0.1 \%\end{array}$ & $\begin{array}{c}3579.32 \\
10.6 \\
14.84 \\
0.41 \%\end{array}$ & $\begin{array}{r}3554 \\
13 \\
18 \\
0.5 \%\end{array}$ & $\begin{array}{r}3565 \\
12 \\
17 \\
0.5 \%\end{array}$ & $\begin{array}{c}1437 \\
4 \\
6 \\
0.4 \%\end{array}$ & $\begin{array}{l}0.245 \\
0.001 \\
0.001 \\
0.6 \%\end{array}$ & $\begin{array}{l}0.236 \\
0.001 \\
0.002 \\
0.8 \%\end{array}$ & $\begin{array}{c}2339 \\
11 \\
15 \\
0.7 \%\end{array}$ & $\begin{array}{r}2246 \\
18 \\
25 \\
1.1 \%\end{array}$ \\
\hline $\begin{array}{l}\text { F-test: } \\
\text { Critical } \\
\text { Calculated..- }\end{array}$ & $\begin{array}{l}4.03 \\
1.16\end{array}$ & $\begin{array}{l}4.03 \\
3.59\end{array}$ & $\begin{array}{l}4.03 \\
2.96\end{array}$ & $\begin{array}{l}4.03 \\
2.37\end{array}$ & $\begin{array}{l}4.03 \\
1.62\end{array}$ & $\begin{array}{l}4.03 \\
2.20\end{array}$ & $\begin{array}{l}4.03 \\
1.13\end{array}$ & $\begin{array}{l}4.03 \\
1.30\end{array}$ & $\begin{array}{l}\text { 4. } 03 \\
\text { 2. } 26\end{array}$ & $\begin{array}{l}4.03 \\
2.01\end{array}$ \\
\hline $\begin{array}{l}\text { t-test: } \\
\quad \text { Critical } \\
\quad \text { Calculated... }\end{array}$ & $\begin{array}{l}2.10 \\
0.79\end{array}$ & $\begin{array}{l}2.10 \\
0.39\end{array}$ & $\begin{array}{l}2.10 \\
0.43\end{array}$ & $\begin{array}{l}2.10 \\
0.60\end{array}$ & $\begin{array}{l}2.10 \\
0.84\end{array}$ & $\begin{array}{l}2.10 \\
0.35\end{array}$ & $\begin{array}{l}\text { 2. } 10 \\
1.30\end{array}$ & $\begin{array}{l}2.10 \\
1.64\end{array}$ & $\begin{array}{l}2.10 \\
1.13\end{array}$ & $\begin{array}{l}2.10 \\
0.42\end{array}$ \\
\hline
\end{tabular}

×These data are reported to give figures only for the purpose of illustrating the statistical computations shown in table 3.

TABLE 3. Statistical calculations for $\mathrm{Al}_{2} \mathrm{O}_{3}$

Young's modulus $E_{l}$-Code 4 a

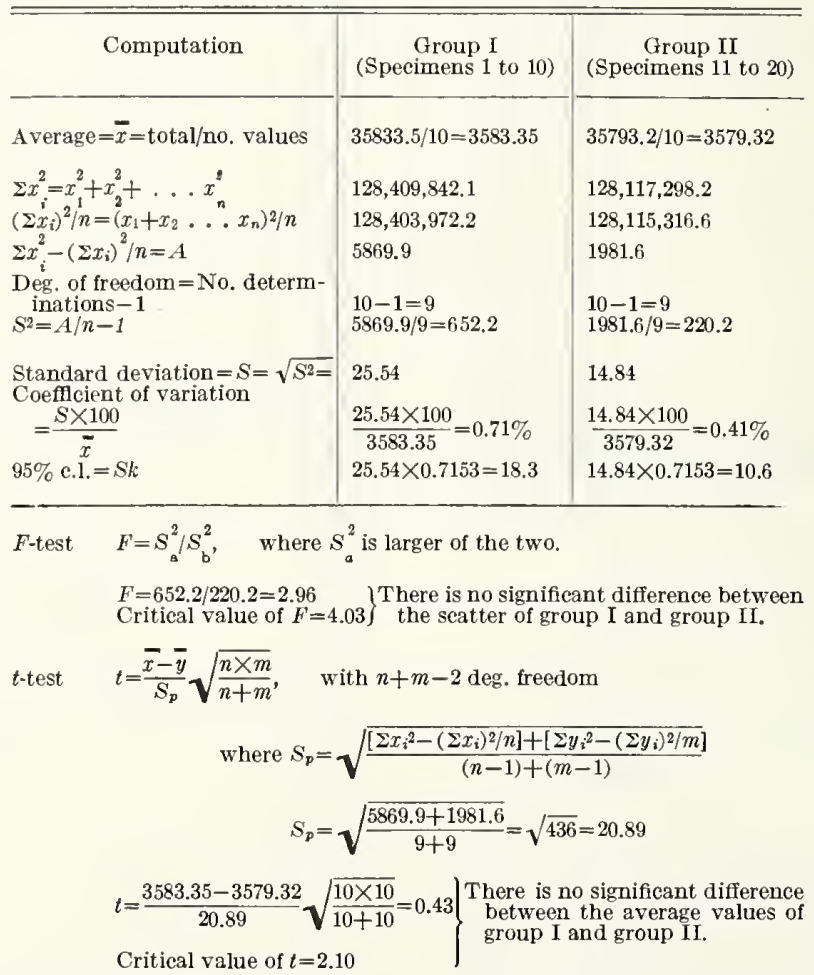

- The actual data records each value to the least one significant figure more than those given in table 2. 
TABLE 4. Bulk density and dynamic elastic constants calculations for specimen 4.1- see table 2

Length $=l=15.253 \mathrm{~cm} ;$ width $=w=1.270 \mathrm{~cm} ;$ edge $=e=0.6359 \mathrm{~cm}$.

Weight $=47.1555$ grams.

Resonant frequencies: longitudinal, $F_{l}=31,792 \mathrm{cps.}$

flexural flatwise, $F_{f_{w}}=2,700 \mathrm{cps}$.

flevural edgewise, $F_{f_{e}}=5,302 \mathrm{cps}$.

torsional, $F_{t}=14,948 \mathrm{cps}$.

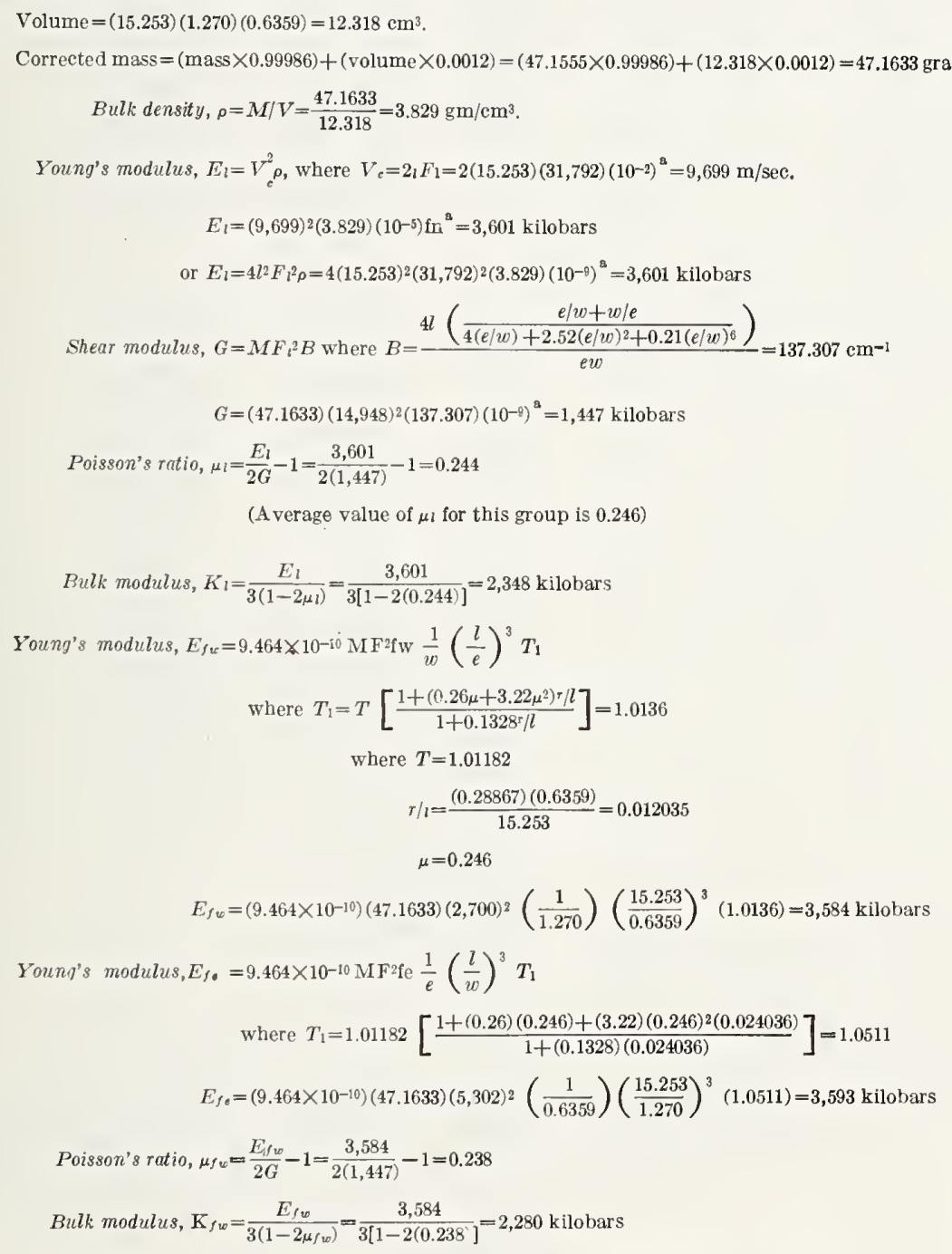

- The factors $10^{-2}, 10^{-5}$, and $10^{-9}$ are necessary for the conversion of the units given, such as $\frac{\mathrm{cm}}{\mathrm{sec}}$ to $\frac{\text { meters }}{\mathrm{sec}}$ for $V_{c}$ and $\frac{\text { dynes }}{\mathrm{cm}^{2}}$ to kilobars for elastic modull. 
TABLE 5. Summary of X-ray diffraction and bulk density data

\begin{tabular}{|c|c|c|c|c|c|c|c|c|c|}
\hline \multirow{2}{*}{ Material } & \multirow{2}{*}{ Code } & \multicolumn{3}{|c|}{ X-ray examination } & \multirow{2}{*}{$\begin{array}{l}\text { Theoret- } \\
\text { ical } \\
\text { density }\end{array}$} & \multicolumn{3}{|c|}{ Bulk density } & \multirow{2}{*}{$\begin{array}{l}\text { Densifi- } \\
\text { cation }\end{array}$} \\
\hline & & Phases present & Lattice constants & Strueture & & Group & No. spec. & Avg. & \\
\hline $\mathrm{Al}_{2} \mathrm{O}_{3}$ & $\begin{array}{l}1 \\
2\end{array}$ & $\begin{array}{l}\text { Single phase } \\
\text { Single phase }\end{array}$ & $\begin{array}{l}A \\
\mathrm{a}=4.758_{9} \\
\mathrm{c}=12.99_{3} \\
\mathrm{a}=4.759_{6} \\
\mathrm{c}=12.99_{3}\end{array}$ & $\begin{array}{l}\text { Hex. } \\
\text { Hex. }\end{array}$ & $\begin{array}{l}\mathrm{g} / \mathrm{cm}^{3} \\
3.986 \\
3.985\end{array}$ & $\begin{array}{l}\text { All } \\
\text { II }\end{array}$ & $\begin{array}{l}20 \\
10 \\
10\end{array}$ & $\begin{array}{c}\sigma / \mathrm{cm}^{3} \\
3.942 \\
3.714 \\
3.584\end{array}$ & $\begin{array}{ll}\% & \\
& 99 \\
& \\
& 93 \\
& 90\end{array}$ \\
\hline Ruby $\mathrm{Al}_{2} \mathrm{O}_{3}$ & 6 & $\begin{array}{l}\text { Single phase solid solution } \\
\text { Single phase solid solution }\end{array}$ & $\begin{array}{l}a=4.760_{1} \\
c=12.99_{3} \\
a=4.758_{3} \\
c=13.00_{3}\end{array}$ & $\begin{array}{l}\text { Hex. } \\
\text { Hex. }\end{array}$ & $\begin{array}{l}3.991 \\
4.004\end{array}$ & -- & 5 & $\begin{array}{l}3.728 \\
\text { 3. } 661\end{array}$ & $\begin{array}{l}93 \\
91\end{array}$ \\
\hline $\mathrm{MgO}$ & 24 & $\mathrm{MgO}_{-}$ & $a=4.2125$ & Cubic & 3. 600 & I & 6 & 3.502 & 97 \\
\hline $\begin{array}{l}\text { Mullite: } \\
\qquad 3 \mathrm{Al}_{2} \mathrm{O}_{3} \cdot 2 \mathrm{SiO}_{2}\end{array}$ & $\begin{array}{l}16 \\
17 \\
18\end{array}$ & $\begin{array}{l}\text { Mullite plus at least } 10 \% \mathrm{Al}_{2} \mathrm{O}_{3} \\
\text { Single phase } \\
\text { Single phase. }\end{array}$ & - & $\begin{array}{l}\text { Ortho.t } \\
\text { Hex. } \\
\text { Ortho. } \\
\text { Ortho. }\end{array}$ & 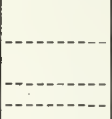 & All & $\begin{array}{r}20 \\
8 \\
10\end{array}$ & $\begin{array}{l}2.963 \\
\text { 2. } 771 \\
2.779\end{array}$ & -- \\
\hline Mullite $+\mathrm{ZrO}_{2}$ & 22 & $\begin{array}{l}\text { Mullite plus about } 20 \% \text { monoelinie } \\
\mathrm{ZrO}_{2} \text {, no zircon. }\end{array}$ & $-\ldots$ & $\begin{array}{l}\text { Ortho. }+ \\
\text { Mon. }\end{array}$ & $\cdots$ & & 10 & 2. 768 & - \\
\hline $\begin{array}{l}\text { Spinel: } \\
\quad \mathrm{MgO} \cdot \mathrm{Al}_{2} \mathrm{O}_{3}\end{array}$ & $\begin{array}{l}20 \\
21\end{array}$ & $\begin{array}{l}\text { Spinel plus small excess } \mathrm{MgO} \text {. } \\
\text { Spinel plus small excess } \mathrm{MgO}\end{array}$ & $\begin{array}{l}\mathrm{a}=8.082_{0} \\
\mathrm{a}=8.085_{0}\end{array}$ & $\begin{array}{l}\text { Cubic } \\
\text { Cuhic }\end{array}$ & $\begin{array}{l}3.580 \\
3.576\end{array}$ & $\begin{array}{l}\text { All } \\
\text { II }\end{array}$ & $\begin{array}{r}20 \\
8 \\
10\end{array}$ & $\begin{array}{l}3.510 \\
2.451 \\
2.522\end{array}$ & $\begin{array}{l}98 \\
69 \\
71\end{array}$ \\
\hline $\mathrm{ThO}_{2} \mathrm{c}$ & $\begin{array}{l}10 \\
51\end{array}$ & $\begin{array}{l}\text { Single phase solid solution } \\
\text { Single phase solid solution. }\end{array}$ & $\begin{array}{l}a=5.5968 \\
a=5.597\end{array}$ & $\begin{array}{l}\text { Cubic } \\
\text { Cubie }\end{array}$ & $\begin{array}{l}9.821 \\
9.820\end{array}$ & II & $\begin{array}{r}9 \\
8 \\
10\end{array}$ & $\begin{array}{l}9.722 \\
9.664 \\
9.702\end{array}$ & $\begin{array}{l}99 \\
98 \\
99\end{array}$ \\
\hline $\mathrm{UO}_{2}$ & 19 & $\mathrm{UO}_{2}$ & $a=5.471$ & Cubic & 10.949 & I & 5 & 10.37 & 95 \\
\hline Stab. $\mathrm{ZrO}_{2}$ & $\begin{array}{l}11 \\
12\end{array}$ & $\begin{array}{l}\text { Single phase solid solution } \\
\text { Solid solution plus small amount } \\
\text { monoclinic } \mathrm{ZrO} \mathrm{O}_{2} \text {. }\end{array}$ & $\begin{array}{l}a=5.119_{5} \\
a=5.117_{3}\end{array}$ & $\begin{array}{l}\text { Cubic } \\
\text { Cubic }\end{array}$ & $\begin{array}{l}5.754 \\
5.762\end{array}$ & $\begin{array}{l}\text { All } \\
\text { I } \\
\text { II }\end{array}$ & $\begin{array}{l}18 \\
10 \\
10\end{array}$ & $\begin{array}{l}5.634 \\
4.966 \\
4.971\end{array}$ & $\begin{array}{l}98 \\
86 \\
86\end{array}$ \\
\hline $\mathrm{Al}_{2} \mathrm{O}_{3}+\mathrm{Cr}$ & $\begin{array}{l}28 \\
29\end{array}$ & $\begin{array}{l}\text { Cr+faint peak; poor pattern because } \\
\mathrm{Cr} \text { smear. } \\
\mathrm{Cr}+\mathrm{Al}_{2} \mathrm{O}_{3} \text { (see Code } 28 \text { ) }\end{array}$ & $\begin{array}{l}\mathrm{Cr}, \mathrm{a}=2.88+ \\
\mathrm{Cr}, \mathrm{a}=2.936\end{array}$ & ------- & & II & $\begin{array}{l}10 \\
10 \\
19\end{array}$ & $\begin{array}{l}5.958 \\
5.944 \\
6.053\end{array}$ & \\
\hline $\mathrm{TiC}+\mathrm{Ni}$ & $\begin{array}{l}31 \\
32 \\
33 \\
34\end{array}$ & $\begin{array}{l}\mathrm{TiC}+(\mathrm{Ni}) \\
\mathrm{TiC}+\mathrm{Ni} \\
\mathrm{TiC}+\mathrm{Ni} \\
\mathrm{TiC}+\mathrm{Ni}\end{array}$ & $\begin{array}{l}\mathrm{TiC}, \mathrm{a}=4.325_{4} \\
\mathrm{TiC}, \mathrm{a}=4.330_{1} \\
\mathrm{TiC}, \mathrm{a}=4.332_{8} \\
\mathrm{TiC}, \mathrm{a}=4.331_{1}\end{array}$ & $\begin{array}{l}\text { Cubic } \\
\text { Cubic } \\
\text { Cubic } \\
\text { Cubic }\end{array}$ & $\begin{array}{l}\text { b } 5.430 \\
\text { b } 5.800 \\
\text { b } 6.174 \\
\text { b } 6.367\end{array}$ & $\begin{array}{l}\text { I } \\
\text { II } \\
\text { I } \\
\text { II } \\
\text { I } \\
\text { II } \\
\text { I } \\
\text { II }\end{array}$ & $\begin{array}{l}10 \\
10 \\
10 \\
10 \\
10 \\
10 \\
10 \\
10\end{array}$ & $\begin{array}{l}\text { 5. } 341 \\
\text { 5. } 343 \\
\text { 5. } 654 \\
\text { 5. } 541 \\
\text { 5. } 862 \\
\text { 5. } 821 \\
5.723 \\
5.882\end{array}$ & $\begin{array}{l}98 \\
98 \\
97 \\
96 \\
95 \\
94 \\
90 \\
92\end{array}$ \\
\hline $\mathrm{B}_{4} \mathrm{C}$ & 44 & $\mathrm{~B}_{4} \mathrm{C}+\mathrm{Cg}$ & - & Hex. & -.-.- & I & 10 & 2.506 & \\
\hline $\mathrm{B}_{4} \mathrm{C}+\mathrm{TiB}_{2}$ & 43 & $\mathrm{~B}_{4} \mathrm{C}+\mathrm{TiB}_{2}$ & $\begin{array}{l}\mathrm{B}_{4} \mathrm{C}\left\{\begin{array}{l}\mathrm{a}=\mathbf{5} .61 \\
\mathrm{c}=\mathbf{1 2 . 0 7}\end{array}\right. \\
\mathrm{TiB}_{2}\left\{\begin{array}{l}\mathrm{a}=3.028 \\
\mathrm{c}=3.228\end{array}\right.\end{array}$ & Hex. & & II & 5 & 2.815 & -- \\
\hline $\mathrm{SiC}$ & $\begin{array}{l}35 \\
45\end{array}$ & $\begin{array}{l}\text { Mixture of cubie and several hexag- } \\
\text { onal poly types. }\end{array}$ & & & & I & $\begin{array}{r}10 \\
9 \\
0\end{array}$ & $\begin{array}{l}\text { 2. } 576 \\
2.596\end{array}$ & ----1 \\
\hline & & & & & & II & 8 & 3.128 & -n-n----- \\
\hline $\mathrm{SiC}+\mathrm{B}_{4} \mathrm{C}$ & 37 & Same as Code 35 plus $\mathrm{B}_{4} \mathrm{C}_{\ldots}$ & & & & All & 20 & 3.082 & -- \\
\hline $\mathrm{ZrC}$ & 38 & ZrC plus faint Cg peak & $a=4.6865$ & Cubic & 6.661 & All & 20 & 6.118 & 92 \\
\hline $\mathrm{ZrB}_{2}$ & $\begin{array}{l}41 \\
42\end{array}$ & $\begin{array}{l}\mathrm{ZrB}_{2} \text { and few unknown peaks } \\
\mathrm{ZrB}_{2} \text { and few unknown peaks }\end{array}$ & $\begin{array}{l}a=3.166_{0} \\
c=3.536_{5}\end{array}$ & Hex. & 6.102 & $\begin{array}{l}\text { All } \\
\text { I } \\
\text { II }\end{array}$ & $\begin{array}{l}20 \\
10 \\
10\end{array}$ & $\begin{array}{l}5.585 \\
4.557 \\
4.524\end{array}$ & $-\cdots$ \\
\hline $\mathrm{MoSi}_{2}$ & 39 & $\mathrm{MoSi} \mathrm{i}_{2}$ & $\begin{array}{l}a=3.20 \\
c=7.85\end{array}$ & Tetragonal & 6.29 & I & 4 & 5.987 & 95 \\
\hline $\mathrm{NiAl}$ & 40 & NiAl and few unknown peaks.....-- & $a=4.082_{4}$ & Cubic & 8.382 & II & $\begin{array}{r}10 \\
4\end{array}$ & $\begin{array}{l}5.763 \\
5.656\end{array}$ & $\begin{array}{l}69 \\
68\end{array}$ \\
\hline
\end{tabular}

a Values based upon the calculated bulk density and the theoretical density calculated from the NBS lattice constant determination.

b Values based upon the assumption that no reaction occurs between the two phases present and, therefore, that they are "mechanical" mixtures.

c These high density materials contain $1 / 2$ wt $\% \mathrm{CaO}$. 
TABLE 6. Summary of the dynamic elastic constants and other physical constants ${ }^{\mathrm{a}}$

\begin{tabular}{|c|c|c|c|c|c|c|c|c|c|c|c|c|c|}
\hline \multirow{2}{*}{$\begin{array}{l}\mathrm{M} \text { ateria] } \\
\mathrm{Al}_{2} \mathrm{O}_{3}\end{array}$} & \multirow{2}{*}{$\begin{array}{r}\text { Code } \\
\\
1 \\
27 \\
26 \\
4 \\
3 \\
2 \\
14 \\
15 \\
5\end{array}$} & \multirow{2}{*}{$\begin{array}{c}\begin{array}{c}\text { Fabrica- } \\
\text { tion b }\end{array} \\
\\
\mathrm{HP} \\
\mathrm{CP} \\
\mathrm{CP} \\
\mathrm{CP} \\
\mathrm{CP} \\
\mathrm{CP} \\
\mathrm{CP} \\
\mathrm{CP} \\
\mathrm{CP}\end{array}$} & \multicolumn{2}{|c|}{ Bulk density } & \multicolumn{2}{|c|}{ Speed of sound } & \multicolumn{2}{|c|}{ Young's modulus } & \multicolumn{2}{|c|}{ Shear modulus } & \multirow{2}{*}{$\begin{array}{c}\begin{array}{c}\text { Poisson's } \\
\text { ratio }\end{array} \\
\\
\\
(0.254) \\
(.221) \\
(.236) \\
.246 \\
.239 \\
.232 \\
.224 \\
.187 \\
.170\end{array}$} & \multicolumn{2}{|c|}{ Bulk modulus } \\
\hline & & & $\begin{array}{l}\mathrm{g} / \mathrm{cm}^{3} \\
3.942 \\
3.904 \\
3.902 \\
3.824 \\
3.825 \\
3.714 \\
3.470 \\
3.335 \\
2.850\end{array}$ & $\begin{array}{l}l b / f t^{3} \\
246.1 \\
243.7 \\
243.6 \\
238.7 \\
238.8 \\
231.9 \\
216.6 \\
208.2 \\
177.9\end{array}$ & $\begin{array}{c}m / s e c \\
(\mathrm{~d} 10,020) \\
(9,540) \\
(9,900) \\
9,680 \\
9,675 \\
9,361 \\
8,676 \\
8,340 \\
6,236\end{array}$ & $\begin{array}{c}f t / \mathrm{sec} \\
(32,870) \\
(31,300) \\
(32,480) \\
31,760 \\
31,740 \\
30,710 \\
28,460 \\
27,360 \\
20,460\end{array}$ & \begin{tabular}{|c|} 
Kilobars \\
$(3,958)$ \\
$(3,555)$ \\
$(3,824)$ \\
3,583 \\
3,580 \\
3,255 \\
2,612 \\
2,317 \\
1,109
\end{tabular} & $\begin{array}{r}p s i \\
\left(57.41 \times 10^{6}\right) \\
(51.56) \\
(55.46) \\
51.97 \\
51.92 \\
47.21 \\
37.88 \\
33.61 \\
16.08\end{array}$ & $\begin{array}{r}\text { Kilobars } \\
1,565 \\
1,453 \\
1,548 \\
1,438 \\
1,445 \\
1,321 \\
1,067 \\
977 \\
479\end{array}$ & $\begin{array}{r}p s i \\
22.70 \times 10^{6} \\
21.07 \\
22.45 \\
20.86 \\
20.96 \\
19.16 \\
15.48 \\
14.17 \\
6.95\end{array}$ & & $\begin{array}{r}\text { Kilobars } \\
(2,645) \\
(2,129) \\
(2,415) \\
2,349 \\
2,289 \\
2,018 \\
1,579 \\
1,235 \\
533\end{array}$ & $\begin{array}{r}p s i \\
\left.\text { (38. } 36 \times 10^{6}\right) \\
(30.88) \\
(35.03) \\
34.07 \\
33.20 \\
29.27 \\
22.90 \\
17.91 \\
7.73\end{array}$ \\
\hline Ruby $\mathrm{Al}_{2} \mathrm{O}_{3}$ & $\begin{array}{l}6 \\
7\end{array}$ & $\underset{\mathrm{CP}}{\mathrm{CP}}$ & $\begin{array}{l}\text { 3. } 728 \\
\text { 3. } 661\end{array}$ & $\begin{array}{l}232.7 \\
228.6\end{array}$ & $\begin{array}{l}(9,570) \\
(9,470)\end{array}$ & $\begin{array}{l}(31,400) \\
(31,070)\end{array}$ & $\begin{array}{l}(3,412) \\
(3,284)\end{array}$ & $\begin{array}{l}(49.49) \\
(47.63)\end{array}$ & $\begin{array}{l}1,368 \\
1,285\end{array}$ & $\begin{array}{l}19.84 \\
18.64\end{array}$ & $\begin{array}{r}(0.247) \\
(.258)\end{array}$ & $\begin{array}{l}(2,251) \\
(2,234)\end{array}$ & $\begin{array}{l}(32.65) \\
(32.40)\end{array}$ \\
\hline $\mathrm{MgO}$ & $\begin{array}{r}24 \\
25 \\
23 \\
9\end{array}$ & $\begin{array}{l}C P \\
C P \\
C P \\
C P\end{array}$ & $\begin{array}{l}3.506 \\
3.483 \\
3.479 \\
2.648\end{array}$ & $\begin{array}{l}218.9 \\
217.4 \\
217.2 \\
165.3\end{array}$ & $\begin{array}{r}(9,170) \\
(9,080) \\
(9,090) \\
5,732\end{array}$ & $\begin{array}{c}(30,090) \\
(29,790) \\
(29,820) \\
18,810\end{array}$ & $\begin{array}{c}(2,947) \\
(2,873) \\
(2,872) \\
870\end{array}$ & $\begin{array}{c}(42.74) \\
(41.67) \\
(41.65) \\
12.62\end{array}$ & $\begin{array}{r}1,243 \\
1,242 \\
1,207 \\
374\end{array}$ & $\begin{array}{r}18.03 \\
18.01 \\
17.51 \\
5.42\end{array}$ & $\begin{array}{c}(0.186) \\
(.157) \\
.191) \\
.163\end{array}$ & $\begin{array}{r}(1,564) \\
(1,401) \\
(1,564) \\
430\end{array}$ & $\begin{array}{c}(22.68) \\
(20.32) \\
(22.68) \\
6.24\end{array}$ \\
\hline 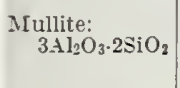 & $\begin{array}{l}16 \\
18 \\
17\end{array}$ & $\begin{array}{l}\mathrm{HP} \\
\mathrm{CP} \\
\mathrm{CP}\end{array}$ & $\begin{array}{l}\text { 2. } 963 \\
\text { 2. } 779 \\
2.771\end{array}$ & $\begin{array}{l}185.0 \\
173.5 \\
173.0\end{array}$ & $\begin{array}{r}(7,840) \\
7,176 \\
7,144\end{array}$ & $\begin{array}{c}(25,720) \\
23,540 \\
23,440\end{array}$ & $\begin{array}{c}(1,819) \\
1,431 \\
1,415\end{array}$ & $\begin{array}{c}(26.38) \\
20.75 \\
20.52\end{array}$ & $\begin{array}{l}704 \\
578 \\
573\end{array}$ & $\begin{array}{r}10.21 \\
8.38 \\
8.31\end{array}$ & $\begin{array}{r}(0.293 \\
.238 \\
.233\end{array}$ & $\begin{array}{r}(1,501) \\
910 \\
883\end{array}$ & $\begin{array}{c}(21.77) \\
13.20 \\
12.81\end{array}$ \\
\hline Mullite $+2 \mathrm{rO}_{2}$ & 22 & $\mathrm{CP}$ & 2. 768 & 172.8 & 6,767 & 22,200 & 1,268 & 18. 39 & 524 & 7.60 & 0.211 & 732 & 10. 62 \\
\hline $\begin{array}{l}\text { Spinel: } \\
\quad \mathrm{MgO} \cdot \mathrm{Al}_{2} \mathrm{O}_{3}\end{array}$ & $\begin{array}{l}20 \\
21\end{array}$ & $\underset{\mathrm{CP}}{\mathrm{HP}}$ & $\begin{array}{l}\text { 3. } 510 \\
2.451\end{array}$ & $\begin{array}{l}219.1 \\
153.0\end{array}$ & $\begin{array}{c}(8,670) \\
5,219\end{array}$ & $\begin{array}{c}(28,440) \\
17,120\end{array}$ & $\begin{array}{c}(2,636) \\
665\end{array}$ & $\begin{array}{c}(38.23) \\
9.64\end{array}$ & $\begin{array}{r}1,019 \\
271\end{array}$ & $\begin{array}{r}14.78 \\
3.93\end{array}$ & $\begin{array}{c}(0.294) \\
.228\end{array}$ & $\begin{array}{c}(2,173) \\
408\end{array}$ & $\begin{array}{l}(31.52) \\
5.92\end{array}$ \\
\hline $\mathrm{ThO}_{2}$ 。 & $\begin{array}{l}10 \\
51\end{array}$ & $\underset{\mathrm{CP}}{\mathrm{CP}}$ & $\begin{array}{l}\text { 9. } 722 \\
9.702\end{array}$ & $\begin{array}{l}606.9 \\
605.7\end{array}$ & $\begin{array}{l}4,972 \\
4,957\end{array}$ & $\begin{array}{l}16.310 \\
16,260\end{array}$ & $\begin{array}{l}2,404 \\
2,384\end{array}$ & $\begin{array}{l}34.87 \\
34.58\end{array}$ & $\begin{array}{l}942 \\
930\end{array}$ & $\begin{array}{l}13.66 \\
13.49\end{array}$ & $\begin{array}{r}0.275 \\
.282\end{array}$ & $\begin{array}{l}1,785 \\
1,819\end{array}$ & $\begin{array}{l}25.89 \\
26.38\end{array}$ \\
\hline $\mathrm{UO}_{2}$ & $\begin{array}{l}19 \\
19 \mathrm{a}\end{array}$ & $\underset{\mathrm{CP}}{\mathrm{CP}}$ & $\begin{array}{l}10.37 \\
10.19\end{array}$ & $\begin{array}{l}647.4 \\
636.1\end{array}$ & $\begin{array}{l}4,314 \\
4,230\end{array}$ & $\begin{array}{l}14,150 \\
13,880\end{array}$ & $\begin{array}{l}1,929 \\
1,823\end{array}$ & $\begin{array}{l}27.98 \\
26.44\end{array}$ & $\begin{array}{l}741 \\
706\end{array}$ & $\begin{array}{l}10.75 \\
10.25\end{array}$ & $\begin{array}{r}0.302 \\
.291\end{array}$ & $\begin{array}{l}1,620 \\
1,457\end{array}$ & $\begin{array}{l}23.50 \\
21.13\end{array}$ \\
\hline $\begin{array}{l}\text { Stabilized } \\
\mathrm{ZrO}_{2}\end{array}$ & $\begin{array}{l}11 \\
13 \\
12\end{array}$ & $\begin{array}{l}\mathrm{HP} \\
\mathrm{CP} \\
\mathrm{CP}\end{array}$ & $\begin{array}{l}5.634 \\
5.149 \\
4.971\end{array}$ & $\begin{array}{l}351.7 \\
321.4 \\
310.3\end{array}$ & $\begin{array}{c}(4,940) \\
5,216 \\
5,481\end{array}$ & $\begin{array}{c}(16,210) \\
17,110 \\
17,980\end{array}$ & $\begin{array}{c}(1,376) \\
1,401 \\
1,493\end{array}$ & $\begin{array}{c}(19.96) \\
20.32 \\
21.65\end{array}$ & $\begin{array}{l}510 \\
585 \\
584\end{array}$ & $\begin{array}{l}7.40 \\
8.48 \\
8.47\end{array}$ & $\begin{array}{c}(0.337) \\
.255 \\
.279\end{array}$ & $\begin{array}{r}f(810) \\
955 \\
1,125\end{array}$ & $\begin{array}{l}(11.75) \\
13.85 \\
16.32\end{array}$ \\
\hline $\mathrm{Al}_{2} \mathrm{O}_{3}+\mathrm{Cr}$ & $\begin{array}{l}29 \\
30 \\
28\end{array}$ & $\begin{array}{l}\text { Cast } \\
\text { Cast } \\
\text { Cast }\end{array}$ & $\begin{array}{l}6.053 \\
5.958 \\
5.691\end{array}$ & $\begin{array}{l}377.9 \\
371.9 \\
355.3\end{array}$ & $\begin{array}{l}6,667 \\
6,787 \\
6,870\end{array}$ & $\begin{array}{l}21,870 \\
22,270 \\
22,540\end{array}$ & $\begin{array}{l}2,690 \\
2,585 \\
2,686\end{array}$ & $\begin{array}{l}39.02 \\
37.49 \\
38.96\end{array}$ & $\begin{array}{l}1,074 \\
1,032 \\
1,114\end{array}$ & $\begin{array}{l}15.58 \\
14.97 \\
16.16\end{array}$ & $\begin{array}{r}0.253 \\
.252 \\
.205\end{array}$ & $\begin{array}{l}1,813 \\
1,732 \\
1,512\end{array}$ & $\begin{array}{l}26.30 \\
25.12 \\
21.93\end{array}$ \\
\hline $\mathrm{TiC}+\mathrm{Ni}$ & $\begin{array}{l}31 \\
32 \\
33 \\
34\end{array}$ & $\begin{array}{l}\mathrm{CP} \\
\mathrm{CP} \\
\mathrm{CP} \\
\mathrm{CP}\end{array}$ & $\begin{array}{l}5.343 \\
5.654 \\
5.862 \\
5.882\end{array}$ & $\begin{array}{l}333.6 \\
353.0 \\
366.0 \\
367.2\end{array}$ & $\begin{array}{l}8,549 \\
8,467 \\
8,023 \\
8,056\end{array}$ & $\begin{array}{l}28,050 \\
27,780 \\
26,320 \\
26,430\end{array}$ & $\begin{array}{l}3,905 \\
4,053 \\
3,773 \\
3,817\end{array}$ & $\begin{array}{l}56.64 \\
58.78 \\
54.72 \\
55.36\end{array}$ & $\begin{array}{l}1,631 \\
1,681 \\
1,560 \\
1,586\end{array}$ & & $\begin{array}{r}0.197 \\
.206 \\
.210 \\
.204\end{array}$ & $\begin{array}{l}2, \mathbf{1} 50 \\
2,295 \\
2, \mathbf{1} 68 \\
2, \mathbf{1 4 7}\end{array}$ & $\begin{array}{l}31.18 \\
33.29 \\
31.44 \\
31.14\end{array}$ \\
\hline $\mathrm{B}_{4} \mathrm{C}$ & 44 & HP & 2.058 & 128.5 & $(14,700)$ & $(48,230)$ & $(4,467)$ & (64. 79) & f $(1,850)$ & 26.83 & f $(0.207)$ & f $(2,542)$ & $(36.87)$ \\
\hline $\mathrm{B}_{1} \mathrm{C}+\mathrm{TiB}_{2}$ & 43 & HP & 2. 816 & 175.8 & $(12,600)$ & $(41,340)$ & $(4,485)$ & $(65.05)$ & f $(1,860)$ & 26.98 & f $(0.206)$ & $(2,539)$ & $(36.82)$ \\
\hline $\mathrm{SiC}$ & $\begin{array}{l}45 \\
35\end{array}$ & $\underset{\mathrm{CP}}{\mathrm{CP}}$ & $\begin{array}{l}\text { 3. } 128 \\
\text { 2. } 596\end{array}$ & $\begin{array}{l}195.3 \\
162.1\end{array}$ & $\begin{array}{r}(11,300) \\
8,744\end{array}$ & $\begin{array}{c}(37,070) \\
28,690\end{array}$ & $\begin{array}{c}(4,013) \\
1,985\end{array}$ & $\begin{array}{c}(58.20) \\
28.79\end{array}$ & $\begin{array}{r}1,683 \\
836\end{array}$ & $\begin{array}{l}24.41 \\
12.12\end{array}$ & $\begin{array}{r}(0.192) \\
.187\end{array}$ & $\begin{array}{r}(966) \\
1,057\end{array}$ & $\begin{array}{l}(14.01) \\
15.33\end{array}$ \\
\hline $\mathrm{SiC}+\mathrm{B}_{ \pm} \mathrm{C}$ & 37 & $\mathrm{HP}$ & 3.082 & 192.4 & $(11,600)$ & $(38,060)$ & $(4,151)$ & $(60.21)$ & f $(1,699)$ & 24.64 & ${ }^{f}(0.221)$ & f $(2,478)$ & (35.94) \\
\hline $\mathrm{ZrC}$ & 38 & HP & 6.118 & 381.9 & $(7,140)$ & $(23,430)$ & $(3,117)$ & $(45.21)$ & 1,240 & 17.98 & $(0.257)$ & $(2,142)$ & 31.07 \\
\hline $\mathrm{ZrB}_{2}$ & $\begin{array}{l}41 \\
42\end{array}$ & $\underset{\mathrm{CP}}{\mathrm{HP}}$ & $\begin{array}{l}5.585 \\
4.557\end{array}$ & $\begin{array}{l}348.7 \\
284.5\end{array}$ & $\begin{array}{l}(8,880) \\
(7,340)\end{array}$ & $\begin{array}{l}(29,130) \\
(24,080)\end{array}$ & $\begin{array}{l}(4,399) \\
(2,455)\end{array}$ & $\begin{array}{l}(63.80) \\
(35.61)\end{array}$ & $\begin{array}{l}1,922 \\
1,085\end{array}$ & $\begin{array}{l}27.88 \\
15.74\end{array}$ & $\begin{array}{r}(0.144) \\
(.131)\end{array}$ & $\begin{array}{l}(2,077) \\
(1,110)\end{array}$ & $\begin{array}{l}(30.12) \\
(16.10)\end{array}$ \\
\hline $\mathrm{MoSi}_{2}$ & 39 & HP & 5.966 & 372.4 & $(7,980)$ & $(26,180)$ & $(3,795)$ & $(55.04)$ & 1,629 & 23.63 & $(0.165)$ & $(1,887)$ & $(27.37)$ \\
\hline $\mathrm{NiAl}$ & 40 & $\mathrm{CP}$ & 5.763 & 359.8 & $(5,620)$ & $(18,440)$ & $(1,817)$ & $(26.35)$ & 723 & 10.49 & $(0.261)$ & $(1,320)$ & $(19.14)$ \\
\hline
\end{tabular}

a When two groups of specimens were available, the average values of the more dense group are given. When three or more groups were available, as with the hot-pressed specimens, the average values of all of the specimens are given.

b The fabrication code used is: $\mathrm{HP}=$ hot-pressed, $\mathrm{CP}=$ cold-pressed and sintered, and Cast = slip-cast and sintered.

c 1 kilobar $=10^{2} \mathrm{dynes} / \mathrm{cm}^{2}=14,503.8 \mathrm{lb} / \mathrm{in}^{2}$

d The accuracy of values in parenthesis is less than that of the other values.

- Contains 12 percent $\mathrm{C} a \mathrm{O}$.

'These values are not considered reliable because of an assumption that was made during the calculation. 
TABLE 7. Data

\begin{tabular}{|c|c|c|c|c|c|c|c|}
\hline \multirow{2}{*}{$\begin{array}{l}\text { Code } \\
\text { and } \\
\text { group }\end{array}$} & \multirow{2}{*}{ Source } & \multirow{2}{*}{$\begin{array}{l}\text { Statistical } \\
\text { parameters }\end{array}$} & \multirow{2}{*}{$\begin{array}{l}\text { No. of } \\
\text { speci- } \\
\text { mens }\end{array}$} & \multirow{2}{*}{ Bulk density } & \multirow{2}{*}{ Speed of sound } & \multicolumn{2}{|c|}{ Young's modulus } \\
\hline & & & & & & $E_{l}$ & $E_{f \omega}$ \\
\hline $1-\mathrm{I}$ & $\mathrm{H}$ & $\begin{array}{c}\text { A verage } \\
\mathrm{V}\end{array}$ & 4 & $\begin{array}{l}3.974 \pm 0.005 \mathrm{~g} / \mathrm{cm}^{3} \\
\left(248.1 \pm 0.3 \mathrm{lb} / \mathrm{ft}^{3}\right) \\
0.1 \%\end{array}$ & & & $\begin{array}{l}3997 \pm 42 \text { kilobars } \\
\left(57.97 \pm 0.61 \times 10^{6} \mathrm{psi}\right) \\
0.7 \%\end{array}$ \\
\hline $1-\mathrm{II}$ & & $\begin{array}{c}\text { Average } \\
\mathrm{V}\end{array}$ & 4 & $\begin{array}{l}3.983 \pm 0.005 \mathrm{~g} / \mathrm{cm}^{3} \\
\left(248.7 \pm 0.3 \mathrm{lb} / \mathrm{ft}^{3}\right) \\
0.1 \%\end{array}$ & & & $\begin{array}{l}4047 \pm 72 \text { kilobars } \\
\left(58.70 \pm 1.04 \times 10^{6} \mathrm{psi}\right) \\
1.1 \%\end{array}$ \\
\hline 1-III & & $\begin{array}{l}\text { A verage } \\
\mathrm{V}\end{array}$ & 2 & $\begin{array}{l}3.980 \pm 0.004 \mathrm{~g} / \mathrm{cm}^{3} \\
\left(248.5 \pm 0.2 \mathrm{lb} / \mathrm{ft}^{3}\right) \\
0.0 \%\end{array}$ & & & $\begin{array}{l}4020 \pm 24 \text { kilobars } \\
\left(58.31 \pm 0.35 \times 10^{6} \mathrm{psi}\right) \\
0.1 \%\end{array}$ \\
\hline $1-I V$ & & $\begin{array}{c}\text { A verage } \\
\mathrm{V}\end{array}$ & 4 & $\begin{array}{l}3.907 \pm 0.063 \mathrm{~g} / \mathrm{cm}^{3} \\
\left(243.9 \pm 3.9 \mathrm{lb} / \mathrm{ft}^{3}\right) \\
1.0 \%\end{array}$ & & & $\begin{array}{l}3916 \pm 104 \text { kilobars } \\
\left(56.80 \pm 1.51 \times 10^{6} \mathrm{psi}\right) \\
1.7 \%\end{array}$ \\
\hline $1-V$ & & $\begin{array}{c}\text { Average } \\
\text { V }\end{array}$ & 4 & $\begin{array}{l}3.876 \pm 0.044 \mathrm{~g} / \mathrm{cm}^{3} \\
\left(241.6 \pm 2.7 \mathrm{lb} / \mathrm{ft}^{3}\right) \\
0.7 \%\end{array}$ & & & $\begin{array}{l}3803 \pm 132 \text { kilobars } \\
\left(55.16 \pm 1.91 \times 10^{8} \mathrm{psi}\right) \\
2.2 \%\end{array}$ \\
\hline $1-\mathrm{VI}$ & & $\begin{array}{l}\text { A verage } \\
\text { V }\end{array}$ & 2 & $\begin{array}{l}3.962 \pm 0.104 \mathrm{~g} / \mathrm{cm}^{3} \\
\left(247.3 \pm 6.5 \mathrm{lb} / \mathrm{ft}^{3}\right) \\
0.3 \%\end{array}$ & & & $\begin{array}{l}4034 \pm 75 \text { kilobars } \\
\left(58.51 \pm 1.09 \times 10^{8} \mathrm{psi}\right) \\
0.2 \%\end{array}$ \\
\hline $1-\mathrm{A} 11$ & & $\begin{array}{c}\text { Average } \\
\text { V }\end{array}$ & 20 & $\begin{array}{l}3.942 \pm 0.021 \mathrm{~g} / \mathrm{cm}^{3} \\
\left(246.1 \pm 1.3 \mathrm{lb} / \mathrm{ft}^{3}\right) \\
1.2 \%\end{array}$ & & & $\begin{array}{l}3958 \pm 48 \text { kilobars } \\
\left.57.41 \pm 0.70 \times 10^{6} \mathrm{psi}\right) \\
2.6 \%\end{array}$ \\
\hline 27 & $\mathrm{G}$ & $\begin{array}{c}\text { Average } \\
\text { V }\end{array}$ & 7 & $\begin{array}{l}3.904 \pm 0.003 \mathrm{~g} / \mathrm{cm}^{3} \\
(243.7 \pm 0.2 \mathrm{lb} / \mathrm{ft})^{3} \\
0.1 \%\end{array}$ & & & $\begin{array}{l}3555 \pm 151 \text { kilobars } \\
\left(51.56 \pm 2.19 \times 10^{6} \mathrm{psi}\right) \\
4.6 \%\end{array}$ \\
\hline $26-\mathrm{I}$ & G & $\begin{array}{c}\text { A verage } \\
\mathrm{V}\end{array}$ & 9 & $\begin{array}{l}3.902 \pm 0.016 \mathrm{~g} / \mathrm{cm}^{3} \\
\left(243.6 \pm 1.0 \mathrm{lb} / \mathrm{ft}^{3}\right) \\
0.5 \%\end{array}$ & & & $\begin{array}{l}3824 \pm 44 \text { kilobars } \\
\left(55.46 \pm 0.64 \times 10^{6} \mathrm{psi}\right) \\
1.4 \%\end{array}$ \\
\hline $26-\mathrm{II}$ & & $\begin{array}{c}\text { Average } \\
\text { V }\end{array}$ & 5 & $\begin{array}{l}3.902 \pm 0.017 \mathrm{~g} / \mathrm{cm}^{3} \\
\left(243.6 \pm 1.1 \mathrm{bb} / \mathrm{ft}^{3}\right) \\
0.3 \%\end{array}$ & & & $\begin{array}{l}3784 \pm 42 \text { kilobars } \\
\left(54.88 \pm 0.61 \times 10^{6} \mathrm{psi}\right) \\
0.7 \%\end{array}$ \\
\hline $4-\mathrm{I}$ & $\mathrm{H}$ & $\begin{array}{c}\text { A verage } \\
\mathrm{V}\end{array}$ & 10 & $\begin{array}{l}3.824 \pm 0.005 \mathrm{~g} / \mathrm{cm}^{3} \\
\left(238.7 \pm 0.3 \mathrm{lb} / \mathrm{ft}^{3}\right) \\
0.2 \%\end{array}$ & $\begin{array}{l}9680 \pm 17.0 \mathrm{~m} / \mathrm{sec} \\
\left(31.76 \pm 0.06 \times 10^{3} \mathrm{ft} / \mathrm{sec}\right) \\
0.2 \%\end{array}$ & $\begin{array}{l}3583 \pm 18.0 \text { kilobars } \\
\left(51.97 \pm 0.26 \times 10^{6} \mathrm{psi}\right) \\
0.7 \%\end{array}$ & $\begin{array}{l}3561 \pm 20 \text { kilobars } \\
\left(51.65 \pm 0.29 \times 10^{6} \mathrm{psi}\right) \\
0.8 \%\end{array}$ \\
\hline 4 -II & 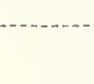 & $\begin{array}{c}\text { Average } \\
\mathrm{V}\end{array}$ & 10 & $\begin{array}{l}3.822 \pm 0.005 \mathrm{~g} / \mathrm{cm}^{3} \\
\left(238.6 \pm 0.3 \mathrm{lb} / \mathrm{ft}^{3}\right) \\
0.2 \%\end{array}$ & $\begin{array}{l}9677 \pm 9.0 \mathrm{~m} / \mathrm{sec} \\
\left(31.75 \pm 0.03 \times 10^{3} \mathrm{ft} / \mathrm{sec}\right) \\
0.1 \%\end{array}$ & $\begin{array}{l}3579 \pm 11.0 \text { kilobars } \\
\left(51.91 \pm 0.16 \times 10^{6} \mathrm{psi}\right) \\
0.4 \%\end{array}$ & $\begin{array}{l}3554 \pm 13 \text { kilobars } \\
\left(51.55 \pm 0.19 \times 10^{6} \mathrm{psi}\right) \\
0.5 \%\end{array}$ \\
\hline 3 & $\mathrm{H}$ & $\begin{array}{c}\text { A verage } \\
\mathrm{V}\end{array}$ & 5 & $\begin{array}{l}3.825 \pm 0.006 \mathrm{~g} / \mathrm{cm}^{3} \\
\left(238.8 \pm 0.4 \mathrm{lb} / \mathrm{ft}^{3}\right) \\
0.1 \%\end{array}$ & $\begin{array}{l}9675 \pm 26.0 \mathrm{~m} / \mathrm{sec} \\
\left(31.74 \pm 0.09 \times 10^{3} \mathrm{ft} / \mathrm{sec}\right) \\
0.2 \%\end{array}$ & $\begin{array}{l}3580 \pm 25.0 \text { kilobars } \\
\left(51.92 \pm 0.36 \times 10^{6} \mathrm{psi}\right) \\
0.6 \%\end{array}$ & $\begin{array}{l}3576 \pm 24 \text { kilobars } \\
\left(51.87 \pm 0.35 \times 10^{5} \mathrm{psi}\right) \\
0.5 \%\end{array}$ \\
\hline $2-\mathrm{I}$ & $\mathrm{H}$ & $\begin{array}{c}\text { A verage } \\
\mathrm{V}\end{array}$ & 10 & $\begin{array}{l}3.714 \pm 0.005 \mathrm{~g} / \mathrm{cm}^{3} \\
\left(231.9 \pm 0.3 \mathrm{~b} / \mathrm{ft}^{3}\right) \\
0.2 \%\end{array}$ & $\begin{array}{l}9361 \pm 18.0 \mathrm{~m} / \mathrm{sec} \\
\left(30.71 \pm 0.06 \times 10^{3} \mathrm{ft} / \mathrm{sec}\right) \\
0.3 \%\end{array}$ & $\begin{array}{l}3255 \pm 16.0 \text { kilobars } \\
\left(47.21 \pm 0.23 \times 10^{6} \mathrm{psi}\right) \\
0.7 \%\end{array}$ & $\begin{array}{l}3260 \pm 22 \text { kilobars } \\
\left(47.28 \pm 0.32 \times 10^{6} \mathrm{psi}\right) \\
1.0 \%\end{array}$ \\
\hline $2-\mathrm{II}$ & & $\begin{array}{c}\text { Average } \\
\text { V }\end{array}$ & 10 & $\begin{array}{l}3.584 \pm 0.014 \mathrm{~g} / \mathrm{cm}^{3} \\
\left(223.7 \pm 0.9 \mathrm{lb} / \mathrm{ft}^{3}\right)^{4} \\
0.6 \%\end{array}$ & $\begin{array}{l}8995 \pm 38.0 \mathrm{~m} / \mathrm{sec} \\
\left(29.51 \pm 0.12 \times 10^{3} \mathrm{ft} / \mathrm{sec}\right) \\
0.6 \%\end{array}$ & $\begin{array}{l}2899 \pm 34.0 \text { kilobars } \\
\left(42.05 \pm 0.49 \times 10^{6} \mathrm{psi}\right) \\
1.7 \%\end{array}$ & $\begin{array}{l}2926 \pm 29 \text { kilobars } \\
\left(42.44 \pm 0.42 \times 10^{6} \mathrm{psi}\right) \\
1.4 \%\end{array}$ \\
\hline 14 & $\mathrm{~F}$ & $\begin{array}{c}\text { A verage } \\
\mathrm{V}\end{array}$ & 12 & $\begin{array}{l}3.470 \pm 0.002 \mathrm{~g} / \mathrm{cm}^{3} \\
\left(216.6 \pm 0.1 \mathrm{bb} / \mathrm{tt}^{3}\right) \\
0.1 \%\end{array}$ & $\begin{array}{l}8676 \pm 8 \mathrm{~m} / \mathrm{sec} \\
\left(28.46 \pm 0.03 \times 10^{3} \mathrm{ft} / \mathrm{sec}\right) \\
0.1 \%\end{array}$ & $\begin{array}{l}2612 \pm 6 \text { kilobars } \\
\left(37.88 \pm 0.09 \times 10^{6} \mathrm{psi}\right) \\
0.4 \%\end{array}$ & $\begin{array}{l}2613 \pm 9 \text { kilobars } \\
\left(37.90 \pm 0.13 \times 10^{6} \mathrm{psi}\right) \\
0.6 \%\end{array}$ \\
\hline 15 & G & $\begin{array}{c}\text { Average } \\
\text { V }\end{array}$ & 8 & $\begin{array}{l}3.332 \pm 0.017 \mathrm{~g} / \mathrm{cm}^{3} \\
\left(208.0 \pm 1.1 \mathrm{lb} / \mathrm{ft}^{3}\right) \\
0.5 \%\end{array}$ & $\begin{array}{l}8349 \pm 93 \mathrm{~m} / \mathrm{sec} \\
\left(27.39 \pm 0.31 \times 10^{3} \mathrm{ft} / \mathrm{sec}\right) \\
1.2 \%\end{array}$ & $\begin{array}{l}2316 \pm 63 \text { kilobars } \\
\left(33.59 \pm 0.91 \times 10^{6} \mathrm{psi}\right) \\
2.9 \%\end{array}$ & $\begin{array}{l}2326 \pm 67 \text { kilobars } \\
\left(33.74 \pm 0.97 \times 10^{6} \mathrm{psi}\right) \\
3.1 \%\end{array}$ \\
\hline 5 & F & A verage & 11 & $\begin{array}{l}2.850 \pm 0.005 \mathrm{~g} / \mathrm{cm}^{3} \\
\left(177.9 \pm 0.3 \mathrm{lb} / \mathrm{ft}^{3}\right) \\
0.3 \%\end{array}$ & $\begin{array}{l}6236 \pm 69 \mathrm{~m} / \mathrm{sec} \\
\left(20.46 \pm 0.23 \times 10^{3} \mathrm{ft} / \mathrm{sec}\right) \\
1.7 \%\end{array}$ & $\begin{array}{l}1109 \pm 25 \text { kilobars } \\
\left(16.08 \pm 0.36 \times 10^{8} \mathrm{psi}\right) \\
3.3 \%\end{array}$ & $\begin{array}{l}1119 \pm 20 \text { kilobars } \\
\left(16.23 \pm 0.29 \times 10^{6} \mathrm{psi}\right) \\
2.7 \%\end{array}$ \\
\hline
\end{tabular}

a Tbe torsional frequency of only one or two specimens could be measured.

$b$ Based on less than 20 specimens.

TABLE 7a. Statistical data for the

\begin{tabular}{|c|c|c|c|c|c|c|}
\hline \multirow{3}{*}{ Code } & \multirow{3}{*}{ Compared groups } & \multirow{3}{*}{$\begin{array}{c}\text { Critical } \\
\text { value }\end{array}$} & \multicolumn{4}{|c|}{$F$ and $t$ values for } \\
\hline & & & \multirow{2}{*}{$\begin{array}{l}\text { Bulk } \\
\text { density }\end{array}$} & \multirow{2}{*}{$\begin{array}{l}\text { Speed of } \\
\text { sound }\end{array}$} & \multicolumn{2}{|c|}{ Yourg's modulus } \\
\hline & & & & & $E_{l}$ & $E_{f w}$ \\
\hline \multirow[t]{2}{*}{26} & $\begin{array}{l}F \text {-test: } \\
\text { I and II }\end{array}$ & 14.6 & 2.98 & & & 3.94 \\
\hline & $\begin{array}{l}t \text {-test: } \\
\text { I and II }\end{array}$ & 2. 23 & 0.03 & & & 1. 29 \\
\hline \multirow[t]{3}{*}{4} & $F$-test: & & & & & \\
\hline & $\begin{array}{l}\text { I and II } \\
t \text {-test: }\end{array}$ & 4.03 & 1.16 & 3.59 & 2. 96 & 2.37 \\
\hline & I and II & 2. 10 & 0.70 & 0.39 & 0.43 & 0.60 \\
\hline \multirow[t]{2}{*}{2} & $\begin{array}{l}F \text {-test: } \\
\text { I and II } \\
t \text {-test: }\end{array}$ & 4.03 & a 8.07 & $\underline{450}$ & $\underline{5.81}$ & 1.73 \\
\hline & I and II & 2. 10 & & & & 20.5 \\
\hline
\end{tabular}

s Underlined figures indicate that a significant difference does exist between the compared groups. 


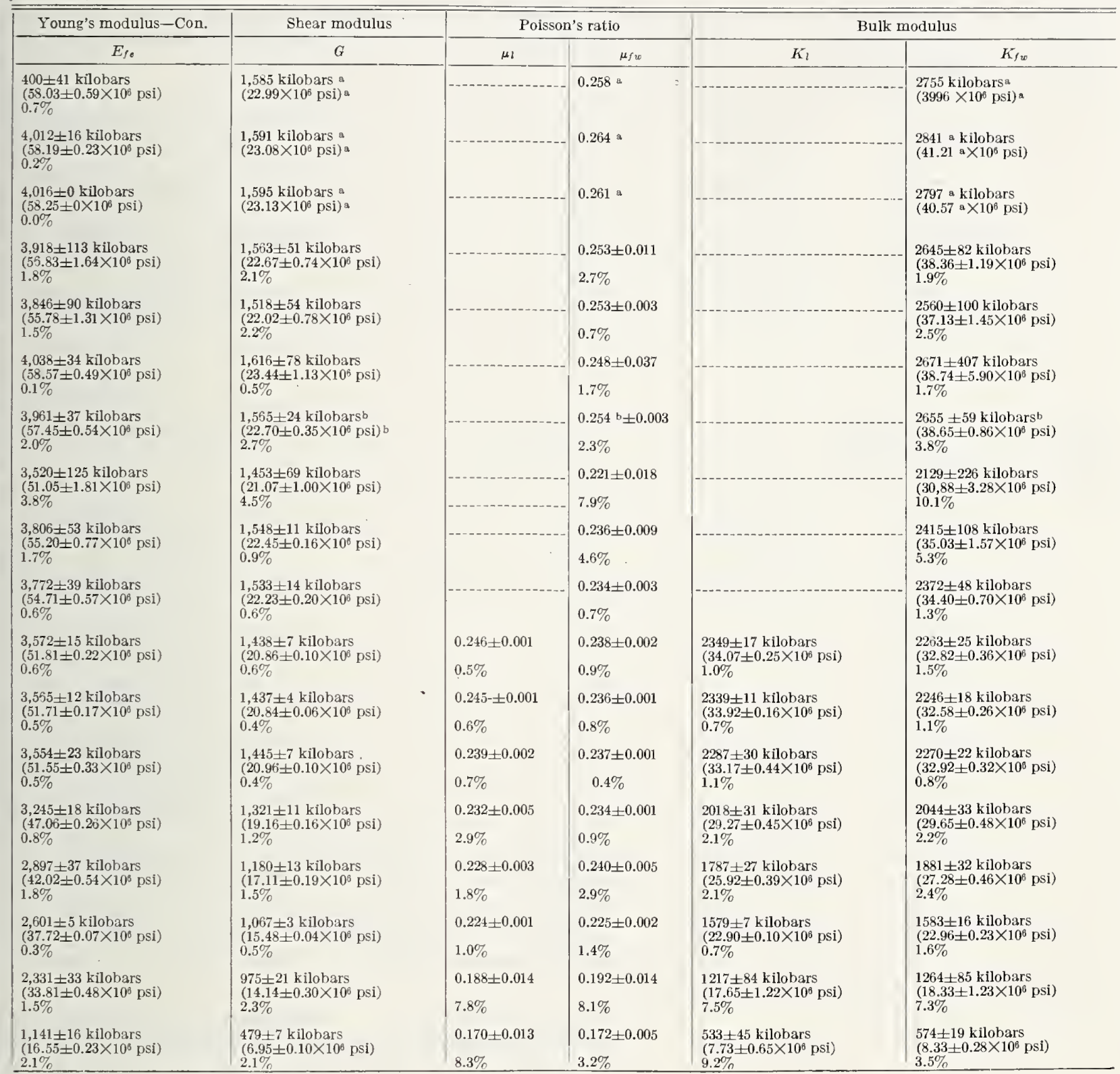

analysis of values given in table 7

\begin{tabular}{|c|c|c|c|c|c|}
\hline \multicolumn{6}{|c|}{$F$ and $t$ values for-Continued } \\
\hline $\begin{array}{l}\text { Young's } \\
\text { modulus- } \\
\text { Continued }\end{array}$ & $\begin{array}{l}\text { Shear } \\
\text { modulus }\end{array}$ & \multicolumn{2}{|c|}{ Poisson's ratio } & \multicolumn{2}{|c|}{ Bulk modulus } \\
\hline$E_{f e}$ & $G$ & $\mu i$ & $\mu f_{w}$ & $K i$ & $K_{f w}$ \\
\hline 6.89 & 2. 17 & & 41.8 & & 18. 2 \\
\hline 0.89 & 0.87 & & & & \\
\hline 1. 62 & 2. 20 & 1.13 & 1.30 & 2. 26 & 2.01 \\
\hline 0.84 & 0.35 & 1.30 & 1.64 & 1.13 & 0.42 \\
\hline$\underline{4.12}$ & 1.35 & 2.80 & 1.15 & 1.37 & 1.05 \\
\hline - n-non & 18.7 & 1.63 & 1.73 & 12.8 & $\underline{8.10}$ \\
\hline
\end{tabular}


TABLE 8. Data

\begin{tabular}{|c|c|c|c|c|c|c|c|}
\hline \multirow{2}{*}{$\begin{array}{l}\text { Code } \\
\text { and } \\
\text { group }\end{array}$} & \multirow{2}{*}{ Source } & \multirow{2}{*}{$\begin{array}{l}\text { Statistical } \\
\text { parameters }\end{array}$} & \multirow{2}{*}{$\begin{array}{l}\text { No. of } \\
\text { speci- } \\
\text { mens }\end{array}$} & \multirow{2}{*}{ Bulk density } & \multirow{2}{*}{ Speed of sound } & \multicolumn{2}{|c|}{ Young's modulus } \\
\hline & & & & & & $E_{i}$ & $E_{j w}$ \\
\hline $6-\mathrm{A}$ & F & $\begin{array}{c}\text { Average } \\
\text { V }\end{array}$ & 5 & $\begin{array}{l}2.780 \pm 0.083 \mathrm{~g} / \mathrm{cm}^{3} \\
\left(173.6 \pm 5.2 \mathrm{lb} / \mathrm{ft}^{3}\right) \\
2.4 \%\end{array}$ & & & $\begin{array}{l}1217 \pm 127 \text { kilobars } \\
\left(17.65 \pm 1.84 \times 10^{8} \mathrm{psi}\right) \\
8.4 \%\end{array}$ \\
\hline $6-\mathrm{B}$ & & $\begin{array}{c}\text { Average } \\
\mathrm{V}\end{array}$ & 5 & $\begin{array}{l}3.728 \pm 0.024 \mathrm{~g} / \mathrm{cm}^{3} \\
\left(232.7 \pm 1.5 \mathrm{lb} / \mathrm{ft}^{3}\right) \\
0.5 \%\end{array}$ & & & $\begin{array}{l}3412 \pm 112 \text { kilobars } \\
\left(49.49 \pm 1.62 \times 10^{6} \mathrm{psi}\right) \\
2.6 \%\end{array}$ \\
\hline $7-A$ & $\mathrm{~F}$ & $\begin{array}{c}\text { A verage } \\
\text { V }\end{array}$ & 5 & $\begin{array}{l}2.682 \pm 0.013 \mathrm{~g} / \mathrm{cm}^{3} \\
\left(167.4 \pm 0.8 \mathrm{lb} / \mathrm{ft}^{3}\right) \\
0.4 \%\end{array}$ & & & $\begin{array}{l}1031 \pm 50 \text { kilobars } \\
\left(14.95 \pm 0.73 \times 10^{8} \mathrm{psi}\right) \\
3.9 \%\end{array}$ \\
\hline $7-\mathrm{B}$ & & $\begin{array}{c}\text { Average } \\
\text { V }\end{array}$ & 5 & $\begin{array}{l}3.661 \pm 0.035 \mathrm{~g} / \mathrm{cm}^{3} \\
\left(228.6 \pm 2.2 \mathrm{lb} / \mathrm{ft}^{3}\right) \\
0.8 \%\end{array}$ & & & $\begin{array}{l}3234 \pm 126 \text { kilobars } \\
\left(46.91 \pm 1.83 \times 10^{6} \mathrm{psi}\right) \\
3.2 \%\end{array}$ \\
\hline
\end{tabular}

TABLE 9. Data

\begin{tabular}{|c|c|c|c|c|c|c|c|}
\hline \multirow{2}{*}{$\begin{array}{l}\text { Code } \\
\text { and } \\
\text { group }\end{array}$} & \multirow{2}{*}{ Source } & \multirow{2}{*}{$\begin{array}{l}\text { Statistical } \\
\text { parametcrs }\end{array}$} & \multirow{2}{*}{$\begin{array}{l}\text { No. of } \\
\text { speci- } \\
\text { mens }\end{array}$} & \multirow{2}{*}{ Bulk density } & \multirow{2}{*}{ Speed of sound } & \multicolumn{2}{|c|}{ Young's modulus } \\
\hline & & & & & & $E_{l}$ & $E_{f w}$ \\
\hline $24-\mathrm{I}$ & G & $\begin{array}{c}\text { Average } \\
\mathrm{V}\end{array}$ & 6 & $\begin{array}{l}3.502 \pm 0.012 \mathrm{~g} / \mathrm{cm}^{3} \\
\left(218.6 \pm 0.7 \mathrm{lb} / \mathrm{ft}^{3}\right) \\
0.3 \%\end{array}$ & & & $\begin{array}{l}2900 \pm 71 \text { kilobars } \\
\left(42.06 \pm 1.03 \times 10^{8} \mathrm{psi}\right) \\
2.3 \%\end{array}$ \\
\hline $24-$ II & -- & $\begin{array}{c}\text { A verage } \\
\mathrm{V}\end{array}$ & 5 & $\begin{array}{l}3.506 \pm 0.006 \mathrm{~g} / \mathrm{cm}^{3} \\
\left(218.9 \pm 0.4 \mathrm{lb} / \mathrm{ft}^{3}\right) \\
0.1 \%\end{array}$ & & & $\begin{array}{l}2947 \pm 22 \text { kilobars } \\
\left(42.74 \pm 0.32 \times 10^{6} \mathrm{psi}\right) \\
0.6 \%\end{array}$ \\
\hline $25-\mathrm{I}$ & $\mathrm{G}$ & $\begin{array}{c}\text { A verage } \\
\mathrm{V}\end{array}$ & 5 & $\begin{array}{l}3.120 \pm 0.021 \mathrm{~g} / \mathrm{cmm}^{3} \\
\left(194.8 \pm 1.3 \mathrm{lb} / \mathrm{ft}^{3}\right) \\
0.7 \%\end{array}$ & & & $\begin{array}{l}2115 \pm 36 \text { kilobars } \\
\left(30.68 \pm 0.52 \times 10^{8} \mathrm{psi}\right) \\
1.8 \%\end{array}$ \\
\hline $25-$ II & -..-. & Average & 9 & $\begin{array}{l}3.483 \pm 0.015 \mathrm{~g} / \mathrm{cm}^{3} \\
\left(217.4 \pm 0.9 \mathrm{lb} / \mathrm{ft}^{3}\right) \\
0.6 \%\end{array}$ & & & $\begin{array}{l}2873 \pm 51 \text { kilobars } \\
\left(41.67 \pm 0.74 \times 10^{6} \mathrm{psi}\right) \\
2.3 \%\end{array}$ \\
\hline $23-A^{a}$ & G & $\begin{array}{c}\text { Average } \\
\mathrm{V}\end{array}$ & 5 & $\begin{array}{l}3.463 \pm 0.034 \mathrm{~g} / \mathrm{cm}^{3} \\
\left(216.2 \pm 2.1 \mathrm{lb} / \mathrm{ft}^{3}\right) \\
0.8 \%\end{array}$ & & & $\begin{array}{l}2832 \pm 115 \text { kilobars } \\
\left(41.07 \pm 1.67 \times 10^{6} \mathrm{psi}\right) \\
3.3 \%\end{array}$ \\
\hline $23-\mathrm{B}^{\mathrm{a}}$ & & $\begin{array}{c}\text { Average } \\
\mathrm{V}\end{array}$ & 5 & $\begin{array}{l}3.479 \pm 0.010 \mathrm{~g} / \mathrm{cm}^{3} \\
\left(217.2 \pm 0.6 \mathrm{lb} / \mathrm{ft}^{3}\right) \\
0.2 \%\end{array}$ & & & $\begin{array}{l}2872 \pm 20 \text { kilobars } \\
\left(41.65 \pm 0.29 \times 10^{6} \mathrm{psi}\right) \\
0.6 \%\end{array}$ \\
\hline $9-\mathrm{I}$ & H & $\begin{array}{c}\text { A verage } \\
\mathrm{V}\end{array}$ & 10 & $\begin{array}{l}2.644 \pm 0.017 \mathrm{~g} / \mathrm{cm}^{3} \\
\left(165.1 \pm 1.1 \mathrm{~b} / \mathrm{ft}^{3}\right) \\
0.9 \%\end{array}$ & $\begin{array}{l}5710 \pm 77 \mathrm{~m} / \mathrm{sec} \\
\left(18.73 \pm 0.25 \times 10^{3} \mathrm{ft} / \mathrm{sec}\right) \\
1.9 \%\end{array}$ & $\begin{array}{l}862 \pm 28 \text { kilobars } \\
\left(12.50 \pm 0.41 \times 10^{\circ} \mathrm{psi}\right) \\
4.6 \%\end{array}$ & $\begin{array}{l}847 \pm 26 \text { kilobars } \\
\left(12.3 \pm 0.4 \times 10^{8} \mathrm{psi}\right) \\
4.3 \%\end{array}$ \\
\hline $9-\mathrm{II}$ & & $\begin{array}{c}\text { Average } \\
\mathrm{V}\end{array}$ & 10 & $\begin{array}{l}2.648 \pm 0.012 \mathrm{~g} / \mathrm{cm}^{3} \\
\left(165.3 \pm 0.7 \mathrm{lb} / \mathrm{ft}^{3}\right) \\
0.7 \%\end{array}$ & $\begin{array}{l}5732 \pm 40 \mathrm{~m} / \mathrm{sec} \\
\left(18.81 \pm 0.13 \times 10^{3} \mathrm{ft} / \mathrm{sec}\right) \\
1.0 \%\end{array}$ & $\begin{array}{l}870 \pm 15 \text { kilobars } \\
\left(12.62 \pm 0.22 \times 10^{6}\right) \\
2.5 \%\end{array}$ & $\begin{array}{l}851 \pm 15 \text { kilobars } \\
\left(12.3 \pm 0.2 \times 10^{6} \mathrm{psi}\right) \\
2.5 \%\end{array}$ \\
\hline
\end{tabular}

a These two sroups were made using different starting:materials.

TABLE 9a. Statistical data for the

\begin{tabular}{|c|c|c|c|c|c|c|}
\hline \multirow{3}{*}{ Code } & \multirow{3}{*}{ Compared groups } & \multirow{3}{*}{$\begin{array}{c}\text { Crítical } \\
\text { value }\end{array}$} & \multicolumn{4}{|c|}{$F$ and $t$ values for } \\
\hline & & & \multirow{2}{*}{$\begin{array}{l}\text { Bulk } \\
\text { density }\end{array}$} & \multirow{2}{*}{$\begin{array}{l}\text { Speed of } \\
\text { sound }\end{array}$} & \multicolumn{2}{|c|}{ Young's modulus } \\
\hline & & & & & $E_{t}$ & $E_{f w}$ \\
\hline \multirow[t]{2}{*}{24} & $F$-test: & 9. 36 & 5. 35 & & & a 14.24 \\
\hline & $t$-test: & & & & & \\
\hline \multirow[t]{2}{*}{25} & $F$-test: & 8.98 & 1.19 & & & 3.04 \\
\hline & $t$-test: & 2. 18 & 832.8 & & & 23.2 \\
\hline \multirow[t]{2}{*}{9} & $F$-test: & 403 & 1.92 & 3.69 & 3.36 & 2.87 \\
\hline & $\begin{array}{l}t \text {-test: } \\
\text { I and II... }\end{array}$ & 2.10 & & 1.70 & 0.98 & 0.83 \\
\hline
\end{tabular}

a Underlined figures indicate that a significant difference does exist between the compared groups. 
TABLE 10. Data for

\begin{tabular}{|c|c|c|c|c|c|c|c|}
\hline \multirow{2}{*}{$\begin{array}{l}\text { Code } \\
\text { and } \\
\text { group }\end{array}$} & \multirow{2}{*}{ Source } & \multirow{2}{*}{$\begin{array}{l}\text { Statistical } \\
\text { parameters }\end{array}$} & \multirow{2}{*}{$\begin{array}{l}\text { No. of } \\
\text { speci- } \\
\text { mens }\end{array}$} & \multirow{2}{*}{ Bulk density } & \multirow{2}{*}{ Speed of sound } & \multicolumn{2}{|c|}{ Young's modulus } \\
\hline & & & & & & $E_{l}$ & $E_{f w}$ \\
\hline $16-I$ & $\mathrm{H}$ & $\begin{array}{c}\text { A verage } \\
\text { V }\end{array}$ & 4 & $\begin{array}{l}2.737 \pm 0.032 \mathrm{~g} / \mathrm{cm}^{3} \\
\left(170.9 \pm 2.0 \mathrm{lb} / \mathrm{ft}^{3}\right) \\
0.7 \%\end{array}$ & & & $\begin{array}{l}1,510 \pm 52 \text { kilobars } \\
\left(21.90 \pm 0.75 \times 10^{8} \mathrm{psi}\right) \\
2.2 \%\end{array}$ \\
\hline $16-$ II & & $\begin{array}{c}\text { Average } \\
\text { V }\end{array}$ & 2 & $\begin{array}{l}2.966 \pm 0.040 \mathrm{~g} / \mathrm{cm}^{3} \\
\left(185.2 \pm 2.5 \mathrm{lb} / \mathrm{ft}^{3}\right) \\
0.2 \%\end{array}$ & & & $\begin{array}{l}1,942 \pm 115 \text { kilobars } \\
\left(28.17 \pm 1.67 \times 10^{8} \mathrm{psi}\right) \\
0.7 \%\end{array}$ \\
\hline $16-I I I$ & 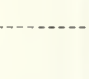 & $\begin{array}{c}\text { Average } \\
\text { V }\end{array}$ & 4 & $\begin{array}{l}3.039 \pm 0.033 \mathrm{~g} / \mathrm{cm}^{3} \\
\left(189.7 \pm 2.1 \mathrm{bb} / \mathrm{ft}^{3}\right) \\
0.7 \%\end{array}$ & & & $\begin{array}{l}1,908 \pm 78 \text { kilobars } \\
\left(27.67 \pm 1.13 \times 10^{6} \mathrm{psi}\right) \\
2.6 \%\end{array}$ \\
\hline $16-I V$ & & $\begin{array}{c}\text { Average } \\
\text { V }\end{array}$ & 5 & $\begin{array}{l}3.041 \pm 0.063 \mathrm{~g} / \mathrm{cm}^{3} \\
\left(189.8 \pm 3.9 \mathrm{lb} / \mathrm{ft}^{3}\right) \\
1.7 \%\end{array}$ & & & $\begin{array}{l}1,911 \pm 97 \text { kilobars } \\
\left(27.72 \pm 1.41 \times 10^{6} \mathrm{psi}\right) \\
4.1 \%\end{array}$ \\
\hline $16-\mathrm{V}$ & & $\begin{array}{c}\text { A verage } \\
\mathrm{V}\end{array}$ & 5 & $\begin{array}{l}3.003 \pm 0.026 \mathrm{~g} / \mathrm{cm}^{3} \\
\left(187.5 \pm 1.6 \mathrm{lb} / \mathrm{it}^{3}\right) \\
0.7 \%\end{array}$ & & & $\begin{array}{l}1,856 \pm 35 \text { kilobars } \\
\left(26.92 \pm 0.51 \times 10^{6} \mathrm{psi}\right) \\
1.5 \%\end{array}$ \\
\hline $16-\mathrm{A} 11$ & & $\begin{array}{c}\text { A verage } \\
\text { V }\end{array}$ & 20 & $\begin{array}{l}2.963 \pm 0.057 \mathrm{~g} / \mathrm{cm}^{3} \\
\left(185.0 \pm 3.6 \mathrm{lb} / \mathrm{ft}^{3}\right) \\
4.1 \%\end{array}$ & & & $\begin{array}{l}1,819 \pm 79 \text { kilobars } \\
\left(26.38 \pm 1.15 \times 10^{8} \mathrm{psi}\right) \\
9.2 \%\end{array}$ \\
\hline 18 a & $\mathrm{F}$ & $\begin{array}{c}\text { Average } \\
\text { V }\end{array}$ & 10 & $\begin{array}{l}2.779 \pm 0.006 \mathrm{~g} / \mathrm{cm}^{3} \\
\left(173.5 \pm 0.4 \mathrm{lb} / \mathrm{ft}^{3}\right) \\
0.3 \%\end{array}$ & $\begin{array}{l}7,176 \pm 11 \mathrm{~m} / \mathrm{sec} \\
\left(23.54 \pm 0.04 \times 10^{3} \mathrm{ft} / \mathrm{sec}\right) \\
0.2 \%\end{array}$ & $\begin{array}{l}1,431 \pm 7 \text { kilobars } \\
\left(20.75 \pm 0.10 \times 10^{8} \mathrm{psi}\right) \\
0.6 \%\end{array}$ & $\begin{array}{l}1,428 \pm 9 \text { kilobars } \\
\left(20.71 \pm 0.13 \times 10^{6} \mathrm{psi}\right) \\
0.9 \%\end{array}$ \\
\hline $17 \mathrm{a}$ & $\mathrm{F}$ & $\begin{array}{c}\text { Average } \\
\mathrm{V}\end{array}$ & 8 & $\begin{array}{l}2.771 \pm 0.008 \mathrm{~g} / \mathrm{cm}^{3} \\
\left(173.0 \pm 0.5 \mathrm{lb} / \mathrm{ft}^{3}\right) \\
0.4 \%\end{array}$ & $\begin{array}{l}7,144 \pm 39 \mathrm{~m} / \mathrm{sec} \\
\left(23.44 \pm 0.13 \times 10^{3} \mathrm{ft} / \mathrm{sec}\right) \\
0.5 \%\end{array}$ & $\begin{array}{l}1,415 \pm 21 \text { kilobars } \\
\left(20.52 \pm 0.30 \times 10^{8} \mathrm{psi}\right) \\
1.4 \%\end{array}$ & $\begin{array}{l}1,420 \pm 21 \text { kilobars } \\
\left(20.60 \pm 0.30 \times 10^{8} \mathrm{psi}\right) \\
1.8 \%\end{array}$ \\
\hline
\end{tabular}

a These two materials, after having been coded and examined, were found to be the same except that Code 18 was heat-treated for a longer time.

TABLE 10a. Statistical data for

\begin{tabular}{|c|c|c|c|c|c|c|}
\hline \multirow{3}{*}{ Code } & \multirow{3}{*}{ Compared groups } & \multirow{3}{*}{$\begin{array}{c}\text { Critical } \\
\text { value }\end{array}$} & \multicolumn{4}{|c|}{$F$ and $t$ values for } \\
\hline & & & \multirow{2}{*}{$\begin{array}{c}\text { Bulk } \\
\text { density }\end{array}$} & \multirow{2}{*}{$\begin{array}{l}\text { Speed of } \\
\text { sound }\end{array}$} & \multicolumn{2}{|c|}{ Young's modulus } \\
\hline & & & & & $E_{l}$ & $E_{f w}$ \\
\hline a $17-18$ & $\begin{array}{l}F \text {-test: } \\
\quad 17 \text { and } 18 \\
t \text {-test: } \\
17 \text { and } 18\end{array}$ & $\begin{array}{r}\mathrm{a} 4.20-4.48^{*} \\
2.12\end{array}$ & 1.43 & a b $5.59^{*}$ & $\underline{5.00^{*}}$ & $\begin{array}{l}3.66 \\
0.09\end{array}$ \\
\hline
\end{tabular}

a $F$ and $t$ values marked with an asterisk indicate comparison with the critical value similarly marked.

b Underlined figures indicate that a significant difference does exist between the compared groups.

TABLE 11. Data

\begin{tabular}{|c|c|c|c|c|c|c|c|}
\hline \multirow{2}{*}{$\begin{array}{l}\text { Code } \\
\text { and } \\
\text { group }\end{array}$} & \multirow{2}{*}{ Source } & \multirow{2}{*}{$\begin{array}{l}\text { Statistical } \\
\text { parameters }\end{array}$} & \multirow{2}{*}{$\begin{array}{l}\text { No. of } \\
\text { speci- } \\
\text { mens }\end{array}$} & \multirow{2}{*}{ Bulk density } & \multirow{2}{*}{ Speed of sound } & \multicolumn{2}{|c|}{ Young's modulus } \\
\hline & & & & & & $E_{l}$ & $E_{f w}$ \\
\hline 22 & $\mathrm{~F}$ & $\begin{array}{c}\text { Average } \\
\text { V }\end{array}$ & 10 & $\begin{array}{l}2.768 \pm 0.010 \mathrm{~g} / \mathrm{cm}^{3} \\
\left(172.8 \pm 0.6 \mathrm{lb} / \mathrm{ft}^{3}\right) \\
0.5 \%\end{array}$ & $\begin{array}{l}6,767 \pm 11 \mathrm{~m} / \mathrm{sec} \\
\left(22.20 \pm 0.04 \times 10^{3} \mathrm{ft} / \mathrm{sec}\right) \\
0.2 \%\end{array}$ & $\begin{array}{l}1,268 \pm 9 \text { kilobars } \\
\left(18.39 \pm 0.13 \times 10^{6} \mathrm{psi}\right) \\
0.9 \%\end{array}$ & $\begin{array}{l}1,265 \pm 9 \text { kilobars } \\
\left(18.35 \pm 0.13 \times 10^{6} \mathrm{psi}\right) \\
1.0 \%\end{array}$ \\
\hline
\end{tabular}


II ullite: $3 \mathrm{Al}_{2} \mathrm{O}_{3} \cdot 2 \mathrm{SiO}_{2}$

\begin{tabular}{|c|c|c|c|c|c|}
\hline \multirow{2}{*}{$\frac{\text { Young's modulus-Con. }}{E_{\text {se }}}$} & Shear modulus & \multicolumn{2}{|c|}{ Poisson's ratio } & \multicolumn{2}{|c|}{ Bulk modulus } \\
\hline & $G$ & $\mu l$ & $\mu \rho w$ & $K_{l}$ & $K_{f \text { to }}$ \\
\hline $\begin{array}{l}1,5.53 \pm 68 \text { kilobars } \\
\left(22.52 \pm 0.99 \times 10^{3} \mathrm{psi}\right) \\
2.8 \%\end{array}$ & $\begin{array}{l}580 \pm 39 \text { kilobars } \\
\left(8.41 \pm 0.57 \times 10^{6} \mathrm{psi}\right) \\
4.2 \%\end{array}$ & & $\begin{array}{l}0.301 \pm 0.049 \\
10 \%\end{array}$ & & $\begin{array}{l}1,244 \pm 258 \text { kilobars } \\
\left(18.04 \pm 3.74 \times 10^{6} \text { psi }\right) \\
13 . \%\end{array}$ \\
\hline $\begin{array}{l}1,992 \pm 50 \text { kilobars } \\
\left(28.39 \pm 0.73 \times 10^{8} \mathrm{psi}\right) \\
0.3 \%\end{array}$ & $\begin{array}{l}731 \pm 33 \text { kilobars } \\
\left(10.6 \pm 0.5 \times 10^{6} \mathrm{psi}\right) \\
0.5 \%\end{array}$ & & $\begin{array}{l}0.327 \pm 0.018 \\
0.6 \%\end{array}$ & & $\begin{array}{l}1,920 \pm 76 \text { kilobars } \\
\left(27.85 \pm 1.10 \times 10^{6} \text { psi }\right) \\
0.4 \%\end{array}$ \\
\hline $\begin{array}{l}1,896 \pm 66 \text { kilobars } \\
\left(27.50 \pm 0.96 \times 10^{\circ} \text { psi }\right) \\
2.2 \%\end{array}$ & $\begin{array}{l}739 \pm 32 \text { kilobars } \\
\left(10 . \overline{7} \pm 0.46 \times 10^{s} \mathrm{psi}\right) \\
2.7 \%\end{array}$ & & $\begin{array}{l}0.291 \pm 0.004 \\
0.8 \%\end{array}$ & & $\begin{array}{l}1,551 \pm 68 \text { kilobars } \\
\left(22.50 \pm 0.99 \times 10^{6} \mathrm{psi}\right) \\
2.7 \%\end{array}$ \\
\hline $\begin{array}{l}1.923 \pm 103 \text { kilobars } \\
\left(27.89 \pm 1.49 \times 10^{3} \text { psi }\right) \\
4.3 \%\end{array}$ & $\begin{array}{l}740 \pm 41 \text { kilobars } \\
\left(10.73 \pm 0.59 \times 10^{8} \text { psi }\right) \\
4.4 \%\end{array}$ & & $\begin{array}{l}0.291 \pm 0.009 \\
2.3 \%\end{array}$ & & $\begin{array}{l}1,525 \pm 86 \text { kilobars } \\
\left(22.12 \pm 1.25 \times 10^{6} \text { psi }\right) \\
4.5 \%\end{array}$ \\
\hline $\begin{array}{l}1,869 \pm 20 \text { kilobars } \\
\left(27.11 \pm 0.29 \times 10^{8} \mathrm{psi}\right) \\
0.9 \%\end{array}$ & $\begin{array}{l}730 \pm 71 \text { kilobars } \\
\left(10.59 \pm 1.03 \times 10^{5} \mathrm{psi}\right) \\
7.8 \%\end{array}$ & & $\begin{array}{l}0.277 \pm 0.092 \\
27 . \%\end{array}$ & & $\begin{array}{l}1,474 \pm 424 \text { kilobars } \\
\left(21.38 \pm 6.15 \times 10^{4} \mathrm{psi}\right) \\
23 . \%\end{array}$ \\
\hline $\begin{array}{l}1.837 \pm 73 \text { kilobars } \\
\left(26.64 \pm 1.06 \times 10^{6} \mathrm{psi}\right) \\
8.5 \%\end{array}$ & $\begin{array}{l}704 \pm 34 \text { kilobars } \\
\left(10.21 \pm 0.49 \times 10^{6} \text { psi) }\right. \\
10.2 \%\end{array}$ & & $\begin{array}{l}0.293 \pm 0.018 \\
13 . \%\end{array}$ & & $\begin{array}{l}1,501 \pm 37 \text { kilobars } \\
\left(21.77 \pm 0.54 \times 10^{6} \text { psi }\right) \\
5.2 \%\end{array}$ \\
\hline $\begin{array}{l}1,425 \pm 7 \text { kilobars } \\
\left(20.67 \pm 0.10 \times 10^{\circ} \text { psi }\right) \\
0.6 \%\end{array}$ & $\begin{array}{l}578 \pm 3 \text { kilobars } \\
\left(8.38 \pm 0.04 \times 10^{6} \mathrm{psi}\right) \\
0.7 \%\end{array}$ & $\begin{array}{l}0.238 \pm 0.002 \\
1.3 \%\end{array}$ & $\begin{array}{l}0.235 \pm 0.003 \\
1.6 \%\end{array}$ & $\begin{array}{l}910 \pm 5 \text { kilobars } \\
\left(13.2 \pm 0.1 \times 10^{6} \text { psi }\right) \\
0.7 \%\end{array}$ & $\begin{array}{l}899 \pm 5 \text { kilobars } \\
\left(13.0 \pm 0.1 \times 10^{6} \text { psi }\right) \\
0.7 \%\end{array}$ \\
\hline $\begin{array}{l}1,409 \pm 14 \text { kilobars } \\
\left(20.44 \pm 0.20 \times 10^{3} \mathrm{psi}\right) \\
1.2 \%\end{array}$ & $\begin{array}{l}573 \pm 7 \text { kilobars } \\
\left(8.31 \pm 0.10 \times 10^{6} \mathrm{psi}\right) \\
1.5 \%\end{array}$ & $\begin{array}{l}0.233 \pm 0.005 \\
2.2 \%\end{array}$ & $\begin{array}{l}0.240 \pm 0.009 \\
4.5 \%\end{array}$ & $\begin{array}{l}883 \pm 15 \text { kilobars } \\
\left(12.8 \pm 0.2 \times 10^{6} \text { psi }\right) \\
2.0 \%\end{array}$ & $\begin{array}{l}911 \pm 39 \text { kilobars } \\
\left(13.2 \pm 0.6 \times 10^{6} \text { psi }\right) \\
5.2 \%\end{array}$ \\
\hline
\end{tabular}

the analysis of values given in table 10

\begin{tabular}{|c|c|c|c|c|c|}
\hline \multicolumn{6}{|c|}{$F$ and $t$ values for - Continued } \\
\hline $\begin{array}{l}\text { Young's } \\
\text { modulus- }\end{array}$ & $\begin{array}{l}\text { Shear } \\
\text { modulus }\end{array}$ & \multicolumn{2}{|c|}{ Poisson's ratio } & \multicolumn{2}{|c|}{ Bulk modulus } \\
\hline$E_{\%}$ 。 & $G$ & $\mu_{l}$ & $\mu f w$ & $K_{t}$ & $K_{f w}$ \\
\hline 3. 38 & 3.80 & 2. $81^{*}$ & 8. $29^{*}$ & $\underline{6.86^{*}}$ & $\underline{51.2}$ \\
\hline$\underline{2.53}$ & 1.87 & $\underline{22.9}$ & & & \\
\hline
\end{tabular}

for mullite plus $\mathrm{ZrO}_{2}$

\begin{tabular}{|c|c|c|c|c|c|}
\hline \multirow{2}{*}{$\frac{\text { Young's modulus-Con. }}{E_{f}}$} & \multirow{2}{*}{$\begin{array}{c}\text { Shear modulus } \\
\qquad G\end{array}$} & \multicolumn{2}{|c|}{ Poisson's ratio } & \multicolumn{2}{|c|}{ Bulk modulus } \\
\hline & & $\mu !$ & $\mu / w$ & $K_{l}$ & $K_{f w}$ \\
\hline $\begin{array}{l}1,273 \pm 9 \text { kilobars } \\
\left(18.46 \pm 0.13 \times 10^{6} \mathrm{psi}\right) \\
1.0 \%\end{array}$ & $\begin{array}{l}524 \pm 4 \text { kilobars } \\
\left(7.60 \pm 0.06 \times 10^{6} \mathrm{psi}\right) \\
0.9 \%\end{array}$ & $\begin{array}{l}0.211 \pm 0.003 \\
1.9 \%\end{array}$ & $\begin{array}{l}0.208 \pm 0.001 \\
0.8 \%\end{array}$ & $\begin{array}{l}732 \pm 8 \text { kilobars } \\
\left(10.62 \pm 0.12 \times 10^{8} \mathrm{psi}\right) \\
1.5 \%\end{array}$ & $\begin{array}{l}724 \pm 11 \text { kilobars } \\
\left(10.50 \pm 0.16 \times 10^{6} \mathrm{psi}\right) \\
2.1 \%\end{array}$ \\
\hline
\end{tabular}


TABLE 12. Data for

\begin{tabular}{|c|c|c|c|c|c|c|c|}
\hline \multirow{2}{*}{$\begin{array}{l}\text { Code } \\
\text { and } \\
\text { group }\end{array}$} & \multirow{2}{*}{ Source } & \multirow{2}{*}{$\begin{array}{l}\text { Statistical } \\
\text { parameters }\end{array}$} & \multirow{2}{*}{$\begin{array}{l}\text { No. of } \\
\text { speci- } \\
\text { mens }\end{array}$} & \multirow{2}{*}{ Bulk density } & \multirow{2}{*}{ Speed of sound } & \multicolumn{2}{|c|}{ Young's modilus } \\
\hline & & & & & & $E_{l}$ & $E_{f w}$ \\
\hline $20-\mathrm{I}$ & $\mathrm{H}$ & $\begin{array}{c}\text { A verage } \\
\mathrm{V}\end{array}$ & 2 & $\begin{array}{l}3.487 \pm 0.084 \mathrm{~g} / \mathrm{cm}^{3} \\
\left(217.7 \pm 5.2 \mathrm{lb} / \mathrm{ft}^{3}\right) \\
0.3 \%\end{array}$ & & & $\begin{array}{l}2,573 \pm 821 \text { kilobars } \\
\left(37.32 \pm 11.91 \times 10^{6} \mathrm{psi}\right) \\
3.6 \%\end{array}$ \\
\hline 20 -II & - & $\begin{array}{c}\text { A verage } \\
\mathrm{V}\end{array}$ & 5 & $\begin{array}{l}3.502 \pm 0.043 \mathrm{~g} / \mathrm{cm}^{3} \\
\left(218.6 \pm 2.3 \mathrm{lb} / \mathrm{ft}^{3}\right) \\
1.0 \%\end{array}$ & & & $\begin{array}{l}2,625 \pm 62 \text { kilobars } \\
\left(38.07 \pm 0.90 \times 10^{6} \mathrm{psi}\right) \\
1.9 \%\end{array}$ \\
\hline $20-$ III & & $\begin{array}{c}\text { A verage } \\
\mathrm{V}\end{array}$ & 4 & $\begin{array}{l}3.539 \pm 0.019 \mathrm{~g} / \mathrm{cm}^{3} \\
\left(220.9 \pm 1.2 \mathrm{lb} / \mathrm{ft}^{3}\right) \\
0.3 \%\end{array}$ & & & $\begin{array}{l}2,685 \pm 116 \text { kilobars } \\
\left(38.94 \pm 1.68 \times 10^{6} \mathrm{psi}\right) \\
2.7 \%\end{array}$ \\
\hline $20-\mathrm{IV}$ & & $\begin{array}{c}\text { A verage } \\
\mathrm{V}\end{array}$ & 5 & $\begin{array}{l}3.533 \pm 0.022 \mathrm{~g} / \mathrm{cm}^{3} \\
\left(220.6 \pm 1.4 \mathrm{lb} / \mathrm{ft}^{3}\right) \\
0.5 \%\end{array}$ & & & $\begin{array}{l}2,674 \pm 45 \text { kilobars } \\
\left(38.78 \pm 0.65 \times 10^{6} \mathrm{psi}\right) \\
1.4 \%\end{array}$ \\
\hline $20-\mathrm{V}$ & & $\begin{array}{c}\text { A verage } \\
\mathrm{V}\end{array}$ & 4 & $\begin{array}{l}3.473 \pm 0.044 \mathrm{~g} / \mathrm{cm}^{3} \\
\left(216.8 \pm 2.7 \mathrm{lb} / \mathrm{ft}^{3}\right) \\
0.8 \%\end{array}$ & & & $\begin{array}{l}2,584 \pm 65 \text { kilobars } \\
\left(37.48 \pm 0.94 \times 10^{6} \mathrm{psi}\right) \\
1.6 \%\end{array}$ \\
\hline 20-All & & $\begin{array}{c}\text { Average } \\
\mathrm{V}\end{array}$ & 20 & $\begin{array}{l}3.510 \pm 0.016 \mathrm{~g} / \mathrm{cm}^{3} \\
\left(219.1 \pm 1.0 \mathrm{lb} / \mathrm{ft}^{3}\right) \\
1.0 \%\end{array}$ & & & $\begin{array}{l}2,636 \pm 31 \text { kilobars } \\
\left(38.23 \pm 0.45 \times 10^{6} \mathrm{psi}\right) \\
2.6 \%\end{array}$ \\
\hline $21-\mathrm{I}$ & H & $\begin{array}{c}\text { A verage } \\
\mathrm{V}\end{array}$ & 8 & $\begin{array}{l}2.451 \pm 0.025 \mathrm{~g} / \mathrm{cm}^{3} \\
\left(153.0 \pm 1.6 \mathrm{lb} / \mathrm{ft}^{3}\right) \\
1.2 \%\end{array}$ & $\begin{array}{l}5,219 \pm 155 \mathrm{~m} / \mathrm{sec} \\
\left(17.12 \pm 0.51 \times 10^{3} \mathrm{ft} / \mathrm{sec}\right) \\
3.6 \%\end{array}$ & $\begin{array}{l}665 \pm 39 \text { kilobars } \\
\left(9.65 \pm 0.57 \times 10^{6} \mathrm{psi}\right) \\
7.1 \%\end{array}$ & $\begin{array}{l}652 \pm 47 \text { kilobars } \\
\left(9.46 \pm 0.68 \times 10^{6} \mathrm{psi}\right) \\
8.6 \%\end{array}$ \\
\hline 21-II & & $\begin{array}{c}\text { A verage } \\
\mathrm{V}\end{array}$ & 10 & $\begin{array}{l}2.522 \pm 0.010 \mathrm{~g} / \mathrm{cm}^{3} \\
\left(157.4 \pm 0.6 \mathrm{lb} / \mathrm{ft}^{3}\right) \\
0.6 \%\end{array}$ & $\begin{array}{l}5,647 \pm 66 \mathrm{~m} / \mathrm{sec} \\
\left(18.53 \pm 0.22 \times 10^{3} \mathrm{ft} / \mathrm{sec}\right) \\
1.6 \%\end{array}$ & $\begin{array}{l}805 \pm 22 \text { kilobars } \\
\left(11.68 \pm 0.32 \times 10^{6} \mathrm{psi}\right) \\
3.7 \%\end{array}$ & $\begin{array}{l}785 \pm 27 \text { kilobars } \\
\left(11.39 \pm 0.39 \times 10^{6} \mathrm{psi}\right) \\
4.8 \%\end{array}$ \\
\hline
\end{tabular}

TABLE 12a. Statistical data for the

\begin{tabular}{|c|c|c|c|c|c|c|}
\hline \multirow{3}{*}{ Code } & \multirow{3}{*}{ Compared groups } & \multirow{3}{*}{$\begin{array}{c}\text { Critical } \\
\text { value }\end{array}$} & \multicolumn{4}{|c|}{$F$ and $t$ values for- } \\
\hline & & & \multirow{2}{*}{$\underset{\text { density }}{\text { Bulk }}$} & \multirow{2}{*}{$\begin{array}{l}\text { Speed of } \\
\text { sound }\end{array}$} & \multicolumn{2}{|c|}{ Young's modulus } \\
\hline & & & & & $E_{l}$ & $E_{f w}$ \\
\hline \multirow[t]{2}{*}{21} & $\begin{array}{l}\text { F-test: } \\
\text { I and II }\end{array}$ & 4. 20 & 4.13 & 4.10 & 2. 46 & 2.22 \\
\hline & $t$-test: & 2. 12 & $\underline{2.85}$ & $\underline{6.42}$ & $\underline{7.64}$ & 6.06 \\
\hline
\end{tabular}

- Underlined figures indicate that a significant difference does exist between the compared groups. 
Spinel: $\mathrm{MgO} \cdot \mathrm{Al}_{2} \mathrm{O}_{3}$

\begin{tabular}{|c|c|c|c|c|c|}
\hline \multirow{2}{*}{$\frac{\text { Young's modulus-Con. }}{E_{f e}}$} & Shear modulus & \multicolumn{2}{|c|}{ Poisson's ratio } & \multicolumn{2}{|c|}{ Bulk modulus } \\
\hline & $G$ & $\mu l$ & $\mu f w$ & $K_{l}$ & $K_{\text {rw }}$ \\
\hline $\begin{array}{l}2,547 \pm 713 \text { kilobars } \\
\left(36.94 \pm 10.34 \times 10^{6} \mathrm{psi}\right) \\
3.1 \%\end{array}$ & $\begin{array}{l}1,017 \pm 71 \text { kilobars } \\
\left(14.75 \pm 1.03 \times 10^{6} \mathrm{psi}\right) \\
0.8 \%\end{array}$ & & $\begin{array}{l}0.265 \\
21 . \%\end{array}$ & & $\begin{array}{l}1,916 \pm 600 \text { kilobars } \\
\left(27.79 \pm 8.70 \times 10^{8} \mathrm{psi}\right) \\
35 . \%\end{array}$ \\
\hline $\begin{array}{l}2,611 \pm 59 \text { kilobars } \\
\left(37.87 \pm 0.86 \times 10^{\circ} \mathrm{psi}\right) \\
1.8 \%\end{array}$ & $\begin{array}{l}1,017 \pm 76 \text { kilobars } \\
\left(14.75 \pm 1.10 \times 10^{6} \mathrm{psi}\right) \\
6.0 \%\end{array}$ & & $\begin{array}{l}0.293 \pm 0.066 \\
18 . \%\end{array}$ & & $\begin{array}{l}2,191 \pm 427 \text { kilobars } \\
\left(31.78 \pm 6.19 \times 10^{6} \mathrm{psi}\right) \\
16 . \%\end{array}$ \\
\hline $\begin{array}{l}2,659 \pm 131 \text { kilobars } \\
\left(38.57 \pm 1.90 \times 10^{6} \text { psi) }\right. \\
3.1 \%\end{array}$ & $\begin{array}{l}1,041 \pm 12 \text { kilobars } \\
\left(15.10 \pm 0.17 \times 10^{6} \mathrm{psi}\right) \\
0.7 \%\end{array}$ & & $\begin{array}{l}0.290 \pm 0.054 \\
12 . \%\end{array}$ & & $\begin{array}{l}2,158 \pm 568 \text { kilobars } \\
\left(31.30 \pm 8.24 \times 10^{6} \mathrm{psi}\right) \\
16 . \%\end{array}$ \\
\hline $\begin{array}{l}2,657 \pm 43 \text { kilobars } \\
\left(39.54 \pm 0.62 \times 10^{8} \text { psi }\right) \\
1.3 \%\end{array}$ & $\begin{array}{l}1,028 \pm 15 \text { kilobars } \\
\left(14.91 \pm 0.22 \times 10^{8} \mathrm{psi}\right) \\
1.2 \%\end{array}$ & & $\begin{array}{l}0.300 \pm 0.008 \\
2.1 \%\end{array}$ & & $\begin{array}{l}2,249 \pm 113 \text { kilobars } \\
\left(32.62 \pm 1.64 \times 10^{3} \mathrm{psi}\right) \\
4.0 \%\end{array}$ \\
\hline $\begin{array}{l}2,619 \pm 54 \text { kilobars } \\
\left(37.99 \pm 0.78 \times 10^{8} \mathrm{psi}\right) \\
1.3 \%\end{array}$ & $\begin{array}{l}990 \pm 26 \text { kilobars } \\
\left(14.36 \pm 0.38 \times 10^{8} \mathrm{psi}\right) \\
1.6 \%\end{array}$ & & $\begin{array}{l}0.305 \pm 0.008 \\
1.6 \%\end{array}$ & & $\begin{array}{l}2,198 \pm 56 \text { kilobars } \\
\left(31.88 \pm 0.81 \times 10^{6} \mathrm{psi}\right) \\
1.6 \%\end{array}$ \\
\hline $\begin{array}{l}2,628 \pm 28 \text { kilobars } \\
\left(38.12 \pm 0.41 \times 10^{\circ} \mathrm{psi}\right) \\
2.3 \%\end{array}$ & $\begin{array}{l}1,019 \pm 16 \text { kilobars } \\
\left(14.78 \pm 0.23 \times 10^{5} \mathrm{psi}\right) \\
3.4 \%\end{array}$ & & $\begin{array}{l}0.294 \pm 0.015 \\
11 . \%\end{array}$ & & $\begin{array}{l}2,173 \pm 132 \text { kilobars } \\
\left(31.52 \pm 1.91 \times 10^{6} \mathrm{psi}\right) \\
13 . \%\end{array}$ \\
\hline $\begin{array}{l}655 \pm 48 \text { kilobars } \\
\left.9.50 \pm 0.70 \times 10^{6} \mathrm{psi}\right) \\
8.8 \%\end{array}$ & $\begin{array}{l}271 \pm 20 \text { kilobars } \\
\left(3.93 \pm 0.29 \times 10^{6} \mathrm{psi}\right) \\
8.8 \%\end{array}$ & $\begin{array}{l}0.228 \pm 0.017 \\
9.0 \%\end{array}$ & $\begin{array}{l}0.202 \pm 0.007 \\
4.2 \%\end{array}$ & $\begin{array}{l}408 \pm 13 \text { kilobars } \\
\left(5.92 \pm 0.19 \times 10^{8} \text { psi }\right) \\
3.7 \%\end{array}$ & $\begin{array}{l}365 \pm 33 \text { kilobars } \\
\left(5.29 \pm 0.48 \times 10^{6} \mathrm{psi}\right) \\
11 . \%\end{array}$ \\
\hline $\begin{array}{l}791 \pm 20 \text { kilobars } \\
\left(11.47 \pm 0.29 \times 10^{6} \mathrm{psi}\right) \\
3.6 \%\end{array}$ & $\begin{array}{l}329 \pm 8 \text { kilobars } \\
\left(4.77 \pm 0.12 \times 10^{6} \text { psi }\right) \\
3.4 \%\end{array}$ & $\begin{array}{l}0.221 \pm 0.008 \\
4.8 \%\end{array}$ & $\begin{array}{l}0.191 \pm 0.030 \\
22 . \%\end{array}$ & $\begin{array}{l}482 \pm 23 \text { kilobars } \\
\left(6.99 \pm 0.33 \times 10^{6} \text { psi) }\right. \\
6.5 \%\end{array}$ & $\begin{array}{l}428 \pm 42 \text { kilobars } \\
\left(6.21 \pm 0.61 \times 10^{6} \mathrm{psi}\right) \\
14 . \%\end{array}$ \\
\hline
\end{tabular}

analysis of values given in table 12

\begin{tabular}{|c|c|c|c|c|c|}
\hline \multicolumn{6}{|c|}{$F$ and $t$ values for - Continued } \\
\hline $\begin{array}{l}\text { Young's } \\
\text { modulus- }\end{array}$ & $\begin{array}{l}\text { Shear } \\
\text { modulus }\end{array}$ & \multicolumn{2}{|c|}{ Poisson's ratio } & \multicolumn{2}{|c|}{ Bulk modulus } \\
\hline$E_{\text {f。 }}$ & $G$ & $\mu !$ & $\mu f$ to & $K_{l}$ & $K_{f \omega}$ \\
\hline$\underline{4.23}$ & $\underline{4.59}$ & 3. 72 & 24.7 & $\underline{4.45}$ & 3.94 \\
\hline$\underline{6.59}$ & & 0.93 & & & $\underline{2.77}$ \\
\hline
\end{tabular}


TABLE $13 .^{a}$

\begin{tabular}{|c|c|c|c|c|c|c|c|}
\hline \multirow{2}{*}{$\begin{array}{l}\text { Code } \\
\text { and } \\
\text { group }\end{array}$} & \multirow{2}{*}{ Source } & \multirow{2}{*}{$\begin{array}{l}\text { Statistical } \\
\text { parameters }\end{array}$} & \multirow{2}{*}{$\begin{array}{l}\text { No. of } \\
\text { speci- } \\
\text { mens }\end{array}$} & \multirow{2}{*}{ Bulk density } & \multirow{2}{*}{ Speed of sound } & \multicolumn{2}{|c|}{ Young's modulus } \\
\hline & & & & & & $E_{l}$ & $E_{f \omega}$ \\
\hline $10-\mathrm{I}$ & $\mathrm{H}$ & $\begin{array}{c}\text { Average } \\
\mathrm{V}\end{array}$ & 9 & $\begin{array}{l}9.722 \pm 0.034 \mathrm{gm} / \mathrm{cm}^{3} \\
\left(606.9 \pm 2.1 \mathrm{gm} / \mathrm{cm}^{3}\right) \\
0.5 \%\end{array}$ & $\begin{array}{l}4,972 \pm 9 \mathrm{~m} / \mathrm{sec} \\
\left(16.31 \pm 0.03 \times 10^{3} \mathrm{ft} / \mathrm{sec}\right) \\
0.2 \%\end{array}$ & $\begin{array}{l}2,404 \pm 13 \text { kilobars } \\
\left(34.87 \pm 0.19 \times 10^{6} \mathrm{psi}\right) \\
0.7 \%\end{array}$ & $\begin{array}{l}2,434 \pm 23 \text { kilobars } \\
\left(35.30 \pm 0.33 \% 10^{6} \mathrm{psi}\right) \\
1.2 \%\end{array}$ \\
\hline 10-II & & $\begin{array}{c}\text { A verage } \\
\text { V }\end{array}$ & 8 & $\begin{array}{l}9.664 \pm 0.012 \mathrm{gm} / \mathrm{cm}^{3} \\
\left(603.3 \pm 0.7 \mathrm{gm} / \mathrm{cm}^{3}\right) \\
0.2 \%\end{array}$ & $\begin{array}{l}4,960 \pm 12 \mathrm{~m} / \mathrm{sec} \\
\left(16.27 \pm 0.04 \times 10^{3} \mathrm{ft} / \mathrm{sec}\right) \\
0.3 \%\end{array}$ & $\begin{array}{l}2,378 \pm 8 \text { kilobars } \\
\left(34.49 \pm 0.12 \times 10^{6} \mathrm{psi}\right) \\
0.4 \%\end{array}$ & $\begin{array}{l}2,406 \pm 18 \text { kilobars } \\
\left(34.90 \pm 0.26 \times 10^{6} \mathrm{psi}\right) \\
0.9 \%\end{array}$ \\
\hline 51 & G & $\begin{array}{c}\text { Average } \\
\text { V }\end{array}$ & 10 & $\begin{array}{l}9.702 \pm 0.008 \mathrm{gm} / \mathrm{cm}^{3} \\
\left(605.7 \pm 0.5 \mathrm{gm} / \mathrm{cm}^{3}\right) \\
0.1 \%\end{array}$ & $\begin{array}{l}4,957 \pm 3 \mathrm{~m} / \mathrm{sec} \\
\left(16.26 \pm 0.01 \times 10^{3} \mathrm{ft} / \mathrm{sec}\right) \\
0.1 \%\end{array}$ & $\begin{array}{l}2,384 \pm 5 \text { kilobars } \\
\left(34.58 \pm 0.07 \times 10^{6} \mathrm{psi}\right) \\
0.3 \%\end{array}$ & $\begin{array}{l}2,395 \pm 6 \text { kilobars } \\
\left(34.74 \pm 0.09 \times 10^{6} \mathrm{psi}\right) \\
0.3 \%\end{array}$ \\
\hline
\end{tabular}

a These compositions contain $1 / 2$ weight percent $\mathrm{CaO}$ as a densifying agent.

TABLE 13-a. Statistical data for the

\begin{tabular}{|c|c|c|c|c|c|c|}
\hline \multirow{3}{*}{ Code } & \multirow{3}{*}{ Compared groups } & \multirow{3}{*}{$\begin{array}{c}\text { Critical } \\
\text { value }\end{array}$} & \multicolumn{4}{|c|}{$F$ and $t$ values for } \\
\hline & & & \multirow{2}{*}{$\underset{\text { density }}{\text { Bulk }}$} & \multirow{2}{*}{$\begin{array}{l}\text { Speed of } \\
\text { sound }\end{array}$} & \multicolumn{2}{|c|}{ Young's modulus } \\
\hline & & & & & $E_{l}$ & $E_{f w}$ \\
\hline 10 & $\begin{array}{l}F \text {-test: } \\
\text { I and II } \\
t \text {-test: } \\
\text { I and II }\end{array}$ & $\begin{array}{l}\text { ․ } 4.90- \\
\text { 4. } 53^{*} \\
2.13\end{array}$ & b $\underline{9.01}$ & $\begin{array}{l}1.38^{*} \\
0.32\end{array}$ & 3. 14 & $\begin{array}{l}1.90 \\
0.37\end{array}$ \\
\hline
\end{tabular}

a $F$ and $t$ values marked with an asterisk indicate comparison with the critical value similarly marked.

$b$ Underlined figures indicate that a significant difference does exist between the compared groups.

TABLE 14

\begin{tabular}{|c|c|c|c|c|c|c|c|}
\hline \multirow{2}{*}{$\begin{array}{l}\text { Code } \\
\text { and } \\
\text { group }\end{array}$} & \multirow{2}{*}{ Source } & \multirow{2}{*}{$\begin{array}{l}\text { Statistical } \\
\text { parameters }\end{array}$} & \multirow{2}{*}{$\begin{array}{l}\text { No. of } \\
\text { speci- } \\
\text { mens }\end{array}$} & \multirow{2}{*}{ Bulk density } & \multirow{2}{*}{ Speed of sound } & \multicolumn{2}{|c|}{ Young's modulus } \\
\hline & & & & & & $E_{l}$ & $E_{f w}$ \\
\hline 19 & $\mathrm{C}$ & $\begin{array}{c}\text { Average } \\
\text { V }\end{array}$ & 5 & $\begin{array}{l}10.368 \pm 0.021 \mathrm{~g} / \mathrm{cm}^{3} \\
\left(647.3 \pm 1.3 \mathrm{lb} / \mathrm{ft}^{3}\right) \\
0.2 \%\end{array}$ & $\begin{array}{l}4,314 \pm 9 \mathrm{~m} / \mathrm{sec} \\
\left(14.15 \pm 0.03 \times 10^{3} \mathrm{ft} / \mathrm{sec}\right) \\
0.2 \%\end{array}$ & $\begin{array}{l}1,929 \pm 10 \text { kilobars } \\
\left(27.98 \pm 0.15 \times 10^{6} \mathrm{psi}\right) \\
0.4 \%\end{array}$ & $\begin{array}{l}1,936 \pm 11 \text { kilobars } \\
\left(28.08 \pm 0.16 \times 10^{6} \mathrm{psi}\right) \\
0.5 \%\end{array}$ \\
\hline $19 \mathrm{a}$ & G & Average & 1 & $\begin{array}{l}10.188 \mathrm{~g} / \mathrm{cm}^{3} \\
\left(636.0 \mathrm{lb} / \mathrm{ft}^{3}\right)\end{array}$ & $\begin{array}{l}4.230 \mathrm{~m} / \mathrm{sec} \\
\left(13.88 \times 10^{3} \mathrm{ft} / \mathrm{sec}\right)\end{array}$ & $\begin{array}{l}1,823 \text { kilobars } \\
\left(26.44 \times 10^{6} \text { psi }\right)\end{array}$ & $\begin{array}{l}1,737 \text { kilobars } \\
\left(25.19 \times 10^{6} \mathrm{psi}\right)\end{array}$ \\
\hline
\end{tabular}


Data for $\mathrm{ThO}_{2}$

\begin{tabular}{|c|c|c|c|c|c|}
\hline Young's modulus-Con. & Shear modulus & \multicolumn{2}{|c|}{ Poisson's ratio } & \multicolumn{2}{|c|}{ Bulk modulus } \\
\hline$E_{f o}$ & $G$ & $\mu l$ & $\mu_{\rho \omega}$ & $K_{l}$ & $K_{f w}$ \\
\hline $\begin{array}{l}2,424 \pm 12 \text { kilobars } \\
\left(35.16 \pm 0.17 \times 10^{\circ} \mathrm{psi}\right) \\
0.6 \%\end{array}$ & $\begin{array}{l}943 \pm 9 \text { kilobars } \\
\left(13.68 \pm 0.13 \times 10^{6} \mathrm{psi}\right) \\
1.2 \%\end{array}$ & $\begin{array}{l}0.275 \pm 0.006 \\
3.0 \%\end{array}$ & $\begin{array}{l}0.291 \pm 0.003 \\
1.4 \%\end{array}$ & $\begin{array}{l}1,785 \pm 46 \text { kilobars } \\
\left(25899 \pm 0.67 \times 10^{6} \mathrm{psi}\right) \\
3.4 \%\end{array}$ & $\begin{array}{l}1,945 \pm 37 \text { kilobars } \\
(2,821 \pm 0.54 \times 106 \mathrm{psi}) \\
2.5 \%\end{array}$ \\
\hline $\begin{array}{l}2,399 \pm 11 \text { kilobars } \\
\left(34.79 \pm 0.16 \times 10^{8} \mathrm{psi}\right) \\
0.5 \%\end{array}$ & $\begin{array}{l}930 \pm 7 \text { kilobars } \\
\left(13.49 \pm 0.10 \times 10^{0} \mathrm{psi}\right) \\
0.9 \%\end{array}$ & $\begin{array}{l}0.279 \pm 0.006 \\
2.7 \%\end{array}$ & $\begin{array}{l}0.294 \pm 0.009 \\
3.6 \%\end{array}$ & $\begin{array}{l}1,793 \pm 48 \text { kilobars } \\
\left(26.01 \pm 0.70 \times 10^{6} \mathrm{psi}\right) \\
3.2 \%\end{array}$ & $\begin{array}{l}1,948 \pm 94 \text { kilobars } \\
\left(28.25 \pm 1.36 \times 10^{8} \mathrm{psi}\right) \\
5.8 \%\end{array}$ \\
\hline $\begin{array}{l}2,384 \pm 3 \text { kilobars } \\
\left(34.58 \pm 0.04 \times 10^{6} \mathrm{psi}\right) \\
0.2 \%\end{array}$ & $\begin{array}{l}930 \pm 3 \text { kilobars } \\
\left(13.49 \pm 0.04 \times 10^{6} \mathrm{psi}\right) \\
0.5 \%\end{array}$ & $\begin{array}{l}0.282 \pm 0.004 \\
1.3 \%\end{array}$ & $\begin{array}{l}0.288 \pm 0.004 \\
2.0 \%\end{array}$ & $\begin{array}{l}1,819 \pm 7 \text { Kilobars } \\
\left(26.38 \pm 0.10 \times 10^{\circ} \mathrm{psi}\right) \\
0.5 \%\end{array}$ & $\begin{array}{l}1,881 \pm 35 \text { kilobars } \\
\left(27.28 \pm 0.51 \times 10^{6} \mathrm{psi}\right) \\
2.6 \%\end{array}$ \\
\hline
\end{tabular}

analysis of values given in table 13

\begin{tabular}{|c|c|c|c|c|c|c|}
\hline \multicolumn{7}{|c|}{$F$ and $t$ values for-Continued } \\
\hline \multirow{2}{*}{$\begin{array}{c}\begin{array}{c}\text { Young's } \\
\text { modulus- } \\
\text { Continued }\end{array} \\
E_{\rho_{\triangleleft}}\end{array}$} & \multirow{2}{*}{$\frac{\begin{array}{c}\text { Shear } \\
\text { modulus }\end{array}}{G}$} & \multicolumn{2}{|c|}{ Poisson's ratio } & \multicolumn{3}{|c|}{ Bulk modulus } \\
\hline & & $\mu_{l}$ & $\mu / \omega$ & & 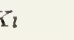 & $K_{f w}$ \\
\hline 1. 47 & 1.95 & 1. 23 & $\underline{5.43^{*}}$ & . & 1.10 & $5.43^{*}$ \\
\hline 0.59 & $\underline{2.72}$ & 0.90 & 0.73 & & 0.27 & \\
\hline
\end{tabular}

Data for $\mathrm{UO}_{2}$

\begin{tabular}{|c|c|c|c|c|c|}
\hline \multirow{2}{*}{$\frac{\text { Young's modulus }- \text { Con. }}{E_{f \bullet}}$} & \multirow{2}{*}{$\begin{array}{c}\text { Shear modulus } \\
G\end{array}$} & \multicolumn{2}{|c|}{ Poisson's ratio } & \multicolumn{2}{|c|}{ Bulk modulus } \\
\hline & & $\mu l$ & $\mu f \omega$ & $K_{l}$ & $K_{f w}$ \\
\hline $\begin{array}{l}1,930 \pm 15 \text { kilobars } \\
\left(27.99 \pm 0.22 \times 10^{3} \mathrm{psi}\right) \\
0.6 \%\end{array}$ & $\begin{array}{l}741 \pm 4 \text { kilobars } \\
\left(10.75 \pm 0.06 \times 10^{6} \mathrm{psi}\right) \\
0.4 \%\end{array}$ & $\begin{array}{l}0.302 \pm 0.003 \\
0.8 \%\end{array}$ & $\begin{array}{l}0.306 \pm 0.003 \\
0.7 \%\end{array}$ & $\begin{array}{l}1.620 \pm 26 \text { kilobars } \\
\left(23.50 \pm 0.38 \times 10^{6} \mathrm{psi}\right) \\
1.3 \%\end{array}$ & $\begin{array}{l}1,662 \pm 30 \text { kilobars } \\
\left(24.11 \pm 0.44 \times 10^{8} \mathrm{psi}\right) \\
1.4 \%\end{array}$ \\
\hline $\begin{array}{l}1,842 \text { kilobars } \\
\left(26.72 \times 10^{6} \mathrm{psi}\right)\end{array}$ & $\begin{array}{l}706 \text { kilobars } \\
\left(10.24 \times 10^{6} \mathrm{psi}\right)\end{array}$ & 0.291 & & $\begin{array}{l}\text { 1,457 kilobars } \\
\left(21.13 \times 10^{6} \mathrm{psi}\right)\end{array}$ & \\
\hline
\end{tabular}


TABLE 15. Data

\begin{tabular}{|c|c|c|c|c|c|c|c|}
\hline \multirow{2}{*}{$\begin{array}{l}\text { Code } \\
\text { and } \\
\text { group }\end{array}$} & \multirow{2}{*}{ Source } & \multirow{2}{*}{$\begin{array}{l}\text { Statistical } \\
\text { parameters }\end{array}$} & \multirow{2}{*}{$\begin{array}{l}\text { No. of } \\
\text { speci- } \\
\text { mens }\end{array}$} & \multirow{2}{*}{ Bulk density } & \multirow{2}{*}{ Speed of sound } & \multicolumn{2}{|c|}{ Young's modulus } \\
\hline & & & & & & $E_{l}$ & $E_{f_{w}}$ \\
\hline $11-1$ & $\mathrm{H}$ & $\begin{array}{c}\text { A verage } \\
\mathrm{V}\end{array}$ & 5 & $\begin{array}{l}5.634 \pm 0.026 \mathrm{~g} / \mathrm{cm}^{3} \\
\left(351.7 \pm 1.6 \mathrm{lb} / \mathrm{ft}^{3}\right) \\
0.4 \%\end{array}$ & & & $\begin{array}{l}1157 \pm 83 \text { kilobars } \\
\left(16.78 \pm 2.65 \times 10^{\circ} \text { psi }\right) \\
5.8 \%\end{array}$ \\
\hline $11-\mathrm{II}$ & & $\begin{array}{c}\text { Average } \\
\mathrm{V}\end{array}$ & 4 & $\begin{array}{l}5.639 \pm 0.027 \mathrm{~g} / \mathrm{cm}^{3} \\
\left(352.0 \pm 1.7 \mathrm{lb} / \mathrm{ft}^{3}\right) \\
0.3 \%\end{array}$ & & & $\begin{array}{l}1072 \pm 44 \text { kilobars } \\
\left(15.55 \pm 0.64 \times 10^{6} \mathrm{psi}\right) \\
2.6 \%\end{array}$ \\
\hline $11-I I I$ & & $\begin{array}{c}\text { Average } \\
\text { V }\end{array}$ & 5 & $\begin{array}{l}5.654 \pm 0.045 \mathrm{~g} / \mathrm{cm}^{3} \\
\left(353.0 \pm 2.8 \mathrm{lb} / \mathrm{ft}^{3}\right) \\
0.6 \%\end{array}$ & & & $\begin{array}{l}2051 \pm 81 \text { kilobars } \\
\left(29.75 \pm 1.17 \times 10^{6} \mathrm{psi}\right) \\
3.2 \%\end{array}$ \\
\hline $11-I V$ & & $\begin{array}{l}\text { Averagc } \\
\mathrm{V}\end{array}$ & 4 & $\begin{array}{l}5.603 \pm 0.024 \mathrm{~g} / \mathrm{cm}^{3} \\
\left(349.8 \pm 1.5 \mathrm{lb} / \mathrm{ft}^{3}\right) \\
0.3 \%\end{array}$ & & & $\begin{array}{l}1111 \pm 385 \text { kilobars } \\
\left(16.11 \pm 5.58 \times 10^{6} \mathrm{psi}\right) \\
22 \%\end{array}$ \\
\hline 11-All & & $\begin{array}{c}\text { Average } \\
\mathrm{V}\end{array}$ & 18 & $\begin{array}{l}5.634 \pm 0.015 \mathrm{~g} / \mathrm{cm}^{3} \\
\left(351.7 \pm 0.9 \mathrm{bb} / \mathrm{ft}^{3}\right) \\
0.5 \%\end{array}$ & & & $\begin{array}{l}1376 \pm 222 \text { kilobars } \\
\left(19.96 \pm 3.22 \times 10^{6} \mathrm{psi}\right) \\
32 \%\end{array}$ \\
\hline $\begin{array}{l}13-\mathrm{I} \\
1\end{array}$ & $\mathrm{H}$ & $\begin{array}{c}\text { A verage } \\
\mathrm{V}\end{array}$ & 10 & $\begin{array}{l}5.149 \pm 0.016 \mathrm{~g} / \mathrm{cm}^{3} \\
\left(321.4 \pm 1.0 \mathrm{lb} / \mathrm{ft}^{3}\right) \\
0.4 \%\end{array}$ & $\begin{array}{l}5216 \pm 51 \mathrm{~m} / \mathrm{sec} \\
\left(17.11 \pm 0.17 \times 10^{3} \mathrm{ft} / \mathrm{sec}\right) \\
1.4 \%\end{array}$ & $\begin{array}{l}1401 \pm 23 \text { kilobars } \\
\left(20.32 \pm 0.33 \times 10^{6} \mathrm{psi}\right) \\
2.3 \%\end{array}$ & $\begin{array}{l}1391 \pm 26 \text { kilobars } \\
\left(20.17 \pm 0.38 \times 10^{6} \mathrm{psi}\right) \\
2.6 \%\end{array}$ \\
\hline $13-\mathrm{IX}$ & & $\begin{array}{c}\text { Average } \\
\mathrm{V}\end{array}$ & 10 & $\begin{array}{l}5.162 \pm 0.013 \mathrm{~g} / \mathrm{cm}^{3} \\
\left(322.3 \pm 0.8 \mathrm{lb} / \mathrm{ft}^{3}\right) \\
0.4 \%\end{array}$ & $\begin{array}{l}4950 \pm 184 \mathrm{~m} / \mathrm{sec} \\
\left(16.24 \pm 0.60 \times 10^{3} \mathrm{ft} / \mathrm{sec}\right) \\
5.1 \%\end{array}$ & $\begin{array}{l}1268 \pm 93 \text { kilobars } \\
\left(18.39 \pm 1.35 \times 10^{6} \mathrm{psi}\right) \\
10.3 \%\end{array}$ & $\begin{array}{l}1269 \pm 92 \text { kilobars } \\
\left(18.41 \pm 1.33 \times 10^{6} \mathrm{psi}\right) \\
10.1 \%\end{array}$ \\
\hline $12-\mathrm{I}$ & $\mathrm{H}$ & $\begin{array}{c}\text { Average } \\
\mathrm{V}\end{array}$ & 10 & $\begin{array}{l}4.967 \pm 0.017 \mathrm{~g} / \mathrm{cm}^{3} \\
\left(310.1 \pm 1.1 \mathrm{lb} / \mathrm{ft}^{3}\right) \\
0.5 \%\end{array}$ & $\begin{array}{l}5456 \pm 20 \mathrm{~m} / \mathrm{sec} \\
\left(17.90 \pm 0.07 \times 10^{3} \mathrm{ft} / \mathrm{sec}\right) \\
0.5 \%\end{array}$ & $\begin{array}{l}1478 \pm 15 \text { kilobars } \\
\left(21.44 \pm 0.22 \times 10^{6} \mathrm{psi}\right) \\
1.4 \%\end{array}$ & $\begin{array}{l}1483 \pm 15 \text { kilobars } \\
\left(21.51 \pm 0.22 \times 10^{6} \mathrm{psi}\right) \\
1.4 \%\end{array}$ \\
\hline $12-\mathrm{II}$ & & $\begin{array}{c}\text { Average } \\
\qquad\end{array}$ & 10 & $\begin{array}{l}4.971 \pm 0.011 \mathrm{~g} / \mathrm{cm}^{3} \\
\left(310.3 \pm 0.7 \mathrm{lb} / \mathrm{ft}^{3}\right) \\
0.3 \%\end{array}$ & $\begin{array}{l}5481 \pm 10 \mathrm{~m} / \mathrm{sec} \\
\left(17.98 \pm 0.03 \times 10^{3} \mathrm{ft} / \mathrm{sec}\right) \\
0.3 \%\end{array}$ & $\begin{array}{l}1493 \pm 8 \text { kilobars } \\
\left(21.65 \pm 0.12 \times 10^{6} \mathrm{psi}\right) \\
0.8 \%\end{array}$ & $\begin{array}{l}1499 \pm 10 \text { kilobars } \\
\left(21.74 \pm 0.15 \times 10^{6} \mathrm{psi}\right) \\
1.0 \%\end{array}$ \\
\hline
\end{tabular}

a This composition contains about 5 wt $\%$ of $\mathrm{CaO}$ as the stabilizing agent.

$b$ Because of the very high and diverse values calculated for Poisson's ratio, the calculated bulk modulus values have little significance.

TABle 15a. Statistical data for the

\begin{tabular}{|c|c|c|c|c|c|c|}
\hline \multirow{3}{*}{ Codc } & \multirow{3}{*}{ Compared groups } & \multirow{3}{*}{$\begin{array}{l}\text { Critical } \\
\text { value }\end{array}$} & \multicolumn{4}{|c|}{$F$ and $t$ values for } \\
\hline & & & \multirow{2}{*}{$\begin{array}{l}\text { Bulk } \\
\text { density }\end{array}$} & \multirow{2}{*}{$\begin{array}{l}\text { Speed of } \\
\text { sound }\end{array}$} & \multicolumn{2}{|c|}{ Young's modulus } \\
\hline & & & & & $E_{l}$ & $E_{f w}$ \\
\hline \multirow[t]{2}{*}{13} & $\begin{array}{l}F \text {-test: } \\
\text { I and II } \\
t \text {-test: }\end{array}$ & 4. 03 & 1.51 & 8 13.2 & 15.9 & 12.4 \\
\hline & I and II & 2. 10 & 1.48 & & & \\
\hline \multirow[t]{2}{*}{12} & $F$-test: & 4.03 & 2.58 & 3.95 & 3.15 & 2.04 \\
\hline & I and II & 2.10 & 1.56 & 2.46 & 1.98 & 2.02 \\
\hline
\end{tabular}

a Underlined figures indicate that a significant difference does exist between the compared groups. 
for "stabilized" $\mathrm{ZrO}_{2}{ }^{\text {a }}$

\begin{tabular}{|c|c|c|c|c|c|}
\hline Young's modulus-Con. & Shear modulu & \multicolumn{2}{|c|}{ Poisson's ratio } & \multicolumn{2}{|c|}{ Bulk modulus } \\
\hline$E_{f 0}$ & $G$ & $\mu_{l}$ & $\mu f w$ & $\boldsymbol{K}_{l}$ & $K_{f w}$ \\
\hline $\begin{array}{l}1202 \pm 80 \text { kilobars } \\
\left(17.43 \pm 1.16 \times 10^{8} \mathrm{psi}\right) \\
5.4 \%\end{array}$ & $\begin{array}{l}455 \pm 39 \text { kilobars } \\
\left(6.60 \pm 0.57 \times 10^{6} \mathrm{psi}\right) \\
6.9 \%\end{array}$ & - & $\begin{array}{l}0.274 \pm 0.022 \\
6.4 \%\end{array}$ & & $\begin{array}{l}857 \pm 43 \text { kilobars } \\
\left(12.43 \pm 0.62 \times 10^{6} \mathrm{psi}\right) \\
4.0 \%\end{array}$ \\
\hline $\begin{array}{l}1122 \pm 58 \text { kilobars } \\
\left(16.27 \pm 0.81 \times 10^{6} \mathrm{psi}\right) \\
3.2 \%\end{array}$ & $\begin{array}{l}423 \pm 13 \text { kilobars } \\
\left(6.14 \pm 0.19 \times 10^{6} \mathrm{psi}\right) \\
2.0 \%\end{array}$ & & $\begin{array}{l}0.268 \pm 0.02 \\
4.6 \%\end{array}$ & & $\begin{array}{l}772 \pm 93 \text { kilobars } \\
(11.20 \pm 1.33 \times \mathrm{psi}) \\
7.5 \%\end{array}$ \\
\hline $\begin{array}{l}2031 \pm 68 \text { kilobars } \\
\left(29.46 \pm 0.99 \times 10^{6} \mathrm{psi}\right) \\
2.7 \%\end{array}$ & $\begin{array}{l}725 \pm 48 \text { kilobars } \\
\left(10.52 \pm 0.70 \times 10^{6} \mathrm{psi}\right) \\
5.3 \%\end{array}$ & 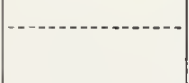 & $\begin{array}{l}0.416 \pm 0.052 \\
10.1 \%\end{array}$ & $-\cdots$ & (b) \\
\hline $\begin{array}{l}1132 \pm 372 \text { kilobars } \\
\left(16.42 \pm 5.40 \times 10^{6} \text { psi }\right) \\
21 \%\end{array}$ & $\begin{array}{l}398 \pm 70 \text { kilobars } \\
\left(5.77 \pm 1.02 \times 10^{6} \mathrm{psi}\right) \\
11.0 \%\end{array}$ & & $\begin{array}{l}0.386 \pm 0.218 \\
36 \%\end{array}$ & & $(b)$ \\
\hline $\begin{array}{l}1399 \pm 208 \text { kilobars } \\
\left(20.29 \pm 3.02 \times 10^{6} \mathrm{psi}\right) \\
30 \%\end{array}$ & $\begin{array}{l}510 \pm 71 \text { kilobars } \\
\left(7.40 \pm 1.03 \times 10^{\circ} \mathrm{psi}\right) \\
28 \%\end{array}$ & & $\begin{array}{l}0.337 \pm 0.046^{b} \\
27 \%\end{array}$ & & (b) \\
\hline $\begin{array}{l}1394 \pm 22 \text { kilobars } \\
\left(20.22 \pm 0.32 \times 10^{\circ} \mathrm{psi}\right) \\
2.2 \%\end{array}$ & $\begin{array}{l}558 \pm 7 \text { kilobars } \\
\left(8.09 \pm 0.10 \times 10^{8} \mathrm{psi}\right) \\
1.9 \%\end{array}$ & $\begin{array}{l}0.255 \pm 0.006 \\
3.3 \%\end{array}$ & $\begin{array}{l}0.246 \pm 0.008 \\
4.6 \%\end{array}$ & $\begin{array}{l}955 \pm 37 \text { kilobars } \\
\left(13.85 \pm 0.54 \times 10^{6} \mathrm{psi}\right) \\
5.3 \%\end{array}$ & $\begin{array}{l}906 \pm 59 \text { kilobars } \\
\left(13.14 \pm 0.86 \times 10^{6} \mathrm{psi}\right) \\
9.1 \%\end{array}$ \\
\hline $\begin{array}{l}1259 \pm 94 \text { kilobars } \\
\left(18.20 \pm 1.36 \times 10^{\circ} \mathrm{psi}\right) \\
10.5 \%\end{array}$ & $\begin{array}{l}514 \pm 33 \text { kilobars } \\
\left(7.45 \pm 0.48 \times 10^{3} \mathrm{psi}\right) \\
9.1 \%\end{array}$ & $\left\{\begin{array}{l}0.232 \pm 0.012 \\
7.0 \%\end{array}\right.$ & $\begin{array}{l}0.234 \pm 0.010 \\
6.2 \%\end{array}$ & $\begin{array}{l}796 \pm 92 \text { kilobars } \\
\left(11.54 \pm 1.33 \times 10^{6} \text { psi }\right) \\
16 \%\end{array}$ & $\begin{array}{l}802 \pm 87 \text { kilobars } \\
\left(11.63 \pm 1.26 \times 10^{6} \mathrm{psi}\right) \\
15 \%\end{array}$ \\
\hline $\begin{array}{l}1479 \pm 12 \text { kilobars } \\
\left(21.45 \pm 0.17 \times 10^{8} \mathrm{psi}\right) \\
1.2 \%\end{array}$ & $\begin{array}{l}575 \pm 6 \text { kilobars } \\
\left(8.34 \pm 0.09 \times 10^{6} \mathrm{psi}\right) \\
1.4 \%\end{array}$ & $\begin{array}{l}0.285 \pm 0.005 \\
2.6 \%\end{array}$ & $\begin{array}{l}0.289 \pm 0.005 \\
2.4 \%\end{array}$ & $\begin{array}{l}1144 \pm 26 \text { kilobars } \\
\left(16.59 \pm 0.38 \times 10^{6} \mathrm{psi}\right) \\
3.2 \%\end{array}$ & $\begin{array}{l}1168 \pm 12 \text { kilobars } \\
\left(16.94 \pm 0.17 \times 10^{6} \mathrm{ps} 1\right) \\
1.4 \%\end{array}$ \\
\hline $\begin{array}{l}1492 \pm 10 \text { kilobars } \\
\left(21.64 \pm 0.15 \times 10^{6} \text { psi }\right) \\
0.9 \%\end{array}$ & $\begin{array}{l}584 \pm 4 \text { kilobars } \\
\left(8.47 \pm 0.06 \times 10^{8} \mathrm{psi}\right) \\
1.0 \%\end{array}$ & $\begin{array}{l}0.279 \pm 0.002 \\
1.1 \%\end{array}$ & $\begin{array}{l}0.284 \pm 0.002 \\
0.8 \%\end{array}$ & $\begin{array}{l}1125 \pm 11 \text { kilobars } \\
\left(16.32 \pm 0.16 \times 10^{6} \mathrm{psi}\right) \\
1.4 \%\end{array}$ & $\begin{array}{l}1157 \pm 30 \text { kilobars } \\
\left(16.78 \pm 0.44 \times 10^{6} \mathrm{psi}\right) \\
3.6 \%\end{array}$ \\
\hline
\end{tabular}

analysis of values given in table 15

\begin{tabular}{|c|c|c|c|c|c|}
\hline \multicolumn{6}{|c|}{$F$ and $t$ values for-Continued } \\
\hline Young's & $\begin{array}{l}\text { Shear } \\
\text { modulus }\end{array}$ & \multicolumn{2}{|c|}{ Polsson's ratio } & \multicolumn{2}{|c|}{ Bulk modulus } \\
\hline$E_{f e}$ & $G$ & $\mu l$ & $\mu \rho_{\omega}$ & $K_{l}$ & $K_{f w}$ \\
\hline 19.1 & 20.2 & 3.83 & 1.64 & 6.41 & 2. 19 \\
\hline & & 3. 90 & 2.07 & & $\underline{2.24}$ \\
\hline 1. 57 & 2.08 & 5.31 & 1. 08 & 5. 94 & 6.67 \\
\hline 1.88 & 2.65 & & 1.53 & & \\
\hline
\end{tabular}


TABLE 16. Data

\begin{tabular}{|c|c|c|c|c|c|c|c|}
\hline \multirow{2}{*}{$\begin{array}{l}\text { Code } \\
\text { and } \\
\text { group }\end{array}$} & \multirow{2}{*}{ Source } & \multirow{2}{*}{$\begin{array}{l}\text { Statistical } \\
\text { parameters }\end{array}$} & \multirow{2}{*}{$\begin{array}{l}\text { No. of } \\
\text { speci- } \\
\text { mens }\end{array}$} & \multirow{2}{*}{ Bulk density } & \multirow{2}{*}{ Speed of sound } & \multicolumn{2}{|c|}{ Young's modulus } \\
\hline & & & & & & $E_{l}$ & $E_{f w}$ \\
\hline 29 & $\mathrm{D}$ & $\begin{array}{c}\text { Average } \\
\mathrm{V}\end{array}$ & 19 & $\begin{array}{l}6.053 \pm 0.021 \mathrm{~g} / \mathrm{cm}^{3} \\
\left(377.9 \pm 1.3 \mathrm{lb} / \mathrm{ft}^{3}\right) \\
0.7 \%\end{array}$ & $\begin{array}{l}6667 \pm 22 \mathrm{~m} / \mathrm{sec} \\
\left(21.87 \pm 0.07 \times 10^{3} \mathrm{ft} / \mathrm{sec}\right) \\
0.7 \%\end{array}$ & $\begin{array}{l}2690 \pm 25 \text { kilobars } \\
\left(39.01 \pm 0.36 \times 10^{6} \mathrm{psi}\right) \\
1.9 \%\end{array}$ & $\begin{array}{l}2711 \pm 19 \text { kilobars } \\
\left(39.32 \pm 0.28 \times 10^{8} \mathrm{psi}\right) \\
1.5 \%\end{array}$ \\
\hline $30-\mathrm{I}$ & $D$ & $\begin{array}{c}\text { Average } \\
\text { V }\end{array}$ & 10 & $\begin{array}{l}5.958 \pm 0.017 \mathrm{~g} / \mathrm{cm}^{3} \\
\left(371.9 \pm 1.1 \mathrm{lb} / \mathrm{ft}^{3}\right) \\
0.4 \%\end{array}$ & $\begin{array}{l}6587 \pm 18 \mathrm{~m} / \mathrm{sec} \\
\left(21.61 \pm 0.06 \times 10^{3} \mathrm{ft} / \mathrm{sec}\right) \\
0.4 \%\end{array}$ & $\begin{array}{l}2585 \pm 21 \text { kilobars } \\
\left(37.49 \pm 0.30 \times 10^{6} \mathrm{psi}\right) \\
1.1 \%\end{array}$ & $\begin{array}{l}2611 \pm 25 \text { kilobars } \\
\left(37.87 \pm 0.36 \times 10^{8} \mathrm{psi}\right) \\
1.4 \%\end{array}$ \\
\hline $30-\mathrm{II}$ & & $\begin{array}{c}\text { A verage } \\
\mathrm{V}\end{array}$ & 10 & $\begin{array}{l}5.944 \pm 0.015 \mathrm{~g} / \mathrm{cm}^{3} \\
\left(371.1 \pm 0.9 \mathrm{lb} / \mathrm{ft}^{3}\right) \\
0.4 \%\end{array}$ & $\begin{array}{l}6563 \pm 11 \mathrm{~m} / \mathrm{sec} \\
\left(21.53 \pm 0.04 \times 10^{3} \mathrm{ft} / \mathrm{sec}\right) \\
0.2 \%\end{array}$ & $\begin{array}{l}2560 \pm 15 \text { kilobars } \\
\left(37.13 \pm 0.22 \times 10^{6} \mathrm{psi}\right) \\
0.8 \%\end{array}$ & $\begin{array}{l}2589 \pm 17 \text { kilobars } \\
\left(37.55 \pm 0.25 \times 10^{\circ} \mathrm{psi}\right) \\
0.9 \%\end{array}$ \\
\hline $28-\mathrm{I}$ & $\mathrm{D}$ & $\begin{array}{c}\text { A verage } \\
\mathrm{V}\end{array}$ & 10 & $\begin{array}{l}5.691 \pm 0.006 \mathrm{~g} / \mathrm{cm}^{3} \\
\left(355.3 \pm 0.4 \mathrm{lb} / \mathrm{ft}^{3}\right) \\
0.2 \%\end{array}$ & $\begin{array}{l}6870 \pm 12 \mathrm{~m} / \mathrm{sec} \\
\left(22.54 \pm 0.04 \times 10^{3} \mathrm{ft} / \mathrm{sec}\right) \\
0.2 \%\end{array}$ & $\begin{array}{l}2686 \pm 12 \text { kilobars } \\
\left(38.96 \pm 0.17 \times 10^{6} \mathrm{psi}\right) \\
0.6 \%\end{array}$ & $\begin{array}{l}2713 \pm 20 \text { kilobars } \\
\left(39.35 \pm 0.29 \times 10^{6} \mathrm{psi}\right) \\
1.0 \%\end{array}$ \\
\hline 28-II & & $\begin{array}{c}\text { Average } \\
\text { V }\end{array}$ & 10 & $\begin{array}{l}5.564 \pm 0.041 \mathrm{~g} / \mathrm{cm}^{3} \\
\left(347.4 \pm 2.6 \mathrm{lb} / \mathrm{ft}^{3}\right) \\
1.0 \%\end{array}$ & $\begin{array}{l}6712 \pm 47 \mathrm{~m} / \mathrm{sec} \\
\left(22.02 \pm 0.15 \times 10^{3} \mathrm{ft} / \mathrm{sec}\right) \\
1.0 \%\end{array}$ & $\begin{array}{l}2507 \pm 53 \text { kilobars } \\
\left(36.36 \pm 0.77 \times 10^{6} \mathrm{psi}\right) \\
2.9 \%\end{array}$ & $\begin{array}{l}2543 \pm 56 \text { kilobars } \\
\left(36.88 \pm 0.81 \times 10^{8} \mathrm{psi}\right) \\
3.1 \%\end{array}$ \\
\hline
\end{tabular}

- Code 28 composition is slightly different than compositions of codes 29 and 30 specimens.

TABLE 16a. Statistical data for the

\begin{tabular}{|c|c|c|c|c|c|c|}
\hline \multirow{3}{*}{ Code } & \multirow{3}{*}{ Compared groups } & \multirow{3}{*}{$\begin{array}{c}\text { Critical } \\
\text { value }\end{array}$} & \multicolumn{4}{|c|}{$F$ and $t$ values for } \\
\hline & & & \multirow{2}{*}{$\underset{\text { density }}{\text { Bulk }}$} & \multirow{2}{*}{$\begin{array}{l}\text { Speed of } \\
\text { sound }\end{array}$} & \multicolumn{2}{|c|}{ Young's modulus } \\
\hline & & & & & $E_{l}$ & $E_{f w}$ \\
\hline \multirow[t]{2}{*}{30} & $\begin{array}{l}F \text {-test: } \\
\text { I and II }\end{array}$ & 4.03 & 1. 23 & 2.56 & 1.95 & 1.70 \\
\hline & I and II & 2. 10 & 1.43 & $\underline{2.59}$ & $\underline{2.25}$ & 1.80 \\
\hline \multirow[t]{2}{*}{28} & $\begin{array}{l}F \text {-test: } \\
\text { I and II }\end{array}$ & 4.03 & 40.8 & $\underline{14.9}$ & $\underline{18.3}$ & $\underline{7.67}$ \\
\hline & I and II & 2.10 & & & & \\
\hline
\end{tabular}

a Underlined figures indicate that a significant difference does exist between the compared groups. 
for $\mathrm{Al}_{2} \mathrm{O}_{3}+\mathrm{Cr}$

\begin{tabular}{|c|c|c|c|c|c|}
\hline Young's modulus-Con. & Shear modulus & \multicolumn{2}{|c|}{ Poisson's ratio } & \multicolumn{2}{|c|}{ Bulk modulus } \\
\hline$E_{\text {f。 }}$ & $G$ & $\mu l$ & $\mu \rho_{\omega}$ & $K_{1}$ & $K_{f w}$ \\
\hline $\begin{array}{l}2694 \pm 23 \text { kilobars } \\
\left(39.07 \pm 0.33 \times 10^{8} \mathrm{psi}\right) \\
1.8 \%\end{array}$ & $\begin{array}{l}107 . \pm \pm 8 \text { kilobars } \\
\left(15.58 \pm 0.12 \times 10^{5} \mathrm{psi}\right) \\
1.5 \%\end{array}$ & $\begin{array}{l}0.253 \pm 0.003 \\
2.3 \%\end{array}$ & $\begin{array}{l}0.262 \pm 0.001 \\
0.9 \%\end{array}$ & $\begin{array}{l}1813 \pm 35 \text { kilobars } \\
\left(26.30 \pm 0.51 \times 10^{6} \mathrm{psi}\right) \\
4.0 \%\end{array}$ & $\begin{array}{l}1900 \pm 14 \text { kilobars } \\
\left(27.56 \pm 0.20 \times 10^{8} \mathrm{psi}\right) \\
1.5 \%\end{array}$ \\
\hline $\begin{array}{l}2602 \div 28 \text { kilobars } \\
\left(37.7 \pm 0.41 \times 10^{8} \mathrm{psi}\right) \\
1.5 \%\end{array}$ & $\begin{array}{l}1032 \pm 8 \text { kilobars } \\
\left(14.97 \pm 0.12 \times 10^{6} \mathrm{psi}\right) \\
1.0 \%\end{array}$ & $\begin{array}{l}0.252 \pm 0.003 \\
1.5 \%\end{array}$ & $\begin{array}{l}0.264 \pm 0.003 \\
1.5 \%\end{array}$ & $\begin{array}{l}1732 \pm 22 \text { kilobars } \\
\left(25.12 \pm 0.32 \times 10^{6} \mathrm{psi}\right) \\
1.8 \%\end{array}$ & $\begin{array}{l}1845 \pm 29 \text { kilobars } \\
\left(26.76 \pm 0.42 \times 10^{6} \mathrm{psi}\right) \\
2.2 \%\end{array}$ \\
\hline $\begin{array}{l}2578 \pm 17 \text { kilobars } \\
\left(37.39 \pm 0.25 \times 10^{8} \mathrm{psi}\right) \\
0.9 \%\end{array}$ & $\begin{array}{l}1023 \pm 6 \text { kilobars } \\
\left(14.84 \pm 0.09 \times 10^{6} \mathrm{psi}\right) \\
0.8 \%\end{array}$ & $\begin{array}{l}0.252 \pm 0.001 \\
0.6 \%\end{array}$ & $\begin{array}{l}0.266 \pm 0.002 \\
1.2 \%\end{array}$ & $\begin{array}{l}1724 \pm 9 \text { kilobars } \\
\left(25.00 \pm 0.13 \times 10^{8} \mathrm{psi}\right) \\
0.8 \%\end{array}$ & $\begin{array}{l}1848 \pm 22 \text { kilobars } \\
\left(26.80 \pm 0.32 \times 10^{6} \mathrm{psi}\right) \\
1.7 \%\end{array}$ \\
\hline $\begin{array}{l}2682 \pm 20 \text { kilobars } \\
\left(38.90 \pm 0.29 \times 10^{\circ} \mathrm{psi}\right) \\
1.0 \%\end{array}$ & $\begin{array}{l}1114 \pm 6 \text { kilobars } \\
\left(16.16 \pm 0.09 \times 10^{6} \mathrm{psi}\right) \\
0.8 \%\end{array}$ & $\begin{array}{l}0.205 \pm 0.001 \\
1.0 \%\end{array}$ & $\begin{array}{l}0.217 \pm 0.004 \\
2.2 \%\end{array}$ & $\begin{array}{l}1512 \pm 8 \text { kilobars } \\
\left(21.93 \pm 0.12 \times 10^{6} \mathrm{psi}\right) \\
0.8 \%\end{array}$ & $\begin{array}{l}1601 \pm 30 \text { kilobars } \\
\left(23.22 \pm 0.44 \times 10^{\circ} \mathrm{psi}\right) \\
2.7 \%\end{array}$ \\
\hline $\begin{array}{l}2514 \pm 56 \text { kilobars } \\
\left(36.46 \pm 0.81 \times 10^{\circ} \mathrm{psi}\right) \\
3.2 \%\end{array}$ & $\begin{array}{l}1042 \pm 27 \text { kilobars } \\
\left(15.11 \pm 0.39 \times 10^{6} \mathrm{psi}\right) \\
3.0 \%\end{array}$ & $\begin{array}{l}0.203 \pm 0.001 \\
0.8 \%\end{array}$ & $\begin{array}{l}0.221 \pm 0.004 \\
2.6 \%\end{array}$ & $\begin{array}{l}1434 \pm 29 \text { kilobars } \\
\left(20.80 \pm 0.42 \times 10^{6} \mathrm{psi}\right) \\
2.8 \%\end{array}$ & $\begin{array}{l}1517 \pm 39 \text { kilobars } \\
\left(22.00 \pm 0.57 \times 10^{8} \mathrm{psi}\right) \\
3.6 \%\end{array}$ \\
\hline
\end{tabular}

analysis of values given in table 16

\begin{tabular}{|c|c|c|c|c|c|}
\hline \multicolumn{6}{|c|}{$F$ and $t$ ralnes for-Continued } \\
\hline $\begin{array}{l}\text { Young's } \\
\text { modulus- }\end{array}$ & $\begin{array}{c}\text { Shear } \\
\text { modulus }\end{array}$ & \multicolumn{2}{|c|}{ Poisson's ratio } & \multicolumn{2}{|c|}{ Bulk modulus } \\
\hline$E_{\text {f。 }}$ & $G$ & $\mu_{l}$ & $\mu_{f w}$ & $K_{l}$ & $K_{f w}$ \\
\hline 1. 75 & 1.90 & 5.74 & 1.62 & 5.48 & 1.77 \\
\hline 1.94 & 2.27 & .....- & 0.15 & & 0.20 \\
\hline$\underline{8.45}$ & $\underline{13.8}$ & 1.34 & 1.39 & $\underline{12.3}$ & 1.65 \\
\hline- & . & $\underline{2.16}$ & 1.33 & & $\underline{3.83}$ \\
\hline
\end{tabular}


TABLE 17. Data for TiC

\begin{tabular}{|c|c|c|c|c|c|c|c|}
\hline \multirow{2}{*}{$\begin{array}{l}\text { Code } \\
\text { and } \\
\text { group }\end{array}$} & \multirow{2}{*}{ Source } & \multirow{2}{*}{$\begin{array}{l}\text { Statistical } \\
\text { parameters }\end{array}$} & \multirow{2}{*}{$\begin{array}{l}\text { No. of } \\
\text { speci- } \\
\text { mens }\end{array}$} & \multirow{2}{*}{ Bulk density } & \multirow{2}{*}{ Speed of sound } & \multicolumn{2}{|c|}{ Young's modulus } \\
\hline & & & & & & $E_{l}$ & $E_{f w}$ \\
\hline $31-\mathrm{I}$ & $\mathrm{E}$ & $\begin{array}{c}\text { Average } \\
\qquad\end{array}$ & 10 & $\begin{array}{l}5.341 \pm 0.012 \mathrm{~g} / \mathrm{cm}^{3} \\
\left(333.4 \pm 0.7 \mathrm{lb} / \mathrm{ft}^{3}\right) \\
0.3 \%\end{array}$ & $\begin{array}{l}8576 \pm 23 \mathrm{~m} / \mathrm{sec} \\
\left(28.14 \pm 0.08 \times 10^{3} \mathrm{ft} / \mathrm{sec}\right) \\
0.4 \%\end{array}$ & $\begin{array}{l}3928 \pm 29 \text { kilobars } \\
\left(56.97 \pm 0.42 \times 10^{6} \mathrm{psi}\right) \\
1.0 \%\end{array}$ & $\begin{array}{l}4035 \pm 30 \text { kilobars } \\
\left(58.52 \pm 0.44 \times 10^{6} \mathrm{psi}\right) \\
1.0 \%\end{array}$ \\
\hline $31-$ II & & $\begin{array}{c}\text { A verage } \\
\mathrm{V}\end{array}$ & 10 & $\begin{array}{l}5.343 \pm 0.008 \mathrm{~g} / \mathrm{cm}^{3} \\
\left(333.6 \pm 0.5 \mathrm{lb} / \mathrm{ft}^{3}\right) \\
0.2 \%\end{array}$ & $\begin{array}{l}8549 \pm 15 \mathrm{~m} / \mathrm{sec} \\
\left(28.05 \pm 0.05 \times 10^{3} \mathrm{ft} / \mathrm{sec}\right) \\
0.3 \%\end{array}$ & $\begin{array}{l}3905 \pm 19 \text { kilobars } \\
\left(56.64 \pm 0.28 \times 10^{6} \mathrm{psi}\right) \\
0.7 \%\end{array}$ & $\begin{array}{l}3996 \pm 16 \text { kilobars } \\
\left(57.96 \pm 0.23 \times 10^{8} \text { psi }\right) \\
0.6 \%\end{array}$ \\
\hline $32-\mathrm{I}$ & $\mathrm{E}$ & $\begin{array}{c}\text { Average } \\
\mathrm{V}\end{array}$ & 10 & $\begin{array}{l}5.654 \pm 0.003 \mathrm{~g} / \mathrm{cm}^{3} \\
\left(353.0 \pm 0.2 \mathrm{lb} / \mathrm{ft}^{3}\right) \\
0.1 \%\end{array}$ & $\begin{array}{l}8467 \pm 8 \mathrm{~m} / \mathrm{sec} \\
\left(27.78 \pm 0.03 \times 10^{3} \mathrm{ft} / \mathrm{sec}\right) \\
0.1 \%\end{array}$ & $\begin{array}{l}4053 \pm 8 \text { kilobars } \\
\left(58.78 \pm 0.12 \times 10^{6} \mathrm{psi}\right) \\
0.3 \%\end{array}$ & $\begin{array}{l}4086 \pm 9 \text { kilobars } \\
\left(59.26 \pm 0.13 \times 10^{6} \mathrm{psi}\right) \\
0.3 \%\end{array}$ \\
\hline $32-\mathrm{II}$ & . & $\begin{array}{c}\text { A rerage } \\
\qquad\end{array}$ & 10 & $\begin{array}{l}5.541 \pm 0.004 \mathrm{~g} / \mathrm{cm}^{3} \\
\left(345.9 \pm 0.2 \mathrm{lb} / \mathrm{ft}^{3}\right) \\
0.1 \%\end{array}$ & $\begin{array}{l}8249 \pm 9 \mathrm{~m} / \mathrm{sec} \\
\left(27.06 \pm 0.03 \times 10^{3} \mathrm{ft} / \mathrm{sec}\right) \\
0.2 \%\end{array}$ & $\begin{array}{l}3770 \pm 9 \text { kilobars } \\
\left(54.68 \pm 0.13 \times 10^{6} \mathrm{psi}\right) \\
0.3 \%\end{array}$ & $\begin{array}{l}3866 \pm 15 \text { kilobars } \\
\left(56.07 \pm 0.22 \times 10^{6} \mathrm{psi}\right) \\
0.5 \%\end{array}$ \\
\hline $33-\mathrm{I}$ & $\mathrm{E}$ & $\begin{array}{c}\text { Average } \\
\text { V }\end{array}$ & 10 & $\begin{array}{l}5.862 \pm 0.002 \mathrm{~g} / \mathrm{cm}^{3} \\
\left(366.0 \pm 0.1 \mathrm{lb} / \mathrm{ft}^{3}\right) \\
0.0 \%\end{array}$ & $\begin{array}{l}8023 \pm 5 \mathrm{~m} / \mathrm{sec} \\
\left(26.32 \pm 0.02 \times 10^{3} \mathrm{ft} / \mathrm{sec}\right) \\
0.1 \%\end{array}$ & $\begin{array}{l}3773 \pm 5 \text { kilobars } \\
\left(54.72 \pm 0.07 \times 10^{6} \mathrm{psi}\right) \\
0.2 \%\end{array}$ & $\begin{array}{l}3808 \pm 7 \text { kilobars } \\
\left(55.23 \pm 0.10 \times 10^{6} \mathrm{psi}\right) \\
0.3 \%\end{array}$ \\
\hline $33-\mathrm{II}$ & & $\begin{array}{l}\text { Average } \\
\mathrm{V}\end{array}$ & 10 & $\begin{array}{l}5.821 \pm 0.005 \mathrm{~g} / \mathrm{cm}^{3} \\
\left(363.4 \pm 0.3 \mathrm{lb} / \mathrm{ft}^{3}\right) \\
0.1 \%\end{array}$ & $\begin{array}{l}7998 \pm 9 \mathrm{~m} / \mathrm{sec} \\
\left(26.24 \pm 0.03 \times 10^{3} \mathrm{ft} / \mathrm{sec}\right) \\
0.2 \%\end{array}$ & $\begin{array}{l}3749 \pm 9 \text { kilobars } \\
\left(54.37 \pm 0.13 \times 10^{6} \mathrm{psi}\right) \\
0.3 \%\end{array}$ & $\begin{array}{l}3757 \pm 12 \text { kilobars } \\
\left(54.49 \pm 0.17 \times 10^{6} \mathrm{psi}\right) \\
0.5 \%\end{array}$ \\
\hline $34-\mathrm{I}$ & $\mathrm{E}$ & $\begin{array}{c}\text { Average } \\
\mathrm{V}\end{array}$ & 10 & $\begin{array}{l}5.723 \pm 0.003 \mathrm{~g} / \mathrm{cm}^{3} \\
\left(357.3 \pm 0.2 \mathrm{lb} / \mathrm{ft}^{3}\right) \\
0.1 \%\end{array}$ & $\begin{array}{l}8267 \pm 7 \mathrm{~m} / \mathrm{sec} \\
\left(27.12 \pm 0.02 \times 10^{3} \mathrm{ft} / \mathrm{sec}\right) \\
0.1 \%\end{array}$ & $\begin{array}{l}3911 \pm 7 \text { kilobars } \\
\left(56.72 \pm 0.10 \times 10^{6} \mathrm{psi}\right) \\
0.3 \%\end{array}$ & $\begin{array}{l}3917 \pm 11 \text { kilobars } \\
\left(56.81 \pm 0.16 \times 10^{6} \mathrm{psi}\right) \\
0.4 \%\end{array}$ \\
\hline $34-\mathrm{II}$ & & $\begin{array}{c}\text { Average } \\
\mathrm{V}\end{array}$ & 10 & $\begin{array}{l}5.882 \pm 0.006 \mathrm{~g} / \mathrm{cm}^{3} \\
\left(367.2 \pm 0.4 \mathrm{bb} / \mathrm{ft}^{3}\right) \\
0.1 \%\end{array}$ & $\begin{array}{l}8056 \pm 5 \mathrm{~m} / \mathrm{sec} \\
\left(26.43 \pm 0.02 \times 10^{3} \mathrm{ft} / \mathrm{sec}\right) \\
0.1 \%\end{array}$ & $\begin{array}{l}3817 \pm 6 \text { kilobars } \\
\left(55.36 \pm 0.09 \times 10^{6} \mathrm{psi}\right) \\
0.2 \%\end{array}$ & $\begin{array}{l}3904 \pm 9 \text { kilobars } \\
\left(56.62 \pm 0.13 \times 10^{6} \text { psi }\right) \\
0.3 \%\end{array}$ \\
\hline
\end{tabular}

a Code 31 contains about $10 \mathrm{wt} \% \mathrm{Ni}$. Code 32 contains about $20 \mathrm{wt} \% \mathrm{Ni}$. Code 33 contains about $30 \mathrm{wt} \%$ Ni. Code 34 contains about $30 \mathrm{wt} \% \mathrm{Ni}$ (Modified).

TABLE 17a. Statistical data for the

\begin{tabular}{|c|c|c|c|c|c|c|}
\hline \multirow{3}{*}{ Code } & \multirow{3}{*}{ Compared groups } & \multirow{3}{*}{$\begin{array}{c}\text { Critical } \\
\text { value }\end{array}$} & \multicolumn{4}{|c|}{$F$ and $t$ values for } \\
\hline & & & \multirow{2}{*}{$\begin{array}{l}\text { Bulk } \\
\text { density }\end{array}$} & \multirow{2}{*}{$\begin{array}{l}\text { Speed of } \\
\text { sound }\end{array}$} & \multicolumn{2}{|c|}{ Young's modulus } \\
\hline & & & & & $E_{l}$ & $E_{f \omega}$ \\
\hline \multirow[t]{2}{*}{31} & $F$-test: & 4.03 & 1.94 & 2. 25 & 2. 35 & 3.48 \\
\hline & I and II & 2. 10 & 0.30 & 2.22 & 1.53 & $\underline{2.60}$ \\
\hline \multirow[t]{2}{*}{32} & $F$-test: & 4. 03 & 1.71 & 1.15 & 1.22 & 2.53 \\
\hline & I and II & 2.10 & a 4 7.2 & $\underline{41.2}$ & 52.4 & 28.1 \\
\hline \multirow[t]{2}{*}{33} & $F$-test: & 4.03 & 6.11 & 3.72 & 2. 78 & 3.29 \\
\hline & I and II & 2. 10 & - & $\underline{49.7}$ & $\underline{5.47}$ & $\underline{8.31}$ \\
\hline \multirow[t]{2}{*}{34} & $F$-test: & 4. 03 & 5. 14 & 2.20 & 1. 50 & 1.58 \\
\hline & I and II & 2.10 & & 56.5 & $\underline{24.0}$ & $\underline{2.20}$ \\
\hline
\end{tabular}

a Underlined figures indicate that a significant difference does cxist between the compared groups.

TABLE 18. Dato

\begin{tabular}{|c|c|c|c|c|c|c|c|}
\hline \multirow{2}{*}{$\begin{array}{l}\text { Code } \\
\text { azd } \\
\text { group }\end{array}$} & \multirow{2}{*}{ Souree } & \multirow{2}{*}{$\begin{array}{l}\text { Statistical } \\
\text { parameters }\end{array}$} & \multirow{2}{*}{$\begin{array}{l}\text { No. of } \\
\text { speci- } \\
\text { mens }\end{array}$} & \multirow{2}{*}{ Bulk density } & \multirow{2}{*}{ Speed of sound } & \multicolumn{2}{|c|}{ Young's modulus } \\
\hline & & & & & & $E_{l}$ & $E_{f w}$ \\
\hline $44-\mathrm{I}$ & $\mathrm{HI}$ & $\begin{array}{c}\text { Average } \\
\mathrm{V}\end{array}$ & 10 & $\begin{array}{l}2.506 \pm 0.002 \mathrm{~g} / \mathrm{cm}^{3} \\
\left(156.4 \pm 0.1 \mathrm{lb} / \mathrm{ft}^{3}\right) \\
0.1 \%\end{array}$ & & & $\begin{array}{l}4467 \pm 24 \text { kilobars } \\
\left(64.79 \pm 0.35 \times 10^{6} \mathrm{psi}\right) \\
0.7 \%\end{array}$ \\
\hline 44-II & & $\begin{array}{c}\text { Average } \\
\mathrm{V}\end{array}$ & 10 & $\begin{array}{l}2.505 \pm 0.002 \mathrm{~g} / \mathrm{cm}^{3} \\
\left(156.4 \pm 0.1 \mathrm{lb} / \mathrm{ft}^{3}\right) \\
0.1 \%\end{array}$ & & & $\begin{array}{l}4481 \pm 19 \text { kilobars } \\
\left(64.99 \pm 0.28 \times 10^{8} \mathrm{psi}\right) \\
0.6 \%\end{array}$ \\
\hline
\end{tabular}

a These values are not considered reliable because of an assumption that was made during the calculation.

$\mathrm{b}_{\mu}=0.2074$ assumed value for one specimen see sec. $2.3(\mathrm{a})$. 


\begin{tabular}{|c|c|c|c|c|c|}
\hline Young's modulus-Con. & Shear modulus & \multicolumn{2}{|c|}{ Poisson's ratio } & \multicolumn{2}{|c|}{ Bulk modulus } \\
\hline$E_{\text {fe }}$ & $G$ & $\mu 1$ & $\mu / t$ & $K_{l}$ & $K_{f v}$ \\
\hline $\begin{array}{l}4027 \pm 29 \text { kilobars } \\
\left.58.41 \pm 0.42 \times 10^{3} \mathrm{psi}\right) \\
1.0 \%\end{array}$ & $\begin{array}{l}1654 \pm 11 \text { kilobars } \\
\left(23.99 \pm 0.16 \times 10^{6} \mathrm{psi}\right) \\
0.9 \%\end{array}$ & $\begin{array}{l}0.1 \times 5 \pm 0.003 \\
2.1 \%\end{array}$ & $\begin{array}{l}0.220 \pm 0.003 \\
2.1 \%\end{array}$ & $\begin{array}{l}2099 \pm 25 \text { kilobars } \\
\left(30.44 \pm 0.36 \times 10^{6} \mathrm{psi}\right) \\
1.7 \%\end{array}$ & $\begin{array}{l}2403 \pm 29 \text { kilobars } \\
\left(34.85 \pm 0.42 \times 10^{6} \mathrm{psi}\right) \\
1.7 \%\end{array}$ \\
\hline $\begin{array}{l}4031 \pm 15 \text { Kilobars } \\
\left(58.46 \pm 0.22 \times 10^{5} \mathrm{psi}\right) \\
0.5 \%\end{array}$ & $\begin{array}{l}1631 \pm 8 \text { kilobars } \\
\left(23.66 \pm 0.12 \times 10^{3} \text { psi }\right) \\
0.6 \%\end{array}$ & $\begin{array}{l}0.197 \pm 0.003 \\
1.9 \%\end{array}$ & $\begin{array}{l}0.225 \pm 0.002 \\
1.5 \%\end{array}$ & $\begin{array}{l}2149 \pm 18 \text { kilobars } \\
\left(31.17 \pm 0.26 \times 10^{6} \text { psi) }\right. \\
1.2 \%\end{array}$ & $\begin{array}{l}2427 \pm 11 \text { kilobars } \\
\left(35.20 \pm 0.16 \times 10^{6} \mathrm{psi}\right) \\
0.7 \%\end{array}$ \\
\hline $\begin{array}{l}4081 \pm 8 \text { kilobars } \\
\left(59.19 \pm 0.12 \times 10^{8} \mathrm{psi}\right) \\
0.3 \%\end{array}$ & $\begin{array}{l}1681 \pm 3 \text { kilobars } \\
\left(24.38 \pm 0.04 \times 10^{5} \mathrm{psi}\right) \\
0.2 \%\end{array}$ & $\begin{array}{l}0.206 \pm 0.003 \\
2.0 \%\end{array}$ & $\begin{array}{l}0.216 \pm 0.003 \\
2.0 \%\end{array}$ & $\begin{array}{l}2295 \pm 23 \text { kilobars } \\
\left(33.29 \pm 0.33 \times 10^{6} \text { psi) }\right. \\
1.4 \%\end{array}$ & $\begin{array}{l}2394 \pm 4 \text { kilobars } \\
\left(31.72 \pm 0.06 \times 10^{6} \mathrm{psi}\right) \\
0.2 \%\end{array}$ \\
\hline $\begin{array}{l}3851 \pm 10 \text { kilobars } \\
\left(55.85 \pm 0.15 \times 10^{8} \mathrm{psi}\right) \\
0.4 \%\end{array}$ & $\begin{array}{l}1548 \pm 6 \text { kilobars } \\
\left(22.45 \pm 0.09 \times 10^{6} \mathrm{psi}\right) \\
0.5 \%\end{array}$ & $\begin{array}{l}0.197 \pm 0.00 t \\
3.0 \%\end{array}$ & $\begin{array}{l}0.228 \pm 0.005 \\
3.4 \%\end{array}$ & $\begin{array}{l}2078 \pm 30 \text { kilobars } \\
\left(30.14 \pm 0.44 \times 10^{6} \mathrm{psi}\right) \\
2.0 \%\end{array}$ & $\begin{array}{l}2368 \pm 42 \text { kilobars } \\
\left(34.34 \pm 0.61 \times 10^{6} \text { psi) }\right. \\
2.5 \%\end{array}$ \\
\hline $\begin{array}{l}3804 \pm 8 \text { kilobars } \\
\left(55.17 \pm 0.12 \times 10^{6} \text { psi }\right) \\
0.3 \%\end{array}$ & $\begin{array}{l}1560 \pm 6 \text { kilobars } \\
\left(22.63 \pm 0.09 \times 10^{3} \mathrm{psi}\right) \\
0.5 \%\end{array}$ & $\begin{array}{l}0.210 \pm 0.001 \\
0.9 \%\end{array}$ & $\begin{array}{l}0.221 \pm 0.002 \\
1.1 \%\end{array}$ & $\begin{array}{l}2168 \pm 5 \text { hilobars } \\
\left(31.41 \pm 0.07 \times 10^{6} \mathrm{psi}\right) \\
0.3 \%\end{array}$ & $\begin{array}{l}227 \tilde{5} \pm 5 \text { hilobars } \\
\left(33.00 \pm 0.07 \times 10^{6} \mathrm{psi}\right) \\
0.3 \%\end{array}$ \\
\hline $\begin{array}{l}3.41 \pm 13 \text { kilobars } \\
\left(54.26 \pm 0.19 \times 10^{6} \text { psi }\right) \\
0.5 \%\end{array}$ & $\begin{array}{l}1538 \pm 6 \text { kilobars } \\
\left(22.31 \pm 0.09 \times 10^{8} \text { psi }\right) \\
0.5 \%\end{array}$ & $\begin{array}{l}0.219 \pm 0.003 \\
1.8 \%\end{array}$ & $\begin{array}{l}0.222 \pm 0.002 \\
1.4 \%\end{array}$ & $\begin{array}{l}2226 \pm 13 \text { kilobars } \\
\left(32.29 \pm 0.19 \times 10^{5} \mathrm{psi}\right) \\
0.8 \%\end{array}$ & $\begin{array}{l}2249 \pm 15 \text { kilobars } \\
\left(32.62 \pm 0.22 \times 10^{\circ} \mathrm{psi}\right) \\
0.9 \%\end{array}$ \\
\hline- & $\begin{array}{l}1699 \pm 3 \text { kilobars } \\
\left(24.64 \pm 0.04 \times 10^{8} \text { psi }\right) \\
0.3 \%\end{array}$ & $\begin{array}{l}0.151 \pm 0.003 \\
2.7 \%\end{array}$ & $\begin{array}{l}0.153 \pm 0.004 \\
3.5 \%\end{array}$ & $\begin{array}{l}1871 \pm 16 \text { kilobars } \\
\left(27.14 \pm 0.23 \times 10^{6} \text { psi }\right) \\
1.2 \%\end{array}$ & $\begin{array}{l}1882 \pm 24 \text { kilobars } \\
\left(27.30 \pm 0.35 \times 10^{6} \mathrm{psi}\right) \\
1.8 \%\end{array}$ \\
\hline $\begin{array}{l}3536 \pm 9 \text { kilobars } \\
\left(56.36 \pm 0.13 \times 10^{-3} \text { psi }\right) \\
0.3 \%\end{array}$ & $\begin{array}{l}1586 \pm 2 \text { kilobars } \\
\left(23.00 \pm 0.03 \times 10^{8} \mathrm{psi}\right) \\
0.2 \%\end{array}$ & $\begin{array}{l}0.204 \pm 0.002 \\
1.2 \%\end{array}$ & $\begin{array}{l}0.231 \pm 0.003 \\
1.7 \%\end{array}$ & $\begin{array}{l}2147 \pm 3 \text { kilobars } \\
\left(31.14 \pm 0.04 \times 10^{6} \text { psi) }\right. \\
0.2 \%\end{array}$ & $\begin{array}{l}2417 \pm 28 \text { kilobars } \\
\left(35.06 \pm 0.41 \times 10^{6} \mathrm{psi}\right) \\
1.6 \%\end{array}$ \\
\hline
\end{tabular}

analysis of values given in table 17

\begin{tabular}{|c|c|c|c|c|c|}
\hline \multicolumn{6}{|c|}{$F$ and $t$ ralues for-Continued } \\
\hline $\begin{array}{l}\text { Young's } \\
\text { modulus }\end{array}$ & $\begin{array}{l}\text { Shear } \\
\text { modulus }\end{array}$ & \multicolumn{2}{|c|}{ Poisson's ratio } & \multicolumn{2}{|c|}{ Bulk modulus } \\
\hline$E_{f 0}$ & $G$ & $u_{l}$ & $\mu \int t$ & $K_{l}$ & $K_{f \infty}$ \\
\hline 3.62 & 2. 00 & 1. 18 & 1.69 & 2.06 & 6.73 \\
\hline 0.24 & $\underline{3.98}$ & $\underline{5.55}$ & $\underline{2.89}$ & $\underline{3.75}$ & -..- \\
\hline 1. 46 & 5.60 & 1.98 & 3.08 & 1.62 & 1.98 \\
\hline 40.8 & -.... & $\underline{3.64}$ & $\underline{4.31}$ & $\underline{13.1}$ & 1.41 \\
\hline 2.65 & 1. 07 & 4. 22 & 1. 76 & 7.79 & 9.57 \\
\hline 9. 75 & $\underline{5.84}$ & & 0.68 & & \\
\hline & 1.78 & 2.85 & 1.81 & 3.06 & 1.38 \\
\hline & 64.8 & $\underline{35.3}$ & $\underline{36.8}$ & $\underline{38.3}$ & 32.7 \\
\hline
\end{tabular}

for $\mathrm{B}_{4} \mathrm{C}$

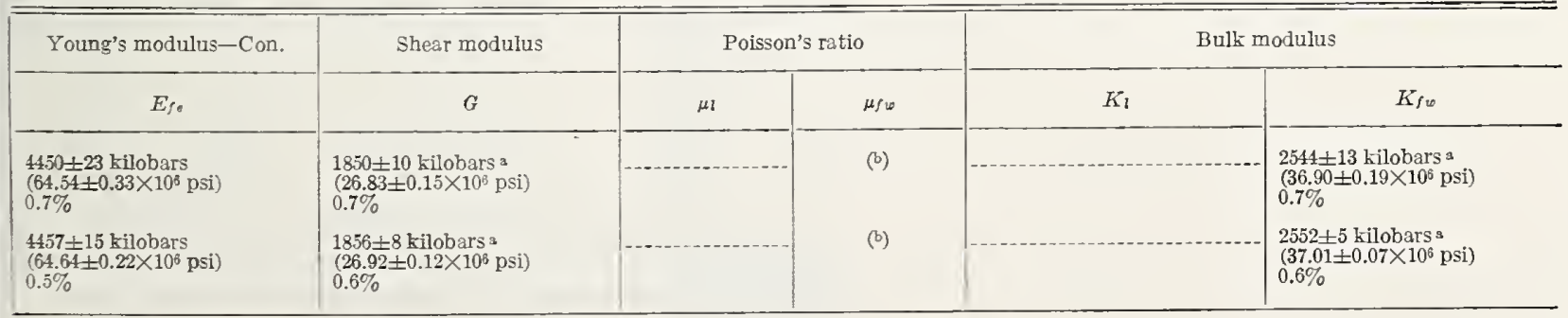


TABle 19. Data

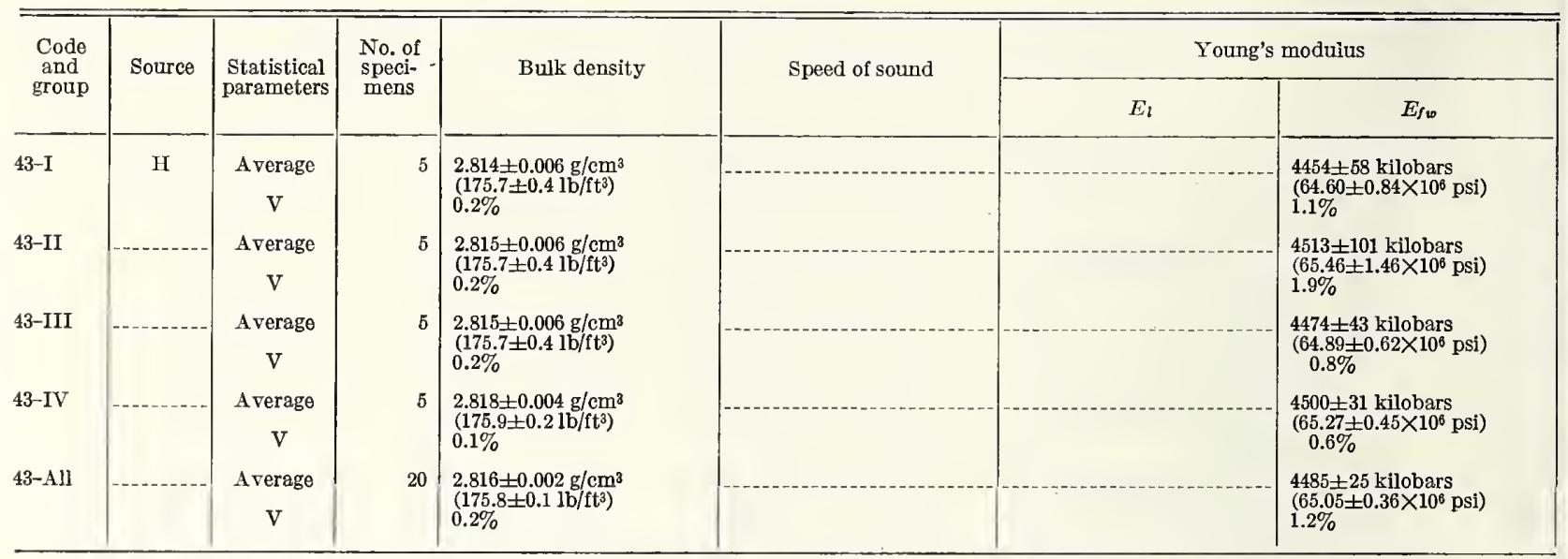

$\therefore$ This mixture contains 82 parts (volume) of $\mathrm{B}_{4} \mathrm{C}$ and 18 parts $\mathrm{TiB}_{2}$

- These values are not considered reliable because of an assumption that was made during the calculation.

${ }^{\circ} \mu=0.2056$ assumed value for one specimen, see sec. 2.3(a).

TABLE 20.

\begin{tabular}{|c|c|c|c|c|c|c|c|}
\hline \multirow{2}{*}{$\begin{array}{l}\text { Code } \\
\text { and } \\
\text { group }\end{array}$} & \multirow{2}{*}{ Source } & \multirow{2}{*}{$\begin{array}{l}\text { Statistical } \\
\text { parameters }\end{array}$} & \multirow{2}{*}{$\begin{array}{l}\text { No. of } \\
\text { speci- } \\
\text { mens }\end{array}$} & \multirow{2}{*}{ Bulk density } & \multirow{2}{*}{ Speed of sound } & \multicolumn{2}{|c|}{ Young's modulus } \\
\hline & & & & & & $E_{l}$ & $E_{f w}$ \\
\hline $45-\mathrm{I}$ & B & $\begin{array}{c}\text { Average } \\
\text { V } \\
\text { Average } \\
\text { V }\end{array}$ & 9 & $\begin{array}{l}3.103 \pm 0.012 \mathrm{gm} / \mathrm{cm}^{3} \\
\left(193.7 \pm 0.7 \mathrm{lb} / \mathrm{ft}^{3}\right) \\
0.5 \% \\
3.128 \pm 0.002 \mathrm{gm} / \mathrm{cm}^{3} \\
\left(195.3 \pm 0.1 \mathrm{lb} / \mathrm{ft}^{3}\right) \\
0.1 \%\end{array}$ & & & $\begin{array}{l}3,948 \pm 64 \text { kilobars } \\
\left(57.26 \pm 0.93 \times 10^{6} \mathrm{psi}\right) \\
2.1 \% \\
4,013 \pm 15 \text { kilobars } \\
\left(58.20 \pm 0.22 \times 10^{6} \mathrm{psi}\right) \\
0.4 \%\end{array}$ \\
\hline $35-\mathrm{I}$ & $\mathrm{H}$ & $\begin{array}{c}\text { Average } \\
\text { V } \\
\text { Average } \\
\text { V }\end{array}$ & 10 & $\begin{array}{l}2.576 \pm 0.004 \mathrm{gm} / \mathrm{cm}^{3} \\
\left(160.8 \pm 0.2 \mathrm{lb} / \mathrm{ft}^{3}\right) \\
0.2 \% \\
2.596 \pm 0.005 \mathrm{gm} / \mathrm{cm}^{3} \\
\left(162.1 \pm 0.3 \mathrm{lb} / \mathrm{ft}^{3}\right) \\
0.2 \%\end{array}$ & $\begin{array}{l}8,818 \pm 87 \mathrm{~m} / \mathrm{sec} \\
\left(28.93 \pm 0.29 \times 10^{3} \mathrm{ft} / \mathrm{sec}\right) \\
1.4 \% \\
8,74 \pm \pm 1 \mathrm{~m} / \mathrm{sec} \\
\left(28.69 \pm 0.27 \times 10^{3} \mathrm{ft} / \mathrm{sec}\right) \\
1.2 \%\end{array}$ & $\begin{array}{l}2,003 \pm 41 \text { kilobars } \\
\left(29.05 \pm 0.59 \times 10^{6} \mathrm{psi}\right) \\
2.9 \% \\
1,985 \pm 39 \text { kilobars } \\
\left(28.79 \pm 0.57 \times 10^{6} \mathrm{psi}\right) \\
2.5 \%\end{array}$ & $\begin{array}{l}2,021 \pm 43 \text { kilobars } \\
\left(29.31 \pm 0.62 \times 10^{6} \mathrm{psi}\right) \\
3.0 \% \\
1,963 \pm 50 \text { kilobars } \\
\left(28.47 \pm 0.73 \times 10^{6} \mathrm{psi}\right) \\
3.3 \%\end{array}$ \\
\hline
\end{tabular}

TABLE 20a. Statistical data for the

\begin{tabular}{|c|c|c|c|c|c|c|}
\hline \multirow{3}{*}{ Code } & \multirow{3}{*}{ Compared groups } & \multirow{3}{*}{$\begin{array}{c}\text { Critical } \\
\text { value }\end{array}$} & \multicolumn{4}{|c|}{$F$ and $t$ values for } \\
\hline & & & \multirow{2}{*}{$\underset{\text { density }}{\text { Bulk }}$} & \multirow{2}{*}{$\begin{array}{l}\text { Speed of } \\
\text { sound }\end{array}$} & \multicolumn{2}{|c|}{ Young's modulus } \\
\hline & & & & & $E_{l}$ & $E_{f w}$ \\
\hline 45 & $\begin{array}{l}F \text {-test: } \\
\text { I and II } \\
t \text {-test: } \\
\quad \text { I and II }\end{array}$ & $\begin{array}{r}4.90- \\
\text { 8. } 53^{*} \\
2.13\end{array}$ & b 12.2 & & & $\underline{22.4} \underline{\underline{H}}^{*}$ \\
\hline 35 & $\begin{array}{l}F \text {-test: } \\
\text { I and II } \\
t \text {-test: } \\
\text { I and II }\end{array}$ & $\begin{array}{l}\text { 4. } 36- \\
4.10^{*} \\
2.11\end{array}$ & $\begin{array}{l}1.71^{*} \\
\underline{7.85} \\
\end{array}$ & $\begin{array}{l}1.34 \\
1.92\end{array}$ & $\begin{array}{l}1.33 \\
0.71\end{array}$ & $\begin{array}{l}1.15^{*} \\
2.03\end{array}$ \\
\hline
\end{tabular}

- $F$ and $t$ values marked with an asterisk indicate comparison with the critical value similarly marked.

b Underlined figures indicate that a significant difference does exist between the compared groups. 
TABLE 21. Data for

\begin{tabular}{|c|c|c|c|c|c|c|c|}
\hline \multirow{2}{*}{$\begin{array}{l}\text { Code } \\
\text { and } \\
\text { group }\end{array}$} & \multirow{2}{*}{ Source } & \multirow{2}{*}{$\begin{array}{l}\text { Statistical } \\
\text { parameters }\end{array}$} & \multirow{2}{*}{$\begin{array}{l}\text { No. of } \\
\text { speci- } \\
\text { mens }\end{array}$} & \multirow{2}{*}{ Bulk density } & \multirow{2}{*}{ Speed of sound } & \multicolumn{2}{|c|}{ Young's modulus } \\
\hline & & & & & & $E_{l}$ & $E_{f v}$ \\
\hline $37-\mathrm{I}$ & $\mathrm{H}$ & $\begin{array}{c}\text { A verage } \\
\text { V }\end{array}$ & 5 & $\begin{array}{l}3.074 \pm 0.007 \mathrm{~g} / \mathrm{cm}^{3} \\
\left(191.9 \pm 0.4 \mathrm{lb} / \mathrm{ft}^{3}\right) \\
0.2 \%\end{array}$ & & & $\begin{array}{l}4120 \pm 45 \text { kilobars } \\
\left(59.76 \pm 0.65 \times 10^{6} \mathrm{psi}\right) \\
0.9 \%\end{array}$ \\
\hline $37-\mathrm{II}$ & & $\begin{array}{c}\text { A verage } \\
\text { V }\end{array}$ & 5 & $\begin{array}{l}3.086 \pm 0.014 \mathrm{~g} / \mathrm{cm}^{3} \\
\left(192.7 \pm 0.9 \mathrm{lb} / \mathrm{ft}^{3}\right) \\
0.4 \%\end{array}$ & & & $\begin{array}{l}4114 \pm 37 \text { kilobars } \\
\left(59.67 \pm 0.54 \times 10^{6} \mathrm{psi}\right) \\
0.7 \%\end{array}$ \\
\hline $37-$ III & & $\begin{array}{c}\text { A verage } \\
\text { V }\end{array}$ & 5 & $\begin{array}{l}3.083 \pm 0.003 \mathrm{~g} / \mathrm{cm}^{3} \\
\left(192.5 \pm 0.2 \mathrm{lb} / \mathrm{ft}^{3}\right) \\
0.1 \%\end{array}$ & & & $\begin{array}{l}4121 \pm 72 \text { kilobars } \\
\left(59.77 \pm 1.04 \times 10^{6} \mathrm{psi}\right) \\
1.4 \%\end{array}$ \\
\hline $37-\mathrm{IV}$ & & $\begin{array}{c}\text { Average } \\
\text { V }\end{array}$ & 5 & $\begin{array}{l}3.084 \pm 0.006 \mathrm{~g} / \mathrm{cm}^{3} \\
\left(192.5 \pm 0.4 \mathrm{lb} / \mathrm{ft}^{3}\right) \\
0.2 \%\end{array}$ & & & $\begin{array}{l}4246 \pm 66 \text { kilobars } \\
\left(61.58 \pm 0.96 \times 10^{6} \mathrm{psi}\right) \\
1.3 \%\end{array}$ \\
\hline 37-All & & $\begin{array}{c}\text { Average } \\
\text { V }\end{array}$ & 20 & $\begin{array}{l}3.082 \pm 0.004 \mathrm{~g} / \mathrm{cm}^{3} \\
\left(192.4 \pm 0.2 \mathrm{lb} / \mathrm{ft}^{3}\right) \\
0.3 \%\end{array}$ & & & $\begin{array}{l}4151 \pm 31 \text { kilobars } \\
\left(60.21 \pm 0.45 \times 10^{8} \mathrm{psi}\right) \\
1.6 \%\end{array}$ \\
\hline
\end{tabular}

a This mixture contains 90 parts of $\mathrm{SiC}$ and 10 parts of $\mathrm{B}_{4} \mathrm{C}$ (by weight).

b These values are not considered reliable because of an assumption that was made during the calculation.

- $\mu=0.2208$ assumed value for one specimen, see sec. 2.3(a).

TABle 22. Data

\begin{tabular}{|c|c|c|c|c|c|c|c|}
\hline \multirow{2}{*}{$\begin{array}{l}\text { Code } \\
\text { and } \\
\text { group }\end{array}$} & \multirow{2}{*}{ Source } & \multirow{2}{*}{$\begin{array}{l}\text { Statistical } \\
\text { parameters }\end{array}$} & \multirow{2}{*}{$\begin{array}{l}\text { No. of } \\
\text { speci- } \\
\text { mens }\end{array}$} & \multirow{2}{*}{ Bulk density } & \multirow{2}{*}{ Speed of sound } & \multicolumn{2}{|c|}{ Young's modulus } \\
\hline & & & & & & $E_{l}$ & $E_{f w}$ \\
\hline $38-\mathrm{I}$ & $\mathrm{H}$ & Average & 1 & $\begin{array}{l}6.465 \mathrm{~g} / \mathrm{cm}^{3} \\
\left(403.6 \mathrm{lb} / \mathrm{ft}^{3}\right)\end{array}$ & & & $\begin{array}{l}3881 \text { kilobars } \\
\left(56.29 \times 10^{8} \mathrm{psi}\right)\end{array}$ \\
\hline 38-II & & $\begin{array}{c}\text { Average } \\
\mathrm{V}\end{array}$ & 2 & $\begin{array}{l}6.177 \pm 0.602 \mathrm{~g} / \mathrm{cm}^{3} \\
\left(385.6 \pm 37.6 \mathrm{bb} / \mathrm{ft}^{3}\right) \\
1.1 \%\end{array}$ & & & $\begin{array}{l}3045 \pm 515 \text { kilobars } \\
\left(44.16 \pm 7.47 \times 10^{6} \mathrm{psi}\right) \\
1.9 \%\end{array}$ \\
\hline 38-III & - & $\begin{array}{c}\text { A verage } \\
\text { V }\end{array}$ & 4 & $\begin{array}{l}6.148 \pm 0.028 \mathrm{~g} / \mathrm{cm}^{3} \\
\left(383.8 \pm 1.7 \mathrm{bb} / \mathrm{ft}^{3}\right) \\
0.3 \%\end{array}$ & & & $\begin{array}{l}3220 \pm 72 \text { kilobars } \\
\left(46.70 \pm 1.04 \times 10^{6} \mathrm{psi}\right) \\
1.4 \%\end{array}$ \\
\hline $38-\mathrm{IV}$ & & $\begin{array}{c}\text { Average } \\
\mathrm{V}\end{array}$ & 4 & $\begin{array}{l}6.202 \pm 0.009 \mathrm{~g} / \mathrm{cm}^{3} \\
\left(387.2 \pm 0.6 \mathrm{lb} / \mathrm{ft}^{3}\right) \\
0.1 \%\end{array}$ & & & $\begin{array}{l}3279 \pm 24 \text { kilobars } \\
\left(47.56 \pm 0.35 \times 10^{6} \mathrm{psi}\right) \\
0.5 \%\end{array}$ \\
\hline $38-\mathrm{V}$ & & $\begin{array}{c}\text { Average } \\
\text { V }\end{array}$ & 5 & $\begin{array}{l}6.016 \pm 0.031 \mathrm{~g} / \mathrm{cm}^{3} \\
\left(375.6 \pm 1.9 \mathrm{lb} / \mathrm{ft}^{3}\right) \\
0.4 \%\end{array}$ & & & $\begin{array}{l}2961 \pm 65 \text { kilobars } \\
\left(42.95 \pm 0.94 \times 10^{6} \mathrm{psi}\right) \\
1.8 \%\end{array}$ \\
\hline $38-\mathrm{VI}$ & & $\begin{array}{c}\text { Average } \\
\text { V }\end{array}$ & 4 & $\begin{array}{l}6.017 \pm 0.025 \mathrm{~g} / \mathrm{cm}^{3} \\
\left(375.6 \pm 1.6 \mathrm{bb} / \mathrm{ft}^{3}\right) \\
0.3 \%\end{array}$ & & & $\begin{array}{l}2890 \pm 89 \text { kilobars } \\
\left(41.92 \pm 1.29 \times 10^{6} \mathrm{psi}\right) \\
1.9 \%\end{array}$ \\
\hline 38-All & & $\begin{array}{c}\text { A verage } \\
\text { V }\end{array}$ & 20 & $\begin{array}{l}6.118 \pm 0.055 \mathrm{~g} / \mathrm{cm}^{3} \\
\left(381.9 \pm 3.4 \mathrm{lb} / \mathrm{ft}^{3}\right) \\
1.9 \%\end{array}$ & & & $\begin{array}{l}3117 \pm 113 \text { kilobars } \\
\left(45.21 \pm 1.64 \times 10^{6} \mathrm{psi}\right) \\
7.7 \%\end{array}$ \\
\hline
\end{tabular}


$\mathrm{SiC}+\mathrm{B}_{4} \mathrm{C}^{\mathrm{a}}$

\begin{tabular}{|c|c|c|c|c|c|}
\hline Young's modulus-Con. & Shear modulus & \multicolumn{2}{|c|}{ Poisson's ratio } & \multicolumn{2}{|c|}{ Bulk modulus } \\
\hline$E_{f \circ}$ & $G$ & $\mu t$ & $\mu_{f w}$ & $K_{l}$ & $K_{f \omega}$ \\
\hline $\begin{array}{l}4090 \pm 44 \text { kilobars } \\
\left(59.32 \pm 0.64 \times 10^{6} \mathrm{psi}\right) \\
0.9 \%\end{array}$ & $\begin{array}{l}1688 \pm 18 \text { kilobarsb } \\
\left(24.48 \pm 0.26 \times 10^{8} \mathrm{psi}\right) \\
0.9 \%\end{array}$ & & (०) & & $\begin{array}{l}2460 \pm 27 \text { kilobars b } \\
\left(35.68 \pm 0.39 \times 10^{6} \mathrm{psi}\right) \\
0.9 \%\end{array}$ \\
\hline $\begin{array}{l}4100 \pm 67 \text { kilobars } \\
\left(59.47 \pm 0.97 \times 10^{8} \mathrm{psi}\right) \\
1.3 \%\end{array}$ & $\begin{array}{l}1685 \pm 15 \text { kilobarsb } \\
\left(24.44 \pm 0.22 \times 10^{8} \mathrm{psi}\right) \\
0.7 \%\end{array}$ & & $(0)$ & & $\begin{array}{l}2456 \pm 22 \text { kilobars } \mathrm{b} \\
\left(35.62 \pm 0.32 \times 10^{6} \mathrm{psi}\right) \\
0.7 \%\end{array}$ \\
\hline $\begin{array}{l}4084 \pm 79 \text { kilobars } \\
\left(59.23 \pm 1.15 \times 10^{8} \mathrm{psi}\right) \\
1.6 \%\end{array}$ & $\begin{array}{l}1688 \pm 29 \text { kilobarsb } \\
\left(24.48 \pm 0.42 \times 10^{6} \mathrm{psi}\right) \\
1.4 \%\end{array}$ & & $(0)$ & & $\begin{array}{l}2460 \pm 43 \text { kilobars } \mathrm{b} \\
\left(35.68 \pm 0.62 \times 10^{8} \mathrm{psi}\right) \\
1.4 \%\end{array}$ \\
\hline $\begin{array}{l}4321 \pm 29 \text { kilobars } \\
\left(62.67 \pm 0.42 \times 10^{6} \mathrm{psi}\right) \\
0.6 \%\end{array}$ & $\begin{array}{l}1739 \pm 27 \text { kilobarsb } \\
\left(25.22 \pm 0.39 \times 10^{6} \mathrm{psl}\right) \\
1.3 \%\end{array}$ & & $(0)$ & & $\begin{array}{l}2535 \pm 40 \text { kilobars } \mathrm{b} \\
\left(36.77 \pm 0.58 \times 10^{6} \mathrm{psi}\right) \\
1.3 \%\end{array}$ \\
\hline $\begin{array}{l}4149 \pm 52 \text { kilobars } \\
\left(60.18 \pm 0.75 \times 10^{8} \mathrm{psi}\right) \\
2.7 \%\end{array}$ & $\begin{array}{l}1699 \pm 20 \text { kilobarsb } \\
\left(24.64 \pm 0.29 \times 10^{6} \mathrm{psi}\right) \\
1.6 \%\end{array}$ & & (c) & & $\begin{array}{l}2478 \pm 29 \text { kilobars }{ }^{b} \\
\left(35.94 \pm 0.42 \times 10^{6} \mathrm{psi}\right) \\
1.6 \%\end{array}$ \\
\hline
\end{tabular}

for $\mathrm{ZrC}$

\begin{tabular}{|c|c|c|c|c|c|}
\hline Young's modulus - Con. & Shear modulus & \multicolumn{2}{|c|}{ Poisson's ratio } & \multicolumn{2}{|c|}{ Bulk modulus } \\
\hline$E_{f o}$ & $G$ & $\mu_{l}$ & $\mu \rho \omega$ & $K_{l}$ & $K_{/ \omega}$ \\
\hline $\begin{array}{l}3870 \text { kilobars } \\
\left(56.13 \times 10^{6} \mathrm{psi}\right)\end{array}$ & $\begin{array}{l}1540 \text { kilobars } \\
\left(22.34 \times 10^{6} \mathrm{psi}\right)\end{array}$ & & 0.260 & & $\begin{array}{l}2688 \text { kilobars } \\
\left(38.99 \times 10^{8} \mathrm{psi}\right)\end{array}$ \\
\hline $\begin{array}{l}3119 \pm 503 \text { kilobars } \\
\left(45.24 \pm 7.30 \times 10^{6} \mathrm{psi}\right) \\
1.8 \%\end{array}$ & $\begin{array}{l}1223 \pm 40 \text { kilobars } \\
\left(17.74 \pm 0.58 \times 10^{6} \mathrm{psi}\right) \\
0.4 \%\end{array}$ & & $\begin{array}{l}0.245 \pm 0.170 \\
7.7 \%\end{array}$ & & $\begin{array}{l}1999 \pm 82 \text { kilobars } \\
\left(31.27 \pm 1.19 \times 10^{8} \mathrm{psi}\right) \\
9.8 \%\end{array}$ \\
\hline $\begin{array}{l}3249 \pm 51 \text { kilobars } \\
\left(47.12 \pm 0.74 \times 10^{8} \mathrm{psi}\right) \\
1.0 \%\end{array}$ & $\begin{array}{l}1280 \pm 27 \text { kilobars } \\
\left(18.56 \pm 0.39 \times 10^{6} \mathrm{psi}\right) \\
1.3 \%\end{array}$ & & $\begin{array}{l}0.258 \pm 0.005 \\
1.2 \%\end{array}$ & & $\begin{array}{l}2206 \pm 115 \text { kilobars } \\
\left(32.00 \pm 1.67 \times 10^{6} \mathrm{psi}\right) \\
3.3 \%\end{array}$ \\
\hline $\begin{array}{l}3291 \pm 15 \text { kilobars } \\
\left(47.73 \pm 0.22 \times 10^{8} \mathrm{psi}\right) \\
0.3 \%\end{array}$ & $\begin{array}{l}1317 \pm 7 \text { kilobars } \\
\left(19.10 \pm 0.10 \times 10^{6} \mathrm{psi}\right) \\
0.3 \%\end{array}$ & & $\begin{array}{l}0.245 \pm 0.010 \\
2.5 \%\end{array}$ & & $\begin{array}{l}2156 \pm 82 \text { kilobars } \\
\left(31.27 \pm 1.19 \times 10^{6} \mathrm{ps}\right) \\
2.4 \%\end{array}$ \\
\hline $\begin{array}{l}3063 \pm 45 \text { kilobars } \\
\left(44.43 \pm 0.65 \times 10^{8} \mathrm{psi}\right) \\
1.2 \%\end{array}$ & $\begin{array}{l}1165 \pm 31 \text { kilobars } \\
\left(16.90 \pm 0.45 \times 10^{8} \text { psi }\right) \\
2.2 \%\end{array}$ & & $\begin{array}{l}0.271 \pm 0.008 \\
2.4 \%\end{array}$ & & $\begin{array}{l}2136 \pm 68 \text { kilobars } \\
\left(30.98 \pm 0.99 \times 10^{6} \mathrm{psi}\right) \\
2.6 \%\end{array}$ \\
\hline $\begin{array}{l}2995 \pm 59 \text { kilobars } \\
\left(43.44 \pm 0.86 \times 10^{8} \mathrm{psi}\right) \\
1.2 \%\end{array}$ & $\begin{array}{l}1149 \pm 35 \text { kilobars } \\
\left(16.66 \pm 0.51 \times 10^{6} \mathrm{psi}\right) \\
1.9 \%\end{array}$ & & $\begin{array}{l}0.258 \pm 0.003 \\
0.7 \%\end{array}$ & & $\begin{array}{l}2009 \pm 78 \text { kilobars } \\
\left(29.14 \pm 1.13 \times 10^{8} \mathrm{psl}\right) \\
2.5 \%\end{array}$ \\
\hline $\begin{array}{l}317 \delta \pm 95 \text { kilobars } \\
\left(46.09 \pm 1.38 \times 10^{6} \mathrm{psi}\right) \\
6.4 \%\end{array}$ & $\begin{array}{l}1240 \pm 46 \text { kilobars } \\
\left(17.98 \pm 0.67 \times 10^{8} \mathrm{psi}\right) \\
8.0 \%\end{array}$ & & $\begin{array}{l}0.257 \pm 0.005 \\
4.5 \%\end{array}$ & & $\begin{array}{l}2142 \pm 76 \text { kilobars } \\
\left(31.07 \pm 1.10 \times 10^{6} \mathrm{psi}\right) \\
7.6 \%\end{array}$ \\
\hline
\end{tabular}


T'ABLE 23.

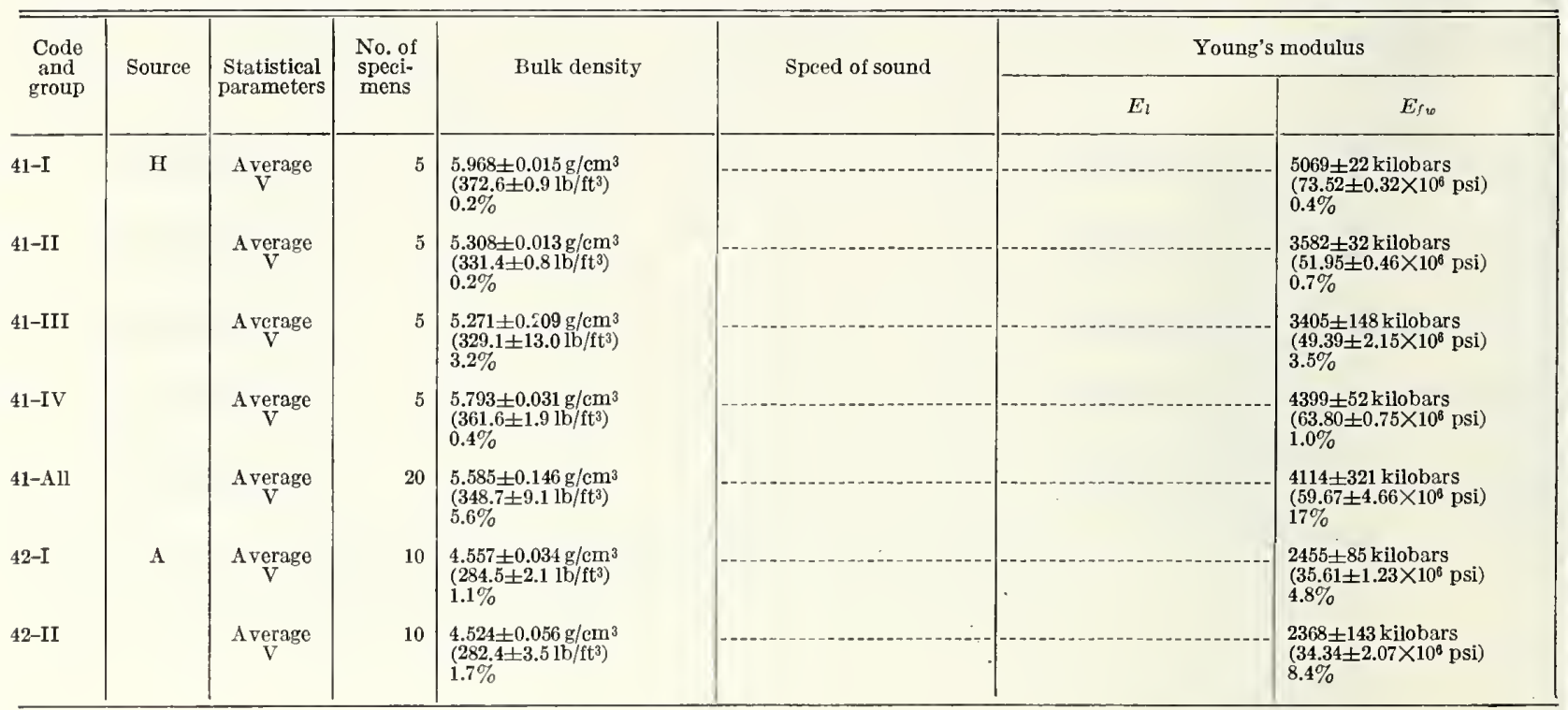

TABLE 23a. Statistical data for the analysis

\begin{tabular}{|c|c|c|c|c|c|c|}
\hline \multirow{3}{*}{ Code } & \multirow{3}{*}{ Compared groups } & \multirow{3}{*}{$\underset{\text { value }}{\text { Critical }}$} & \multicolumn{4}{|c|}{$F$ and $t$ values for } \\
\hline & & & \multirow{2}{*}{$\begin{array}{c}\text { Bulk } \\
\text { density }\end{array}$} & \multirow{2}{*}{$\begin{array}{l}\text { Speed of } \\
\text { sound }\end{array}$} & \multicolumn{2}{|c|}{ Young's modulus } \\
\hline & & & & & $E_{l}$ & $E_{f \omega}$ \\
\hline \multirow[t]{2}{*}{42} & $\begin{array}{l}F \text {-test } \\
\text { I and II }\end{array}$ & 4. 03 & 2. 68 & & 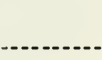 & 2.82 \\
\hline & $t$-test I and II & 2. 10 & 0.93 & & & 0.97 \\
\hline
\end{tabular}

a Underlined figures indicate that a significant difference does exist between the compared groups.

TABle 24. Data

\begin{tabular}{|c|c|c|c|c|c|c|c|}
\hline \multirow{2}{*}{$\begin{array}{l}\text { Code } \\
\text { and } \\
\text { group }\end{array}$} & \multirow{2}{*}{ Source } & \multirow{2}{*}{$\begin{array}{l}\text { Statistical } \\
\text { parameters }\end{array}$} & \multirow{2}{*}{$\begin{array}{l}\text { No. of } \\
\text { speci- } \\
\text { mens }\end{array}$} & \multirow{2}{*}{ Bulk density } & \multirow{2}{*}{ Speed of sound } & \multicolumn{2}{|c|}{ Young's modulus } \\
\hline & & & & & & $E_{l}$ & $F_{f \omega}$ \\
\hline $39-\mathrm{I}$ & $\mathrm{H}$ & $\begin{array}{c}\text { A verage } \\
\mathrm{V}\end{array}$ & 4 & $\begin{array}{l}5.987 \pm 0.072 \mathrm{~g} / \mathrm{cm}^{3} \\
\left(373.8 \pm 4.5 \mathrm{lb} / \mathrm{ft}^{3}\right) \\
0.8 \%\end{array}$ & & & $\begin{array}{l}3815 \pm 106 \text { kilobars } \\
\left(55.33 \pm 1.54 \times 10^{6} \mathrm{psi}\right) \\
1.8 \%\end{array}$ \\
\hline $39-$ II & & $\begin{array}{c}\text { Average } \\
\mathrm{V}\end{array}$ & 5 & $\begin{array}{l}5.874 \pm 0.300 \mathrm{~g} / \mathrm{cm}^{3} \\
\left(366.7 \pm 18.7 \mathrm{lb} / \mathrm{ft}^{3}\right) \\
4.1 \%\end{array}$ & & & $\begin{array}{l}3664 \pm 125 \text { kilobars } \\
\left(53.14 \pm 1.81 \times 10^{6} \mathrm{psi}\right) \\
2.8 \%\end{array}$ \\
\hline 39-III & & A verage & 1 & $\begin{array}{l}5.974 \mathrm{~g} / \mathrm{cm}^{3} \\
\left(372.9 \mathrm{lb} / \mathrm{ft}^{3}\right)\end{array}$ & & & $\begin{array}{l}3839 \text { kilobars } \\
\left(55.68 \times 10^{6} \mathrm{psi}\right)\end{array}$ \\
\hline $39-\mathrm{IV}$ & & $\begin{array}{c}\text { Average } \\
\mathrm{V}\end{array}$ & 4 & $\begin{array}{l}6.041 \pm 0.022 \mathrm{~g} / \mathrm{cm}^{3} \\
\left(377.1 \pm 1.4 \mathrm{lb} / \mathrm{ft}^{3}\right) \\
0.2 \%\end{array}$ & & & $\begin{array}{l}3886 \pm 18 \text { kilobars } \\
\left(56.36 \pm 0.26 \times 10^{6} \mathrm{psi}\right) \\
0.3 \%\end{array}$ \\
\hline $39-\mathrm{V}$ & & $\begin{array}{c}\text { Average } \\
\mathrm{V}\end{array}$ & 2 & $\begin{array}{l}5.966 \pm 0.485 \mathrm{~g} / \mathrm{cm}^{3} \\
\left(372.4 \pm 30.3 \mathrm{lb} / \mathrm{ft}^{3}\right) \\
0.9 \%\end{array}$ & & & $\begin{array}{l}3807 \pm 596 \text { kilobars } \\
\left(55.22 \pm 8.64 \times 10^{6} \mathrm{psi}\right) \\
1.7 \%\end{array}$ \\
\hline $39-I V$ & & $\begin{array}{c}\text { A verage } \\
\mathrm{V}\end{array}$ & 3 & $\begin{array}{l}5.991 \pm 0.008 \mathrm{~g} / \mathrm{cm}^{3} \\
\left(374.0 \pm 0.5 \mathrm{lb} / \mathrm{ft}^{3}\right) \\
0.1 \%\end{array}$ & & & $\begin{array}{l}3839 \pm 19 \text { kilobars } \\
\left(55.68 \pm 0.28 \times 10^{6} \mathrm{psi}\right) \\
0.2 \%\end{array}$ \\
\hline 39-All & & $\begin{array}{c}\text { A verage } \\
\text { V }\end{array}$ & 19 & $\begin{array}{l}5.966 \pm 0.038 \mathrm{~g} / \mathrm{cm}^{3} \\
\left(372.4 \pm 2.4 \mathrm{lb} / \mathrm{ft}^{3}\right) \\
1.3 \%\end{array}$ & & & $\begin{array}{l}3795 \pm 49 \text { kilobars } \\
\left(55.04 \pm 0.71 \times 10^{6} \mathrm{psi}\right) \\
2.7 \%\end{array}$ \\
\hline
\end{tabular}


Data for $\mathrm{ZrB}_{2}$

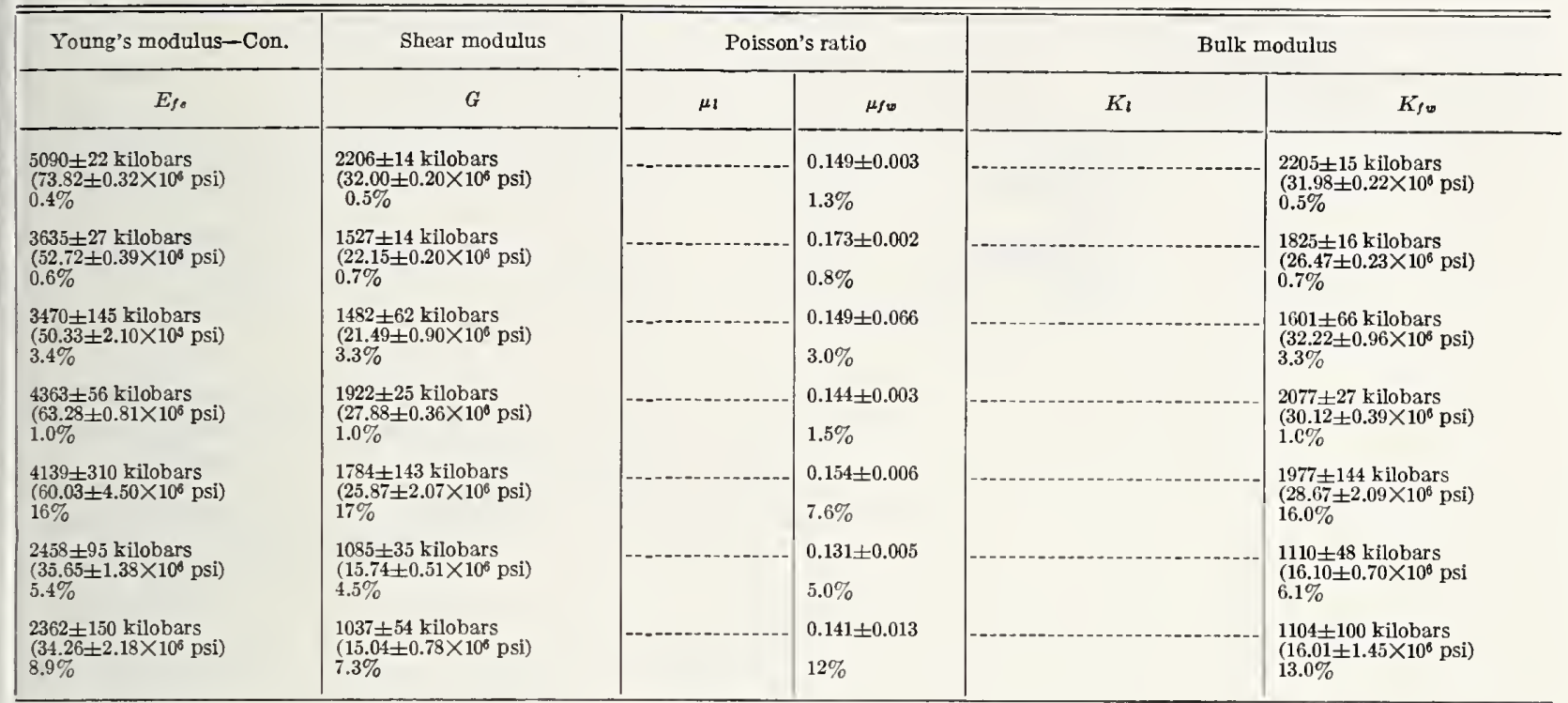

of values given in table 23

\begin{tabular}{|c|c|c|c|c|c|}
\hline \multicolumn{6}{|c|}{$F$ and $t$ values for-Continued } \\
\hline $\begin{array}{l}\text { Young's } \\
\text { modulus- } \\
\text { Continued }\end{array}$ & $\begin{array}{l}\text { Shear } \\
\text { modulus }\end{array}$ & \multicolumn{2}{|c|}{ Poisson's ratio } & \multicolumn{2}{|c|}{ Bulk modulus } \\
\hline$E_{\text {fe }}$ & $G$ & $\mu_{l}$ & $\mu_{f \varphi}$ & $K_{l}$ & $K_{f u}$ \\
\hline 2.51 & 2.36 & & a 7.04 & $---\infty$ & 4. 32 \\
\hline 1.00 & 1. 37 & & & & 0.13 \\
\hline
\end{tabular}

for $\mathrm{MoSi}_{2}$

\begin{tabular}{|c|c|c|c|c|c|}
\hline Young's modulus & Shear modulus & \multicolumn{2}{|c|}{ Poisson's ratio } & \multicolumn{2}{|c|}{ Bulk modulus } \\
\hline$E_{\text {fo }}$ & $G$ & $\mu l$ & 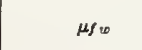 & $K_{\imath}$ & $K_{f w}$ \\
\hline $\begin{array}{l}3805 \pm 67 \text { kilobars } \\
\left(55.19 \pm 0.97 \times 10^{6} \mathrm{psi}\right) \\
1.1 \%\end{array}$ & $\begin{array}{l}1636 \pm 49 \text { kilobars } \\
\left(23.73 \pm 0.71 \times 10^{6} \mathrm{psi}\right) \\
1.9 \%\end{array}$ & & $\begin{array}{l}0.166 \pm 0.005 \\
1.7 \%\end{array}$ & & $\begin{array}{l}1910 \pm 51 \text { kilobars } \\
\left(27.70 \pm 0.74 \times 10^{6} \mathrm{psi}\right) \\
1.7 \%\end{array}$ \\
\hline $\begin{array}{l}3754 \pm 46 \text { kilobars } \\
\left(54.45 \pm 0.67 \times 10^{6} \mathrm{psi}\right) \\
1.0 \%\end{array}$ & $\begin{array}{l}1582 \pm 44 \text { kilobars } \\
\left(22.95 \pm 0.64 \times 10^{\theta} \mathrm{psi}\right) \\
2.2 \%\end{array}$ & & $\begin{array}{l}0.158 \pm 0.008 \\
4.1 \%\end{array}$ & & $\begin{array}{l}1790 \pm 102 \text { kilobars } \\
\left(25.96 \pm 1.48 \times 10^{6} \mathrm{psi}\right) \\
4.6 \%\end{array}$ \\
\hline $\begin{array}{l}3807 \text { kilobars } \\
\left(55.22 \times 10^{8} \mathrm{psi}\right)\end{array}$ & $\begin{array}{l}1638 \text { kilobars } \\
\left(23.76 \times 10^{6} \mathrm{psi}\right)\end{array}$ & & 0.172 & & $\begin{array}{l}\text { 1931 kilobars } \\
\left(28.01 \times 10^{6} \mathrm{psi}\right)\end{array}$ \\
\hline $\begin{array}{l}3866 \pm 13 \text { kilobars } \\
\left(56.07 \pm 0.19 \times 10^{6} \mathrm{psi}\right) \\
0.2 \%\end{array}$ & $\begin{array}{l}1665 \pm 10 \text { kilobars } \\
\left(24.15 \pm 0.15 \times 10^{8} \mathrm{psi}\right) \\
0.4 \%\end{array}$ & & $\begin{array}{l}0.167 \pm 0.005 \\
2.0 \%\end{array}$ & & $\begin{array}{l}1935 \pm 23 \text { kilobars } \\
\left(28.06 \pm 0.33 \times 10^{6} \mathrm{psi}\right) \\
0.8 \%\end{array}$ \\
\hline $\begin{array}{l}3798 \pm 377 \text { kilobars } \\
\left(55.09 \pm 5.47 \times 10^{8} \mathrm{psi}\right) \\
1.1 \%\end{array}$ & $\begin{array}{l}1628 \pm 272 \text { kilobars } \\
\left(23.61 \pm 3.95 \times 10^{6} \mathrm{psi}\right) \\
1.9 \%\end{array}$ & & $\begin{array}{l}0.169 \pm 0.013 \\
0.8 \%\end{array}$ & & $\begin{array}{l}1920 \pm 324 \text { kilobars } \\
\left(27.85 \pm 0.46 \times 10^{6} \mathrm{psi}\right) \\
3.9 \%\end{array}$ \\
\hline $\begin{array}{l}3804 \pm 5 \text { kilobars } \\
\left(55.17 \pm 0.07 \times 10^{6} \mathrm{psi}\right) \\
0.1 \%\end{array}$ & $\begin{array}{l}1648 \pm 6 \text { kilobars } \\
\left(23.90 \pm 0.09 \times 10^{6} \mathrm{psi}\right) \\
0.1 \%\end{array}$ & & $\begin{array}{l}0.165 \pm 0.006 \\
1.5 \%\end{array}$ & & $\begin{array}{l}1918 \pm 48 \text { kilobars } \\
\left(27.82 \pm 0.70 \times 10^{6} \mathrm{psi}\right) \\
1.0 \%\end{array}$ \\
\hline $\begin{array}{l}3804 \pm 23 \text { kilobars } \\
\left(55.17 \pm 0.33 \times 10^{6} \mathrm{psi}\right) \\
1.2 \%\end{array}$ & $\begin{array}{l}1629 \pm 19 \text { kilobars } \\
\left(23.63 \pm 0.28 \times 10^{6} \mathrm{psi}\right) \\
2.4 \%\end{array}$ & & $\begin{array}{l}0.165 \pm 0.003 \\
3.4 \%\end{array}$ & & $\begin{array}{l}1887 \pm 36 \text { kilobars } \\
\left(27.37 \pm 0.52 \times 10^{6} \mathrm{psi}\right) \\
3.9 \%\end{array}$ \\
\hline
\end{tabular}


TABle 25. Data

\begin{tabular}{|c|c|c|c|c|c|c|c|}
\hline \multirow{2}{*}{$\begin{array}{l}\text { Code } \\
\text { and } \\
\text { group }\end{array}$} & \multirow{2}{*}{ Source } & \multirow{2}{*}{$\begin{array}{l}\text { Statistical } \\
\text { parameters }\end{array}$} & \multirow{2}{*}{$\begin{array}{l}\text { No. of } \\
\text { speci: } \\
\text { mens }\end{array}$} & \multirow{2}{*}{ Bulk density } & \multirow{2}{*}{ Speed of sound } & \multicolumn{2}{|c|}{ Young's modulus } \\
\hline & & & & & & $F_{t}$ & $F_{f w}$ \\
\hline $40-\mathrm{I}$ & $A$ & $\begin{array}{c}\text { Average } \\
\mathrm{V}\end{array}$ & 10 & $\begin{array}{l}5.763 \pm 0.024{\mathrm{~g} / \mathrm{cm}^{3}}^{3} \\
\left(359.8 \pm 1.5 \mathrm{lb} / \mathrm{ft}^{3}\right) \\
0.6 \%\end{array}$ & & & $\begin{array}{l}1817 \pm 48 \text { kilobars } \\
\left(26.35 \pm 0.70 \times 10^{8} \mathrm{psi}\right) \\
3.5 \%\end{array}$ \\
\hline $40-I I$ & & $\begin{array}{c}\text { Average } \\
\mathrm{V}\end{array}$ & 4 & $\begin{array}{l}5.656 \pm 0.213 \mathrm{~g} / \mathrm{cm}^{3} \\
\left(353.1 \pm 13.3 \mathrm{lb} / \mathrm{ft}^{3}\right) \\
2.4 \%\end{array}$ & & & $\begin{array}{l}1760 \pm 62 \text { kilobars } \\
\left(25.53 \pm 0.90 \times 10^{8} \mathrm{psi}\right) \\
2.2 \%\end{array}$ \\
\hline
\end{tabular}

TABLE 25a. Statistical data for the

\begin{tabular}{|c|c|c|c|c|c|c|}
\hline \multirow{3}{*}{ Code } & \multirow{3}{*}{ Compared groups } & \multirow{3}{*}{$\begin{array}{c}\text { Critical } \\
\text { value }\end{array}$} & \multicolumn{4}{|c|}{$F$ and $t$ values for- } \\
\hline & & & \multirow{2}{*}{$\underset{\text { density }}{\text { Bulk }}$} & \multirow{2}{*}{$\begin{array}{l}\text { Speed of } \\
\text { sound }\end{array}$} & \multicolumn{2}{|c|}{ Young's modulus } \\
\hline & & & & & $E_{t}$ & $E_{f w}$ \\
\hline 40 & $\begin{array}{l}F \text {-test: } \\
\text { I and II } \\
t \text {-test: } \\
\text { I and II }\end{array}$ & 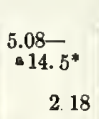 & ${ }^{b} \underline{15.3}$ & & & $\begin{array}{r}2.92 \\
1.58\end{array}$ \\
\hline
\end{tabular}

s $F$ and $t$ values marked with an asterisk indicate comparison with the critica value similarly marked.

$b$ Underlined figures indicate that a significant difierence does exist between the compared groups. 


\begin{tabular}{|c|c|c|c|c|c|}
\hline Young's modulus & Shear modulus & \multicolumn{2}{|c|}{ Poisson's ratio } & \multicolumn{2}{|c|}{ Bulk modulus } \\
\hline$F_{f o}$ & $G$ & $\mu l$ & $\mu_{f \omega}$ & $K_{l}$ & $K_{f w}$ \\
\hline $\begin{array}{l}1786 \pm 43 \text { kilobars } \\
\left(25.90 \pm 0.62 \times 10^{6} \mathrm{psi}\right) \\
3.4 \%\end{array}$ & $\begin{array}{l}723 \pm 33 \text { kilobars } \\
\left(10.49 \pm 0.48 \times 10^{6} \mathrm{psi}\right) \\
6.4 \%\end{array}$ & & $\begin{array}{l}0.261 \pm 0.040 \\
21 \%\end{array}$ & & $\begin{array}{l}1320 \pm 177 \text { kilobars } \\
\left(19.15 \pm 2.57 \times 10^{6} \mathrm{psi}\right) \\
19 \%\end{array}$ \\
\hline $\begin{array}{l}1737 \pm 194 \text { kilobars } \\
\left(25.19 \pm 2.81 \times 10^{8} \mathrm{psi}\right) \\
7.0 \%\end{array}$ & $\begin{array}{l}695 \pm 8 \text { kilobars } \\
\left(10.08 \pm 0.12 \times 10^{8} \mathrm{psi}\right) \\
0.7 \%\end{array}$ & & $\begin{array}{l}0.265 \pm 0.039 \\
9.2 \%\end{array}$ & & $\begin{array}{l}1260 \pm 254 \text { kilobars } \\
\left(18.27 \pm 3.68 \times 10^{6} \mathrm{psi}\right) \\
13 \%\end{array}$ \\
\hline
\end{tabular}

analysis of values given in table 25

\begin{tabular}{|c|c|c|c|c|c|}
\hline & & \multicolumn{4}{|c|}{$F$ and $t$ values for- } \\
\hline Young's & Shear modu- & \multicolumn{2}{|c|}{ Poisson's ratio } & \multicolumn{2}{|c|}{ Bulk modulus } \\
\hline$F_{\rho}$ & $G$ & $\mu l$ & $\mu f v$ & $K_{l}$ & $K_{f \infty}$ \\
\hline 4.12 & $* 82.2$ & & *5. 23 & & $*^{*} 2.40$ \\
\hline 1.03 & & & 0.14 & & 0.45 \\
\hline
\end{tabular}

\section{References}

[1] High temperature technology edited by I. E. Campbell, p. 29 (John Wiley \& Sons, Inc., New York, N.Y., 1956).

[2] W. R. Sheridan, The use of refractory ceramics in rocket engines, Bull. Am. Ceram. Soc. 37 [2] 91 (1958).

[3] S. Spinner, Elastic moduli of glasses by a dynamic method, J. Am. Ceram. Soc. 37 [5] 229 (1954).

[4] F. B. Hornibrook, Application of sonic method to freezing and thawing studies of concrete, ASTM Bull. No. 101, p. 6 (Dec. 1939).

[5] J. M. Ide, Some dynamic methods of determination of Young's modulus, Rev. Sci. Instr. 6 [10] 296 (1935).

[6] W. G. Cady, Piezoelectricity, p. 102, 1st ed. (McGrawHill Book Co., Inc., New York, N.Y., 1946).

[7] G. Pickett, Equations for computing elastic constants from flexural and torsional resonant frequencies of vibration of prisms and cylinders, ASTM Proc. 45, 846 (1945)

[8] ASTM book of standards, part 3, p. 1355 (C215-55T) (1955).

[9] R. J. Roark, Formulas for stress and strain, 2d ed, p. 154 (McGraw-Hill Book Co., Inc., New York, N.Y., 1938).

[10] S. Spinner, and R. C. Valore, Jr., Comparison of theoretical and empirical relations between the shear modulus and torsional resonance frequencies for bars of rectangular cross section, J. Research NBS 60 [5] 459 (1958) RP2861.

[11] S. M. Lang, R. S. Roth, and C. L. Fillmore, Some properties of beryllia and zirconia with titania, ceria and chromia, J. Research NBS 53 [4] 201 (1954) RP2534.

[12] S. M. Lang and F. P. Knudsen, Some physical properties of high-density thorium dioxide, J. Am. Ceram. Soc. 39 [12] 415 (1956).
[13] R. L. Coble and W. D. Kingery, Effect of porosity on physical properties of sintered alumina, J. Am. Ceram. Soc. 39 [11] 377 (1956).

[14] IT. Konopicky, Beitrag zur Untersuchung des Diagramms $\mathrm{Al}_{2} \mathrm{O}_{3}-\mathrm{SiO}_{2}$, Berichte der Technischeu, Komission und des Forschungs-Institute der Feuerfest Industrie, Berichte 22 (1957).

[15] Otto Ruff and Fritz Ebert, Z. anorg. Chem. 180, 19 (1929). Also U.S. Patent 1,969,099.

[16] R. F. Geller and P.J. Yavorsky, Effects of some oxide additions on the thermal length changes of zirconia, J. Research NBS 35, 87 (1945) RP1662.

[17] L. S. Ramsdell and J. A. Kohn, Developments in silicon carbide research, Acta Cryst. 5, part 2, p. 215 (March 1952).

[18] L. E. Mong and W. L. Pendergast, Dynamic and static tests for mechanical properties of fired plastic refractories and other more resilient materials, J. Am. Ceram. Soc. 39 [9] 301 (1956).

[19] L. E. Mong and D. M. Adelman, Control of factors affecting reproducibility of mechanical properties of refractory semidry press specimens, J. Am. Ceram. Soc. 41 [7] 267 (1958).

[20] R. S. Roth (private communication).

[21] J. M. Frankland and H. L. Whittemore, Test of cellular sheet-steel flooring, J. Research NBS 9, 131 (1932) RP463.

[22] W. J. Youden, Statistical methods for chemists, (John Wiley \& Sons, Inc., New York, N.Y., 1951).

[23] Wilfred J. Dixon and Frank J. Massey, Jr., Introduction to statistical analysis (McGraw-Hill Book Co., Inc., New York, N.Y. 1951).

WASHINGTON, D. C., July 28, 1958 


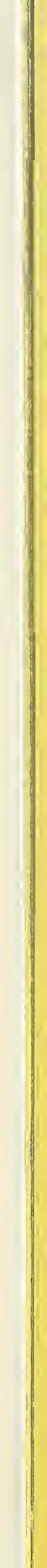




\section{THE NATIONAL BUREAU OF STANDARDS}

The scope of activities of the National Bureau of Standards at its major laboratories in Washington D.C., and Boulder, Colorado, is suggested in the following listing of the divisions and sections engaged in technical work. In general, each section carries out specialized research, development, and engineering in the field indicated by its title. A brief description of the activities, and of the resultant publications, appears on the inside of the front cover.

WASHINGTON, D.C.

Electricity and Electronics. Resistance and Reactance. Electron Devices. Electrical Instruments. Magnetic Measurements. Dielectrics. Engineering Electronics. Electronic Instrumentation. Electrochemistry.

Optics and Metrology. Photometry and Colorimetry. Optical Instruments. Photographic Technology. Length. Engineering Metrology.

Heat. Temperature Physics. Thermodynamics. Cryogenic Physics. Rheology. Molecular Kinetics. Free Radicals Research.

Atomic and Radiation Physics. Spectroscopy. Radiometry. Mass Spectrometry. Solid State Physics. Electron Physics. Atomic Physics. Neutron Physics. Radiation Theory. Radioactivity. X-ray. High Energy Radiation. Nucleonic Instrumentation. Radiological Equipment. Chemistry. Organic Coatings. Surface Chemistry. Organic Chemistry. Analytical Chemistry. Inorganic Chemistry. Electrodeposition. Molecular Structure and Properties of Gases. Physical Chemistry. Thermochemistry. Spectrochemistry. Pure Substances.

Mechanics. Sound. Mechanical Instruments. Fluid Mechanics. Engineering Mechanics. Mass and Scale. Capacity, Density, and Fluid Meters. Combustion Controls.

Organic and Fibrous Materials. Rubber. Textiles. Paper. Leather. Testing and Specifications. Polymer Structure. Plastics. Dental Research.

Metallurgy. Thermal Metallurgy. Chemical Metallurgy. Mechanical Metallurgy. Corrosion. Metal Physics.

Mineral Products. Engineering Ceramics. Glass. Refractories. Enameled Metals. Constitution and Microstructure.

Building Technology. Structural Engineering. Fire Protection. Air Conditioning, Heating, and Refrigeration. Floor, Roof, and Wall Coverings. Codes and Safety Standards. Heat Transfer. Concreting Materials.

Applied Mathematics. Numerical Analysis Computation. Statistical Engineering. Mathematical Physics.

Data Processing Systems. SEAC Engineering Group. Components and Techniques. Digital Circuitry. Digital Systems. Analog Systems. Applications Engineering.

- Office of Basic Instrumentation.

- Office of Weights and Measures.

BOULDER, COLORADO

Cryogenic Engineering. Cryogenic Equipment. Cryogenic Processes. Properties of Materials. Gas Liquefaction.

Radio Propagation Physics. Upper Atmosphere Research. Ionosphere Research. Regular Prediction Services. Sun-Earth Relationships. VHF Research. Radio Warning Services. Airglow and Aurora. Radio Astronomy and Arctic Propagation.

Radio Propagation Engineering. Data Reduction Instrumentation. Radio Noise. Tropospheric Measurements. Tropospheric Analysis. Propagation-Terrain Effects. Radio-Meteorology. Lower Atmospheric Physics.

Radio Standards. High-Frequency Electrical Standards. Radio Broadcast Service. Radio and Microwave Materials. Electronic Calibration Center. Microwave Circuit Standards.

Radio Communication and Systems. Low Frequency and Very Low Frequency Research. High Frequency and Very High Frequency Research. Modulation Systems. Antenna Research. Navigation Systems. Systems Analysis. Field Operations. 
